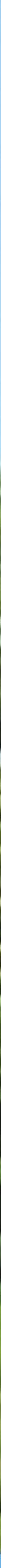

Programmeringsstudie Smart Technology in Agro-Horti-Water-Food 



\section{Programmeringsstudie Smart Technology in Agro-Horti-Water-Food}

Auteurs: N.J.J.P. Koenderink, J.L. Top, P. Goethals, A. Nieuwenhuizen

Instituut: Wageningen Research

Dit onderzoek is uitgevoerd door Wageningen Food \& Biobased Research in opdracht van Topsectoren A\&F, T\&U en Water en gefinancierd door het Ministerie van Landbouw, natuur en voedselkwaliteit, in het kader van Programmeringsstudie-uitvraag t.b.v. KIA topsectoren A\&F, T\&U, Water (projectnummer 6234172900).

Wageningen Food \& Biobased Research

Wageningen, mei 2019

Openbaar

Rapport 1955

ISBN 978-94-6343-945-9 
Versie: definitief

Reviewer: Henk Wensink

Goedgekeurd door: Henk Wensink

Opdrachtgever: Topsectoren A\&F, T\&U en Water

Financier: het Ministerie van Landbouw, natuur en voedselkwaliteit

Reviewer: Henk Wensink, WFBR

Dit rapport is gratis te downloaden op https://doi.org/10.18174/478487/ of op www.wur.nl/wfbr (onder publicaties).

(C) 2019 Wageningen Food \& Biobased Research, instituut binnen de rechtspersoon Stichting Wageningen Research.

Het is de opdrachtgever toegestaan dit rapport integraal openbaar te maken en ter inzage te geven aan derden. Zonder voorafgaande schriftelijke toestemming van Wageningen Food \& Biobased Research is het niet toegestaan:

a. dit door Wageningen Food \& Biobased Research uitgebrachte rapport gedeeltelijk te publiceren of op andere wijze gedeeltelijk openbaar te maken;

b. dit door Wageningen Food \& Biobased Research uitgebrachte rapport, c.q. de naam van het rapport of Wageningen Food \& Biobased Research, geheel of gedeeltelijk te doen gebruiken ten behoeve van het instellen van claims, voor het voeren van gerechtelijke procedures, voor reclame of antireclame en ten behoeve van werving in meer algemene zin;

c. de naam van Wageningen Food \& Biobased Research te gebruiken in andere zin dan als auteur van dit rapport.

Postbus 17, 6700 AA Wageningen, T 03174800 84, E info.wfbr@wur.nl, www.wur.nl/wfbr. Wageningen Food \& Biobased Research is onderdeel van Wageningen University \& Research.

Alle rechten voorbehouden. Niets uit deze uitgave mag worden verveelvoudigd, opgeslagen in een geautomatiseerd gegevensbestand of openbaar gemaakt in enige vorm of op enige wijze, hetzij elektronisch, hetzij mechanisch, door fotokopieën, opnamen of enige andere manier, zonder voorafgaande schriftelijke toestemming van de uitgever. De uitgever aanvaardt geen aansprakelijkheid voor eventuele fouten of onvolkomenheden. 


\section{Inhoud}

Inhoud

Woord vooraf

Samenvatting

1. Inleiding

$\begin{array}{llr}\text { 2. Overzicht maatschappelijke opgave } & 14\end{array}$

2.1 Sustainable Development Goals $\quad 14$

$\begin{array}{ll}2.2 \text { LWV-missies } & 15\end{array}$

$\begin{array}{ll}2.3 \text { Conclusie maatschappelijke opgave } & 19\end{array}$

$\begin{array}{lr}\text { 3. Beschrijving lopend onderzoek } & 20\end{array}$

$\begin{array}{lll}3.1 & \text { Wereldwijde top } 5 \text { instituten op technologisch vlak } & 20\end{array}$

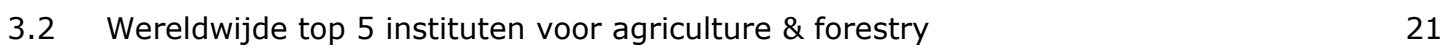

$\begin{array}{lll}3.3 & \text { Het Nederlandse onderzoekslandschap } & 24\end{array}$

3.3.1 Smart Technology in Agro-Horti-Water-Food aan de Nederlandse universiteiten 24

3.3.2 Smart Technology in Agro-Horti-Water-Food aan de Nederlandse hogescholen 26

3.3.3 Smart Technology in Agro-Horti-Water-Food aan de Nederlandse onderzoeksinstituten $\quad 26$

3.3.4 Smart Technology in Agro-Horti-Water-Food in samenwerkingsverbanden 27

3.4 Lopende projecten op het gebied Smart Technology in Agro-Horti-Water-Food 29

3.4.1 Lopende projecten gefinancierd door de topsectoren A\&F, T\&U en Water 29

$\begin{array}{lll}3.4 .2 & \text { Lopende projecten gefinancierd door de EU } & 31\end{array}$

3.4.3 Lopende projecten gefinancierd vanuit de kennisbasisprogramma's 31

4. Witte vlekken analyse $\quad 34$

4.1 Kennis- en innovatieopgaven smart technology onderwerpen 35

4.2 Technologie-toepassingen in het lopend onderzoek $\quad 39$

$\begin{array}{lll}4.3 & \text { Technologische trendanalyses } & 43\end{array}$

4.3.1 Technologische trends volgens Gartner $\quad 43$

4.3.2 De potentie van robotisering volgens ING Bank 44

4.3.3 Tech-trends volgens Accenture $\quad 44$

4.3.4 Tech-trends volgens Deloitte $\quad 45$

$\begin{array}{lll}4.3 .5 & \text { Conclusie } & 46\end{array}$

$\begin{array}{llr}\text { 5. Interesse bedrijfsleven } & 48\end{array}$

$\begin{array}{lr}\text { 6. Programmeringsadvies } & \mathbf{5 0}\end{array}$

$\begin{array}{lll}6.1 & \text { Afbakening } & 50\end{array}$

6.2 Missie-doorsnijdende 'Smart Technology' in Agro-Horti-Water-Food 50

6.2.1 Smart Technology op meer gedetailleerde schaal $\quad 50$

6.2.2 Geavanceerde robots en dedicated mens-machine-interactie voor optimale beslissingen 52

6.3 Missie-gedreven 'Smart Technology' in Agro-Horti-Water-Food 55

$\begin{array}{lll}6.4 & \text { Conclusie } & 55\end{array}$

Bijlage A: Overzicht sleuteltechnologieën $\quad 57$

$\begin{array}{ll}\text { Bijlage B: Lopende projecten gefinancierd door de topsectoren } & 58\end{array}$ 


\section{Woord vooraf}

Het rapport wat voor $u$ ligt is het resultaat van een opdracht om een programmeringsstudie uit te voeren op het onderwerp 'Smart Technology in Agro-Horti-Water-Food'. Dit is een van de technologieonderwerpen gedefinieerd door de topsectoren A\&F, T\&U en Water.

De programmeringsstudie is uitgevoerd in opdracht van de drie topsectoren A\&F, T\&U en Water en is gefinancierd door het ministerie van Landbouw, natuur en voedselkwaliteit. De opdracht was om een zelfstandig leesbaar rapport op te leveren dat 'Smart Technology in Agro-Horti-Water-Food' beschouwt vanuit de maatschappelijke opgaven die aan ons voorliggen, een overzicht geeft van het lopend onderzoek op dit onderwerp, een witte vlekkenanalyse uitvoert, de interesse van het bedrijfsleven toetst, en tot slot een programmeringsadvies geeft. Ook is gevraagd een MMIP (meerjarig, missiegedreven innovatieprogramma) op te leveren waarin het programmeringsadvies is uitgewerkt.

Deze programmeringsstudie is een van de acht studies die in opdracht zijn gegeven aan Wageningen Research. Alle acht studies dienen als input voor de drie topsectoren in het opstellen van hun Kennisen Innovatieagenda.

De programmeringsstudie is onafhankelijk uitgevoerd door de auteurs met input van een groot aantal anderen. We willen dan ook onze dank uitspreken aan de volgende mensen (op alfabetische volgorde), die elk hun steentje hebben bijgedragen aan het tot stand komen van dit rapport: Wilfred Appelman, Victor de Boer, Peter Bonants, Simone van der Burg, Michel Haring, Silke Hemming, Geerten Hengeveld, Jeroen Hoekendijk, Chantal Hukkelhoven, Anne Hummelen, Sander Janssen, Corné Kempenaar, Willem Jan Knibbe, Andries Koops, Ben Langelaan, Kees Lokhorst, Marcel van Haren, Martijn Noort, Marcel Paalman, Erik Pekkeriet, Sander Peters, Sanne Stroosnijder, Roel Veerkamp, Jan Verschoor, Liselotte de Vries, Ron Wehrens, Edo Wissink, Sjaak Wolfert en Rick van de Zedde.

Daarnaast zijn we dankbaar aan allen die hun input hebben geleverd via de enquête om de interesse vanuit het bedrijfsleven te polsen. Zonder deze input zou hoofdstuk 5 niet tot stand zijn gekomen.

Tot slot willen we José Vogelezang, Gertjan Fonk, Onno Moller, Rutger Oorsprong, Frans Lips en bedanken voor het kritisch lezen van de stukken. José in het bijzonder is gedurende het gehele traject een sparringpartner geweest vanuit de opdrachtgever.

Het rapport is als zelfstandig leesbaar stuk opgeleverd. Het is bedoeld voor eenieder die geïnteresseerd is in het onderwerp 'Smart Technology in Agro-Horti-Water-Food' en de stand van het onderzoek anno 2019.

Nicole Koenderink, Jan Top, Paul Goethals, Ard Nieuwenhuizen

Wageningen, 31 mei 2019 


\section{Samenvatting}

\section{Opdracht}

Deze programmeringsstudie is uitgevoerd op verzoek van de topsectoren A\&F, T\&U en Water en is gefinancierd door het Ministerie van Landbouw, Natuur en Voedselkwaliteit. De opdracht was om in een openbaar en zelfstandig leesbaar rapport in kaart te brengen wat er op het gebied van Smart Technology in het Agro-Horti-Water-Food domein aan maatschappelijke opgave is, wat het lopend onderzoek is, waar de witte vlekken zitten en in hoeverre het bedrijfsleven geïnteresseerd is in smart technology toepassingen in de praktijk. Op basis van deze informatie is de auteurs gevraagd om met een advies te komen voor programmering op het gebied van Smart Technology in Agro-Horti-Water-Food binnen de kennis- en innovatieagenda Landbouw, Water en Voedsel (KIA LWV) voor de komende vijf jaar. In dit rapport vindt $u$ de uitwerking van deze programmeringsstudie. De rapportage is via onafhankelijk onderzoek tot stand gekomen.

\section{Context}

In de studie bespreken we de ontwikkelingen op het gebied van 'Smart Technology in Agro-Horti-WaterFood'. Hiermee doelen we op onderwerpen die betrekking hebben op het raakvlak tussen de digitale wereld en de fysieke wereld (hoofdstuk 1). Smart Technology maakt gebruik van de Sense - Think Act cyclus. Dit omvat het volledige systeem van data-acquisitie via sensoren en vanuit andere bronnen, data-analyse, modellering, interpretatie, beslissingsondersteuning en robotica. Daarmee kan de slimme technologie in de agro-horti-water-food keten worden ingezet om zowel bedrijfsmatige doelstellingen als de grote maatschappelijke uitdagingen zoals in hoofdstuk 2 beschreven het hoofd te bieden.

\section{Maatschappelijke opgave}

Nederland staat, met de rest van de wereld, voor een aantal grote maatschappelijke opgaven rond voedselproductie, klimaatverandering en duurzaam gebruik en beheer van grote wateren. Deze zijn wereldwijd geformuleerd in de Sustainable Development Goals en vinden voor het thema Landbouw, Water, Voedsel (LWV) hun weerslag (grotendeels) in de zes missies zoals door het ministerie gedefinieerd.

De LWV-missies zijn geformuleerd vanuit het Agro-Horti-Water-Food domein en de problematiek die in dat domein moet worden opgelost. De ambities geformuleerd in de LWV-missies zijn groot. De potentiële toepassingen, reikwijdte en impact van 'smart technologies' in het Agro-Horti-Water-Food domein is breed. Dat zorgt ervoor dat er overal aanknopingspunten zitten om de ontwikkeling op 'smart technology' gebied zo te richten dat ze bijdraagt aan de ambitieuze missies.

\section{Lopend onderzoek}

De beschrijving van het lopend onderzoek is via een aantal verschillende kanten bekeken. Ten eerste door het wereldwijde wetenschappelijk landschap in kaart te brengen, vervolgens door ons te richten op het Nederlandse landschap. We brengen in kaart wat de 4 TU's doen op het gebied van 'Smart Technology' in het landbouw-, water- \& voedingdomein en bespreken ook relevante faculteiten van algemene universiteiten. We sluiten de inventarisatie af met relevante onderzoeksagenda's van de hogescholen en van (virtuele) samenwerkingsverbanden.

Het laatste deel van de inventarisatie van het lopende onderzoek richt zich op de lopende projecten gefinancierd vanuit de topsectoren A\&F, T\&U en Water, op relevante projecten uit het H2020programma van de EU en op kennisbasis-onderzoek waarin Smart Technology een rol speelt.

\section{Interesse bedrijfsleven}

Via een enquête is de interesse van het bedrijfsleven in Smart Technology in Agro-Horti-Water-Food gepeild. Wat opvalt is dat de respondenten de meerwaarde van smart technology zien en verwachten dat deze nog hoger wordt. Dit past bij het agile karakter van smart technology: als een onderzoek resulteert in een innovatie, dan is de innovatie vaak het begin van grotere innovaties in het verlengde. Zo ontstaan een onderzoek - ontwikkeling - implementatie-cyclus, waarin partijen steeds verdere smart technology ontwikkelingen implementeren in hun dagelijkse bedrijfsvoering. 


\section{Het programmeringsadvies}

De impact van Smart Technology in Agro-Horti-Water-Food context is enorm. Ontwikkelingen gaan razendsnel en systeemveranderingen als gevolg van 'smart technologies' zijn groot. Wereldwijd vindt er veel onderzoek plaats, zowel op het gebied van Smart Technology als op het gebied van Agro-HortiWater-Food.

We zijn van mening dat het ontwikkelen en toepassen van Smart Technology in het Agro-Horti-WaterFood domein zinvol is bij het realiseren van de ambitieuze LWV-missies. We adviseren om een missiedoorsnijdende MMIP te programmeren binnen de KIA LWV met zwaartepunt op twee deelprogramma's:

1. Smart Technology voor meten, beslissen en handelen op meer gedetailleerde schaal: van veld naar plot, van kas naar plant, van groep naar dier, van batch naar product, van watervoorziening naar leidingsegment, van bevolkingsgroep naar individu. Hiervoor moeten kennis- en innovatieopgaven op de gebieden sensoren, niet-destructieve en niet-invasieve meetmethoden, decision support systemen, autonome robots en digital twins worden opgepakt.

2. Geavanceerde robots en dedicated mens-machine-interactie voor optimale beslissingen: de essentie van dit deelprogramma is dat er nieuwe kennis nodig is om mensmachine-ecosystemen op te zetten, waarin de sterke punten van mensen (creativiteit, flexibiliteit, context-awareness) en machines (logisch redeneren, 24/7 online, mogelijkheid om veel data te behappen) met elkaar gecombineerd worden voor het maken van optimale beslissingen ten behoeve van de LWV-missies.

Daarnaast is het essentieel om ook het direct toepasbare onderzoek op de verschillende missiegerelateerde onderwerpen te (blijven) financieren, zodat ook op deze toepassingsgebieden technologische voortgang plaatsvindt. De innovatie-opgaven hiervoor zijn in paragraaf 4.2 uitgewerkt. Dat helpt om de concurrentiepositie van Nederland te behouden en te werken aan de maatschappelijke opgaven.

Vervolgens is het onze overtuiging dat 'Smart Technology in Agro-Horti-Water-Food' vraagt om continue aandacht op het gebied van data-infrastructuur. Als het beheer van data niet op orde is, wordt het realiseren van de potentie van Smart Technology een stuk moeilijker en inefficiënter. Dit kan de sector zich niet veroorloven. Daarom adviseren we ook om in onderzoek, ontwikkeling en uitrol te investeren om de data-infrastructuur in het domein in goede banen te leiden.

Tot slot zijn 'societal en economic concerns' belangrijke randvoorwaardelijke zaken voor de cross-over van 'Smart Technology' in Agro-Horti-Water-Food. De impact van robotisering en digitalisering op het welbevinden van mens en dier is een factor die belangrijk is. Juist door naar de totale implicaties te kijken van de introductie van nieuwe technologie, wordt maatschappelijke acceptatie ingebed in de ontwikkeling.

Met deze randvoorwaardelijke zaken afgedekt en met voldoende aandacht voor de data-infrastructuur in de sector, bieden de twee genoemde missie-doorsnijdende onderwerpen en de missie-gerelateerde toepassingsgebieden voldoende uitdaging én potentie voor het realiseren van concrete bijdragen aan de ambitieuze doelen gesteld in de LWV-missies voor de komende vijf jaar. 


\section{Inleiding}

In deze programmeringsstudie bespreken we de ontwikkelingen op het gebied van 'Smart Technology in Agro-Horti-Water-Food'. Hiermee doelen we op onderwerpen die betrekking hebben op het raakvlak tussen de digitale wereld en de fysieke wereld. Daarmee omvat het het sleuteltechnologiecluster Digitale Technologie, en delen van de sleuteltechnologieclusters Fotonica \& Lichttechnologie, Ontwikkel- \& Fabricagetechnologie, Nanotechnologie, en Life sciences en biotechnologie (zie Bijlage A voor een overzicht van de sleuteltechnologieën en clusters). Geavanceerde materialen is een onderwerp dat belangrijk is voor het Agro-Horti-Water-Food domein maar dat niet past bij 'Smart Technology' zoals gedefinieerd in deze studie. Dit onderwerp kan in de kennis- en innovatieagenda (KIA) van landbouwwater-voedsel (LWV) een plek krijgen in bijv. missie B, en kan ook in de KIA sleuteltechnologieën afgedekt worden via een MJP (meerjarenprogramma) over smart materialen.

De afgelopen decennia is data- en informatietechnologie in opkomst. Waar het vijfentwintig jaar geleden nog niet vanzelfsprekend was om een computer te gebruiken in de agro-horti-water-food keten, is het tegenwoordig heel gebruikelijk om robots, sensoren en slimme algoritmes te benutten om allerlei processen te optimaliseren. De kracht van data- en ICT-systemen ten opzichte van de mens zit in het bijna onbeperkte geheugen, onbeperkt logisch doorredeneren, en onbeperkte beschikbaarheid (24/7).

In de gehele keten is veel data geautomatiseerd beschikbaar gekomen door de inzet van sensoren en data-acquisitietechnieken. Daarnaast zijn er veel historische data beschikbaar in teksten, spreadsheets en databases. Deze data kunnen geautomatiseerd worden geanalyseerd en geïnterpreteerd. Algoritmes kunnen verbanden blootleggen, beslissingen onderbouwen, risico's inschatten, en redeneertaken uitvoeren voor de mens. Machines, robots en andere actuatoren kunnen acties uitvoeren in de keten, waarbij de kennis verkregen uit data en modellen gecombineerd met expertkennis en menselijke intuïtie een belangrijke rol speelt. Dit geheel vatten we samen onder de noemer Smart Technology. Smart Technology maakt gebruik van de Sense - Think - Act cyclus, zoals in Figuur 1 afgebeeld. Dit omvat het volledige systeem van data-acquisitie via sensoren en vanuit andere bronnen, data-analyse, modellering, interpretatie, beslissingsondersteuning en robotica. Daarmee kan de slimme technologie in de agro-horti-water-food keten en het onderliggende watersysteem worden ingezet om zowel bedrijfsmatige doelstellingen als de grote maatschappelijke uitdagingen zoals in hoofdstuk 2 beschreven het hoofd te bieden.

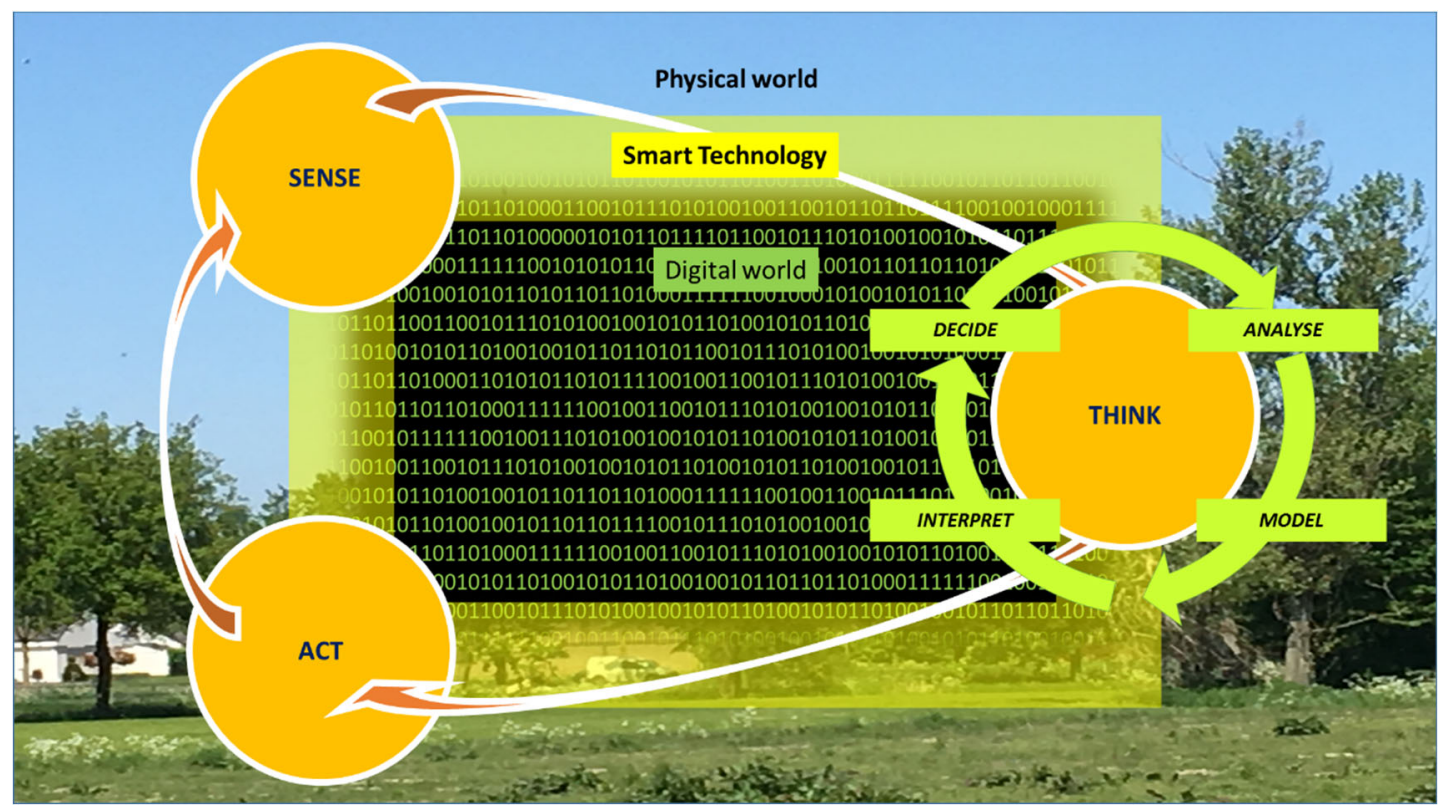

Figuur 1: Schematisch overzicht van de interactie tussen het fysieke en het digitale domein. Het domein van smart technology bevindt zich op het raakvlak van beide werelden en opereert in een sense - think - act cyclus. Daarmee omvat het het sleuteltechnologiecluster Digitale Technologie, en delen van de sleuteltechnologieclusters Fotonica \& Lichttechnologie, Ontwikkel- \& Fabricagetechnologie en Nanotechnologie. 
'Smart Techology in Agro-Horti-Water-Food' omvat een groot aantal technologische onderwerpen. De komende jaren raken deze onderwerpen steeds meer vervlochten; ze worden op nieuwe wijzen gecombineerd en samengevoegd. Artificial Intelligence (AI) raakt verder ontwikkeld. Autonome en AIgebaseerde analyse en beslissystemen zullen leren omgaan met expert input, humane kennis, intuïtie en logica om zo nieuwe data in nieuwe situaties te kunnen interpreteren en behandelen. Deze technologische ontwikkelingen dragen bij aan oplossingen voor het agro-horti-water-food domein.

Voor we beschrijven voor welke maatschappelijke opgaven we als Nederland staan en hoe 'Smart Technology for Agro-Horti-Water-Food' daaraan gekoppeld is, is het goed om het containerbegrip 'smart technology' wat te preciseren.

Smart technology omvat allerlei concepten (hardware, software en orgware) die gezamenlijk ervoor zorgen dat de sense - think - act cyclus doorlopen kan worden. Het vakgebied 'smart technology in agro-horti-water-food' wordt op dit moment grotendeels gekarakteriseerd door:

- Robots: robots zijn machines die in meer of mindere mate intelligent zijn. Ze werken veelal volgens het volledige kort-cyclische sense - think - act paradigma. Robots worden veel ingezet in situaties waarin werk repetitief is, waar mogelijk meer snelheid en precisie te behalen is, arbeidskrachten niet beschikbaar zijn, menselijke arbeid te duur of te onvoorspelbaar is, of arbeidsomstandigheden voor mensen onaangenaam zijn (te koud, te gevaarlijk).

- Sensoren: in de gehele agro-food keten worden steeds meer sensoren toegepast om data te verzamelen over de toestand van een product, proces of hun omgeving. Veel voorkomende toepassingen zijn kwaliteitsbewaking, herkomstinformatie, precisielandbouw, optimalisatie van processing in de food industry, optimalisatie van de supply chain, transparantie in agrifood ketens. Voorbeelden van sensoren zijn temperatuurloggers, camera's, NIR-sensoren, lab-on-a-chip, wearables, biochemische sensoren. Wireless sensoren en smart sensoren zijn bezig aan een opmars in de gehele keten van teelt tot en met consument. Een sensor is smart wanneer deze zelfstandig meet, data opslaat, processen kan aansturen en communiceren met een host.

- Decision Support: een belangrijk doel van 'Smart Technology for Agro-Horti-Water-Food' is om beslissingen te nemen gebaseerd op relevante data. Decision support vindt plaats in het kort-cyclische think-gedeelte van het sense-think-act paradigma. Hierbij worden verkregen data geschoond, geharmoniseerd en geanalyseerd, wordt expert kennis en ervaring of statistische kennis gebruikt om de data te modelleren, te interpreteren en er informatie van te maken, en wordt op basis van de context van het systeem een beslissing genomen. Lang-cyclisch worden de gemaakte

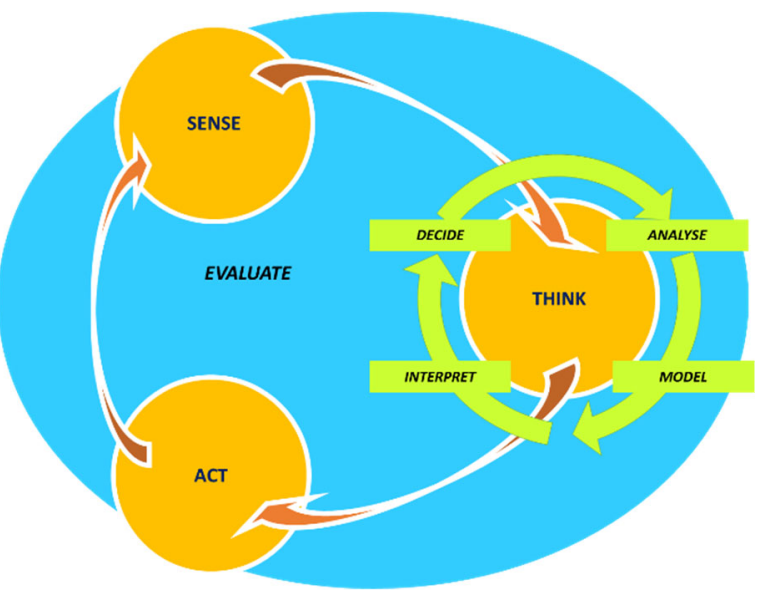
beslissingen geëvalueerd en wordt kennis aangepast om toekomstige beslissingen beter te laten zijn, ook dit is een vorm van beslisondersteuning. Decision support komt op verschillende niveaus voor: operationeel waarbij directe machinesturing, operator advisering, keurmeesterondersteuning plaats vindt, tactisch waarbij dag/weekplanningen en rapporten worden gemaakt op basis van geaggregeerde procesinformatie, strategisch waarbij investeringsbeslissingen e.d. worden ondersteund op basis van de verzamelde informatie en gemaakte analyses.

- Artificial Intelligence (AI): het concept kunstmatige intelligentie komt oorspronkelijk voort uit de gedachte dat menselijke intelligentie nagebootst kan worden door geavanceerde software. De huidige opvatting is dat machine-intelligentie complementair is aan menselijke intelligentie. Een belangrijk element van AI is dat de software kan leren. Hoewel het leren uit (big) data het meest in beeld is, omvat AI ook het leren van expliciete kennis via experts en uit documenten. Waar machine learning (inclusief deep learning) zich richt op het automatisch herkennen van patronen in data, is kennisacquisitie een manier om concepten en kennisregels te digitaliseren. Machine leren is vooral 
effectief voor het doorgronden van ongestructureerde data, zoals beelden en geluid. Kennisacquisitie is vooral nuttig als de kennis al geordend is. Om de voordelen van beide werkwijzen te combineren werkt men tegenwoordig toe naar hybride AI, waaronder Explainable AI (XAI), zodat het van uit data geleerde modellen ook duidelijk is op welke redenering ze gebaseerd zijn. Dit is ook een antwoord op de ethische vraag hoe we AI-oplossingen verantwoording kunnen laten afleggen over de genomen beslissingen.

- Big data: big data is een verzamelnaam voor grote hoeveelheden data. Kenmerkend voor big data is onder andere dat het voorkomt uit het combineren van meerdere, verschillende databronnen met gestructureerde data (bijv. numerieke data, spectrale data, etc.), maar ook ongestructureerde data (documenten, afbeeldingen, etc.). Big data kunnen vaak niet meer in gangbare datamanagementsystemen verwerkt worden en gaan sowieso het menselijke bevattingsvermogen te boven. Om uit de snelgroeiende hoeveelheid databronnen toch bruikbare informatie te kunnen halen, zijn specifieke softwaretools ontwikkeld. Deze maken gebruik van kunstmatige intelligentie om trends en patronen op te sporen en slim te filteren. Voorbeelden van big data toepassingen zijn het analyseren van real-time beelden uit camera's en andere sensoren voor autonome navigatie van (landbouw)voertuigen of het filteren van 'trending topics' uit miljoenen Twitter berichten. Een aspect van big data dat vaak onvoldoende onderkend wordt is dat niet de omvang van een dataset maar de kwaliteit ervan doorslaggevend is voor de waarde ervan. Dan gaat het om kwaliteit in de zin van betrouwbaarheid, accuraatheid en duidelijkheid gegeven een bepaalde toepassing.

- Sequencing Technology: Met behulp van next generation sequencing (NGS) technologie kan snel de DNA- of RNA-sequentie van een monster bepaald worden. Vervolgens kan met behulp van software analyse snel bepaald worden, welke organismen in het monster aanwezig zijn (track and trace) en wat ze doen (functionele analyse) om zo een snel advies te kunnen geven voor voedselzekerheid en voedselveiligheid. Deze techniek genereert 'Big Data'.

- Blockchain: Blockchain is een relatief nieuw principe om data op een veilige manier te registreren én te delen met belanghebbenden in bijvoorbeeld agro-food ketens. Waar in gangbare systemen data vaak op één plek opgeslagen worden (bijvoorbeeld in een lokale database) waarop centrale beveiliging toegepast wordt (zowel fysiek als elektronisch), werkt Blockchain met (vele) identieke kopieën van dataverzamelingen verspreid over het internet. Elke toevoeging of mutatie van data in een dataverzameling wordt meteen in elke kopie geregistreerd als een nieuwe transactie in een soort digitaal grootboek. Daarmee ontstaat een ketting van transacties die onderling verbonden zijn die niet verbroken kan worden. Door gebruik van Blockchain kan op deze manier transparantie en vertrouwen bij gebruikers in agro-food ketens ontstaan waar tot nu toe instituties zoals banken of andere intermediairs nodig waren om dat te borgen. Voorbeelden van Blockchain toepassingen zijn het betalen met digitale munten zoals Bitcoin, maar ook keteninformatiesystemen voor het registreren van bijvoorbeeld teelt, verwerking, transport en handel in agrarische producten, waardoor beter inzicht ontstaat in productiewijze, herkomst en alle handelstransacties voor een voedselproduct tot en met de consument.

- Internet of Things: deze term wordt gebruikt om aan te geven dat steeds meer sensoren, apparaten en gebruiksvoorwerpen direct gekoppeld worden aan het internet. Via het internet wisselen ze direct data uit met andere gekoppelde apparaten en met andere gebruikers. Met deze input kan men allerlei processen geautomatiseerd en real-time besturen, met of zonder tussenkomst van mensen. Hiervoor moet het netwerk snel veel data kunnen verwerken. Privacy is ook een issue, omdat er steeds meer apparaten in de thuisomgeving gekoppeld worden aan het

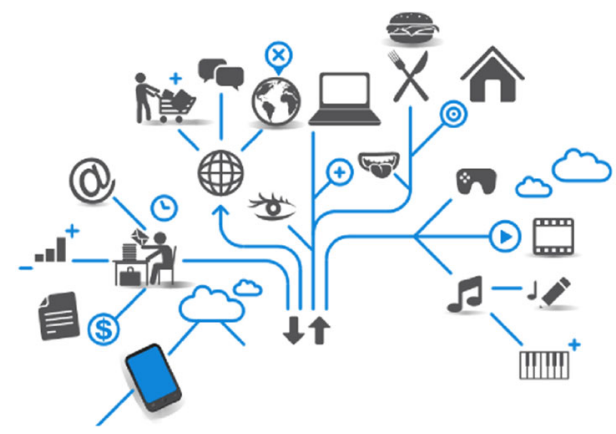

Figuur 2: Schematische weergave van internet of things (Bron: http://www.datamining4u.nI). internet, maar ook omdat van mensen in de publieke omgeving steeds meer vastgelegd wordt. Denk aan observatiecamera's en allerlei elektronische pasjes waarin we digitale 'sporen' achterlaten. 
Voorbeelden van Internet of Things zijn o.a. slimme koelkasten die zelf bijhouden welke voorraad er nog is en eventueel zelfstandig (gezonde) bestellingen kunnen doen bij de supermarkt of gezonde recepten kunnen voorstellen. Een andere toepassing is het gebruik van bodemvochtsensoren die in de akkerbouw gebruikt worden om draadloos, real-time via internet, de vochttoestand van de bodem te kunnen monitoren.

- Digital twins: een Digital Twin is een digitale representatie (simulatiemodel) van een fysiek object, maar ook van een compleet proces of organisme (organen, planten, dieren en zelfs mensen). Een Digital Twin kan worden gebruikt in producten procesontwerp, real-time monitoring en bijvoorbeeld voor de voorspelling van de onderhoudsmomenten van apparaten. Digital Twins zijn inmiddels een belangrijk concept, mogelijk gekoppeld aan het Internet of Things (IoT). Voordeel van het

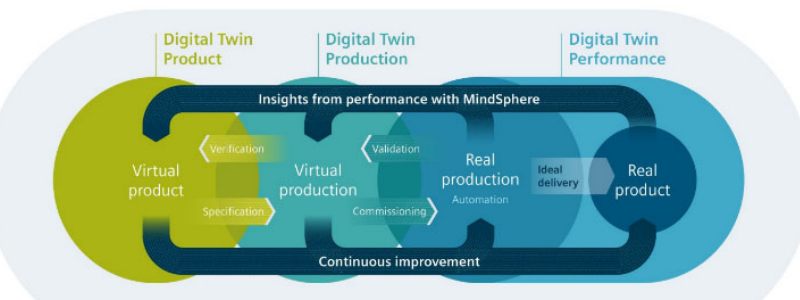

Figuur 3: Schematische weergave van digital twins bij het ontwerp en de monitoring van processen en producten (Bron: 'Mindsphere' van Siemens ) opzetten van een Digital Twin is dat een product of proces eerst volledig digitaal ontworpen én getest wordt alvorens het fysiek te bouwen. Hierdoor kan het gedrag onder allerlei (extreme) omstandigheden nauwkeurig bestudeerd en voorspeld worden. Wijzigingen in een digitaal ontwerp zijn gemakkelijker, sneller en tegen veel lagere kosten door te voeren dan in een fysiek ontwerp. Enkele voorbeelden van digital twins in het agrifood domein zijn het gebruik van digitale planten om (een digitale versie van) een plukrobot te testen en te trainen met behulp van deep learning, of een digital twin van een vriestunnel voor voorgebakken frites om het optimale ontwerp te maken én te testen voor deze fysiek gebouwd wordt.

- Connectivity: snelle breedbandverbindingen zijn nodig voor betrouwbare, efficiënte en robuuste uitwisseling van data, essentieel voor smart farming en smart agrifood ketens. Ondanks het feit dat er technische oplossingen zijn, die verschillen in capaciteit, energieverbruik, bereik en kosten, is er behoefte aan doorontwikkeling van digitale connectiviteit op maat voor het landbouwdomein. Denk aan gebieden op platteland waar de internetverbinding soms beperkingen heeft, maar waar er wel behoefte is om grote databestanden (dronebeeld van een gewas) snel en betrouwbaar te kunnen verzenden naar een farm managementsysteem of big data-analyse tool, en het vervolgens te kunnen gebruiken op een landbouwmachine of robot. De ontwikkeling van $5 G$ is in volle gang. Daarnaast is er behoefte aan brede toepassing van standaarden voor connectiviteit die deels nog in ontwikkeling zijn, en integratie van technische oplossingen en tools in een netwerk. Agrariërs geven regelmatig aan dat ze meer plug \& play oplossingen willen binnen precisielandbouw.

- Augmented Reality (AR) en Virtual Reality (VR) kan worden gezien als het toevoegen van informatie en beelden aan de realiteit zodat iemand de combinatie van realiteit en toegevoegde informatie ervaart als één werkelijkheid. AR kan dienen als een geavanceerd instructie- en begeleidingsinstrument. In industrieën met complexe processen zoals in de agrofood productie waarbij kleine fouten of afwijkingen aanzienlijke kosten met zich mee kunnen brengen of ernstige schade kunnen veroorzaken - kan dit van grote waarde zijn. Virtual Reality (VR) creëert een volledig nieuwe omgeving los van de bestaande omgeving waarin iemand zich bevindt. VR wordt vooral gebruikt in ontwerpprocessen, simulaties, games en trainingen. Het combineren van AR en VR leidt tot mixed reality. Die synchronisatie van werkelijkheid en toegevoegde informatie vormt een technologische uitdaging. AR lijkt heel futuristisch maar wordt al twintig jaar daadwerkelijk gebruikt.

- Drones of UAV's (unmanned aerial vehicles) zijn onbemande luchtvaartuigen. Wordt het toestel op afstand bestuurd, dan moet de bestuurder zich in de nabijheid bevinden, "in line of sight". Professionele drones kunnen soms ook voorgeprogrammeerd worden zodat ze een specifieke route volgen om een gebied te observeren. Drones worden het meest gebruikt voor aardobservaties, oftewel remote sensing waarnemingen. De drone is dan het platform en de camera's kunnen zeer divers zijn, afhankelijk van het doel. Drones vullen het gat tussen satellietwaarnemingen en 
waarnemingen op de grond. In korte tijd kunnen veel hectares geobserveerd worden. Drones kunnen ook een transportfunctie vervullen. Denk hierbij aan vergelijkbare toepassingen als kleine vliegtuigen voor het uitvoeren van gewasverzorging. Hiervoor zijn grotere versies van drones nodig. Naast drones voor in de lucht zijn er ook drones voor onbemande waarnemingen in het water. Toepassingen hiervan in de agrofoodcontext zijn nog beperkt, maar met opkomst van visteelt liggen hier ook mogelijkheden.

Buiten de landbouw zijn er ook autonome professionele drone-systemen waarbij vliegtuigen vanaf de andere kant van de wereld bestuurd kunnen worden. Voor de landbouw liggen hier mogelijk toepassingen in remote ondersteuning van bedrijven en/of het op afstand controleren van productkwaliteit en herkomstgarantie.

- 3D printing: 3D printing, oftewel Additive Manufacturing, is een nieuwe productietechniek waarmee op basis van een digitaal ontwerp een product laag voor laag wordt opgebouwd. De technologie biedt unieke mogelijkheden om op basis van digitale informatie, op een flexibele, decentrale wijze en 'on-demand' voedingsmiddelen te produceren. 3D printing vindt plaats in allerlei domeinen, waaronder het voedseldomein. Door ontwikkelingen op 3D food printing gebied, vindt ontkoppeling plaats van de productie van de grondstoffen en de productie van het uiteindelijke voedselproduct. Technologisch voordeel van 3D food printen is de gecontroleerde lokale depositie van verschillende materialen en structuren, waarmee nieuwe productfunctionaliteiten kunnen worden gecreëerd. De technologie biedt op termijn de mogelijkheid om gepersonaliseerde voeding te produceren op basis van de in toenemende mate beschikbare data van individuele consumenten, zoals genotype, fenotype, gedrag en voorkeuren, onder andere op basis van draagbare sensoren.

Alle bovenstaande technologieën hebben invloed op de (sociale) levens van mensen en de manier waarop ze zich verhouden tot natuur en dieren. Ze beïnvloeden de manier waarop mensen naar de wereld om hen heen kijken, hoe ze die ervaren en kennis vergaren. Ze bepalen de manier waarop mensen beslissen, handelingen kiezen, interacteren. Geautomatiseerde systemen nemen taken over en zorgen daarmee voor een hervorming en herverdeling van taken, verantwoordelijkheden en verwachtingen. Hoe kunnen we zorgen dat deze technologieën werkelijk bijdragen aan een verbetering van de kwaliteit van leven? Maatschappelijke implicaties van de verschillende toepassingen van technologische innovaties moeten zorgvuldig worden onderzocht, inclusief ethische implicaties. Een greep uit de catalogus van mogelijke ethische onderwerpen:

- Privacy: digitale technologieën genereren en verwerken data die persoonlijke informatie kunnen bevatten of inbreuk kunnen maken op de persoonlijke leefsfeer van individuen. Wat betekent privacy in het digitale tijdperk en hoe moeten we dit beschermen?

- Data eigendom en toegangsrechten tot data: er worden steeds meer data gegenereerd, geïnterpreteerd, opgeslagen en hergebruikt. Deze data bieden mogelijkheden om kennis te vergaren. Tegelijk vragen vele individuen zich af wat er met 'hun' data gebeurt. Wie bepaalt wat er met deze data mag gebeuren? Wie mag toegang hebben tot data? Wie mag profiteren van kennis die is gebaseerd op data? En onder welke voorwaarden?

- Dierenwelzijn: verschillende innovaties (zoals robots, IOT op boerderijen, sensoren) kunnen de taken van bijvoorbeeld boeren op boerderijen vergemakkelijken. Maar ze kunnen ook de relatie veranderen tussen mens en dier. Dat roept vragen op: (hoe) veranderen deze technologieën de mens-dier relatie? Kunnen deze technologieën dierenwelzijn verbeteren? Of leiden ze tot een verdere instrumentalisatie van dieren?

- Toerekeningsvatbaarheid: als mensen technologieën inzetten om zelfstandig taken te verrichten (zoals een autonome robot), of om adviezen te geven over de taken die mensen zelf verrichten, wie is er dan verantwoordelijk voor het resultaat? Dit is vooral een vraag als er door toedoen van een technologie een ongeluk wordt veroorzaakt. 
- Menselijkheid versus transhumaniteit: digitale technologieën geven de mogelijkheid om de grenzen van de menselijke ervaring en deliberatie op te rekken; zelflerende robots beschikken over menselijke eigenschappen. Wat betekent het om mens te zijn? Is er een wezenlijk verschil tussen onszelf en robots? 


\section{Overzicht maatschappelijke opgave}

Nederland staat, met de rest van de wereld, voor een aantal grote maatschappelijke opgaven rond voedselproductie, klimaatverandering en duurzaam gebruik en beheer van grote wateren. Deze zijn wereldwijd geformuleerd in de Sustainable Development Goals en vinden voor het thema Landbouw, Water, Voedsel (LWV) hun weerslag (grotendeels) in de zes missies zoals door het ministerie gedefinieerd.

In dit hoofdstuk van de programmeringsstudie 'Smart Technology for Agro-Horti-Water-Food' schetsen we de maatschappelijke opgave waar we voor staan en geven we aan hoe 'Smart Technology in AgroHorti-Water-Food' hierin een rol kan spelen. Dit doen we door eerst te kijken naar de maatschappelijke opgaven zoals vastgelegd in de sustainable development goals. Vervolgens bekijken we de missies in het LWV-domein zoals door het ministerie gedefinieerd. Tot slot vatten we de maatschappelijke opgave samen in paragraaf 2.3 .

\subsection{Sustainable Development Goals}

Voor we de link tussen 'Smart Technology' en de LWV-missies leggen, zoomen we uit naar het mondiale niveau. De wereld ziet zich geconfronteerd met grote uitdagingen op agro-food-water gebied: meer voedselproductie met minder inputs, in een circulair systeem, en robuust met betrekking tot klimaatverandering. Vijf belangrijke transities in de komende jaren zijn de eiwittransitie (de overgang naar meer plantaardige eiwitten), de transitie naar gezonde voeding (meer groente, fruit, noten, minder vlees en suiker), een transitie naar efficiënt grondstof- en energiegebruik in de food industry, minder voedselverspilling in de gehele keten, en de energietransitie van fossiel naar duurzaam.

De 193 lidstaten van de Verenigde Naties (VN) hebben een ontwikkelingsagenda voor 2015 - 2030 vastgesteld, bestaande uit 17 zogenaamde werelddoelen voor duurzame ontwikkeling (Sustainable Development Goals, SDG's). Voor deze programmeringsstudie zijn de volgende SDG's het meest van toepassing.

\section{SDG 2: Einde aan honger, zorgen voor voedselzekerheid en duurzame landbouw $\mathbf{1}^{\mathbf{1}}$}

In 2030 mag niemand op de wereld meer hongerlijden. Iedereen moet toegang hebben tot veilig, voedzaam en voldoende voedsel, het hele jaar door. Er moet dus nog veel gebeuren op het gebied van voedselzekerheid. In 2050 zal de wereldbevolking zijn toegenomen tot zeker negen miljard mensen. Daarom richt dit tweede doel zich ook op de voedselproductie. Zo moeten er in 2030 duurzame systemen zijn voor voedselproductie. Dit betekent dat de voedselproductie omhoog moet, zonder ecosystemen aan te tasten.

\section{SDG 6: Schoon water en sanitaire voorzieningen voor iedereen}

In doel zes is vastgesteld dat iedereen in 2030 toegang moet hebben tot schoon drinkwater. Ook moeten alle landen in 2030 een goed werkend waterbeheersysteem hebben.

\section{SDG 11: Maak steden veilig, veerkrachtig en duurzaam}

De helft van de wereldbevolking, zo'n 3.5 miljard mensen, woont in de stad. En de verwachting is dat dat aantal alleen maar toeneemt: in 2030 woont mogelijk bijna 60 procent van alle mensen wereldwijd in stedelijk gebied. Duurzame groei is de grootste uitdaging van de steden van de toekomst. Ondanks het grote aantal mensen dat in de steden woont, bedekken alle steden slechts drie procent van al het landoppervlakte. Toch kunnen de steden een groot verschil maken: ze zijn goed voor zo'n 60 - 80 procent van alle energieconsumptie en zo'n 75 procent van de carbon emissies. Tegelijkertijd heeft de hoge bevolkingsdichtheid in de stad ook voordelen. Zo is het gemakkelijker om bronnen efficiënter in te zetten; technologische innovaties breed door te voeren; en minder grondstoffen en energie te gebruiken.

\footnotetext{
${ }^{1}$ De samenvatting van de SDG doelen is in verkorte vorm overgenomen van de website

https://www.sdgnederland.nl/sdgs/doel-2-einde-aan-honger/, geraadpleegd op 27 april 2019.
} 


\section{SDG 12: Duurzame consumptie en productie}

Het produceren van onze goederen moet met het oog op de groeiende wereldbevolking veel handiger: 'meer produceren met minder'. Zo moet het gebruik van vervuilende energiebronnen teruggeschroefd, want ondanks de technologische vooruitgang zullen OESO-landen naar schatting nog 35 procent meer energie verbruiken in 2020. We moeten zorgen dat het kleine percentage aan drinkwater dat er is maar drie procent van de wereldwatervoorraad is zoet water - minder vaak vervuild en verspild wordt. Op het gebied van voedselproductie moet de verdeling beter. Terwijl er bijna 800 miljoen mensen honger hebben, is er in sommige delen van de wereld juist te veel (ongezond) eten, wat zorgt voor hart- en vaatziekten. Naar schatting haalt ongeveer een derde van wat de wereld produceert aan voedsel, ons bord niet. Het doel is om in 2030 voedselverspilling gehalveerd te hebben. Onze productie moet schoner: het doel is om chemicaliën en ander afval in de lucht, water en bodem te verminderen. De bedoeling is om de hele keten bewust te maken van de problemen en te laten meehelpen bij de oplossingen. Van boer tot supermarkt, tot gemeentes, waterbedrijven en uiteindelijk de consument.

\section{SDG 13: Aanpak klimaatverandering}

Ieder land op ieder continent heeft te maken met klimaatverandering. De opwarming van de aarde heeft nu al invloed op het dagelijks leven en het inkomen van miljoenen mensen wereldwijd en dat zal in de toekomst alleen maar toenemen. Droogte, overstromingen en extreme stormen komen vaker voor door klimaatverandering. Het is belangrijk dat landen maatregelen nemen om zich te wapenen tegen de gevolgen van klimaatverandering.

\section{SDG 14: Beschermen en duurzaam gebruik van de oceanen en zeeën}

Oceanen zijn met hun temperatuur, hun stromingen en hun onderzeese leven de motor van mondiale systemen die de aarde bewoonbaar maken voor mensen. Ze bedekken drie kwart van het aardoppervlak. Ons drinkwater, ons weer, klimaat, de kusten, veel van ons eten en zelfs de lucht die we inademen is afhankelijk van de zee. Zonder zorgvuldig beheer van deze essentiële mondiale hulpbron is er geen duurzame toekomst mogelijk.

\section{SDG 15: Beschermen van ecosystemen, bossen en biodiversiteit}

Bescherm, herstel en bevorder het duurzaam gebruik van ecosystemen, beheer bossen duurzaam, bestrijd woestijnvorming en landdegradatie en draai het terug en roep het verlies aan biodiversiteit een halt toe. In 2020 moet de ontbossing zijn gestopt en moet bebossing wereldwijd toenemen. In datzelfde jaar moeten zoetwater- en aardse ecosystemen beschermd worden, met name bossen, moerassen, berggebieden en steppen. In 2030 moet de woestijnvorming tegen worden gegaan.

\subsection{LWV-missies}

De LWV-missies zijn geformuleerd vanuit het Agro-Horti-Water-Food domein en de problematiek die in dat domein moet worden opgelost. Dwars op de missies zijn sleuteltechnologieën vastgesteld. Het is zinvol om de cross-over knooppunten te benoemen: waar en hoe zal 'Smart Technology' helpen de ambities uit de missies te realiseren? In deze paragraaf geven we per missie hiervoor een overzicht.

Missie A. Kringlooplandbouw -- De subthema's in deze missie vallen uiteen in twee soorten onderwerpen. Enerzijds zijn er drie subthema's (minder gebruik meststoffen en water; geen emissies naar grond- en oppervlaktewater; duurzame productie eiwitrijke grondstoffen) die vragen om precisielandbouw en AI in de kas. Deze subthema's hebben baat bij goede sensoren, standaardisatie van de verkregen data, big data principes als dataverzameling, datakwaliteit en data-analyse, decision support systemen, en afhankelijk van de geavanceerdheid van de oplossing spelen hier ook humancomputer-omgeving interactie, robotica, autonome meet- en regeltechnologie en artificial intelligence een rol. Anderzijds zijn er twee subthema's (hergebruik van zij- en reststromen; herstel en benutting biodiversiteit) die een systeembenadering vragen voor de keten in zijn geheel. Er moet een ketenoptimalisatie plaatsvinden, waarbij een integrale afweging gemaakt wordt en er verschillende doelen geformuleerd kunnen worden. Emissies naar lucht, bodem, grond- en oppervlaktewater moeten worden gereduceerd. Bovendien moet een heldere afweging worden gemaakt tussen economische belangen en biodiversiteit. 'Smart Technology' draagt bij door te werken aan big data (die o.a. door sensoren of vanuit open data-bronnen worden gegenereerd) te analyseren, de ketens te modelleren, via scenariostudies de impact van verschillende keuzes te kunnen doorrekenen, en op die manier 
beslissingsondersteuning te bieden. Mens-machine interactie (en machine-dier interactie) is essentieel om het systeem te doorgronden en goede beslissingen te maken.

Bij de optimalisatie van kringlooplandbouw worden grondstoffen en hulpstoffen (waaronder water) tijdens de teelt beter benut waardoor emissies naar bodem, grond- en oppervlaktewater worden gereduceerd. Vanuit 'Smart Technology in Agro-Horti-Water-Food' wordt hieraan bijgedragen door slimme zuiveringstechnologieën in combinatie met sensoren die productieprocessen en de kwaliteit van grond- en hulpstoffen monitoren, en die input leveren aan scenariostudies waarmee de impact van verschillende keuzes kan worden doorgerekend.

Vanuit 'Smart Technology in Agro-Horti-Water-Food' wordt dan ook bijgedragen aan deze missie, met name op de toepassingsgebieden precision farming, biodiversiteitsmonitoring, fenotypering, adaptive horticulture, autonome robots en smart water systems. Deze toepassingsgebieden hebben baat bij 'smart technology' in de vorm van goede sensoren, standaardisatie van de verkregen data, big data principes als dataverzameling, datakwaliteit en data-analyse, decision support systemen, nondestructieve metingen, en afhankelijk van de geavanceerdheid van de oplossing spelen hier ook humancomputer-omgeving interactie, robotica, autonome meet- en regeltechnologie en artificial intelligence een rol. Sleutelwoorden die hierbij horen vanuit 'Smart Technology' zijn dan ook sensoren, big data, standaardisatie, dataverzameling, datakwaliteit, FAIR-principes, data-analyse, robotica, autonome meet- en regeltechniek, decision support systeem, modelleren, human-computer interactie en kunstmatige intelligentie.

Deze toepassingsgebieden dragen bij aan optimaal grondstof- en hulpstofgebruik, energiebesparing in de keten, verhoging van productierendement, hogere productkwaliteit, betere afstemming vraag en aanbod, actieve benutting van natuurlijke productvariatie en terugdringen van food waste in de primaire productie door beter inzicht in en betere benutting van mogelijk gebruik van zij- en reststromen.

Missie B. Klimaatneutrale landbouw en voedselproductie -- De subthema's in deze missie belichten duurzaamheid bij de productie, zowel bij open teelt, glastuinbouw en veeteelt (emissiereductie in bodem- en landgebruik, duurzame veehouderij, duurzame glastuinbouw) en richten zich vervolgens op energiebesparing en CO2-reductie in de keten (energiebesparing en -productie in het rurale gebied, CO2 vastlegging en -gebruik). De eerste drie subthema's vragen om goed meten, analyseren en beslissen voor precisiebeslissingen; de laatste twee richten zich meer op scenariostudies en simulaties voor slimme systeemkeuzes.

Bij klimaatneutrale landbouw ligt het accent op het monitoren en track-en-tracing van greenhouse gasses. Hierbij wordt vanuit 'Smart Technology' bijgedragen door de big data die door sensoren of uit andere bronnen worden gegenereerd te analyseren, de planten/dieren/omgeving, de boerderijprocessen en de overige ketenschakels te modelleren, via scenariostudies de impact van verschillende keuzes te kunnen doorrekenen, en op die manier beslissingsondersteuning te bieden.

'Smart Technology' richt zich voor deze missie op de toepassingsgebieden precision farming, food waste prevention \& reduction, water-land-energy-food nexus, handling \& packaging, adaptive food processing, adaptive horticulture, autonome robots en smart water systems. Deze toepassingsgebieden vragen om input vanuit 'Smart Technology' in de vorm van sensoren om goed te kunnen meten, data-analyse methoden, expertkennis en beslissingsondersteuning voor precisiebeslissingen en herontwerp (bijv. DNA-informatie voor veredeling).

Qua voedselproductie vallen procesoptimalisatie en proces- en product-redesign met hightech middelen onder deze missie. Sleutelwoorden die hierbij horen zijn sensoren, dataverzameling, standaardisatie,

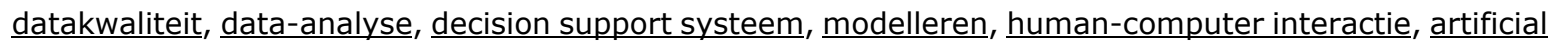
intelligence, autonome meet-en regeltechnologie en simulaties. 
Missie C. Klimaatbestendig landelijk en stedelijk gebied -- De LWV-missie Klimaatbestendig landelijk en stedelijk gebied is gedefinieerd als: "Nederland is in 2050 klimaatbestendig en waterrobuust." De subthema's richten zich op mitigerende maatregelen bij teveel of tekort aan water, en op een systeemverandering door de introductie van klimaatadaptieve landbouwsystemen. 'Smart Technology' draagt hieraan bij door big data te analyseren, de ketens te modelleren, via scenariostudies de impact van verschillende keuzes te kunnen doorrekenen, en op die manier beslissingsondersteuning te bieden.

Vanuit 'Smart Technology' wordt aan deze missie gewerkt op de toepassingsgebieden water-landenergy-food nexus (watermanagement, waterinfrastructuur, energiebesparing), 3D food printing, last mile/e-commerce, adaptive horticulture en smart water systems. Slimme en snelle detectiemethoden, zelflerende netwerken van sensors en soft sensors, alarmeringssystemen op basis van data mining algoritmes (zowel fore-casting als back-casting), zijn onmisbaar voor de veiligheid in de waterketen, zeker als deze meer, vaker decentraal en hoogwaardiger, geïntegreerd wordt in de circulaire economie. Ook voor slim en robuust onderhoud en beheer van de assets, voor decentrale aanpak van vervuilingsbronnen, voor verdergaande optimalisatie van de efficiëntie van het systeem, voor het mogelijk maken van communicatie-, mitigatie- en economische strategieën (bijvoorbeeld het principe van 'de vervuiler betaalt') zijn innovatieve technologieën voor monitoring en control essentieel. Sleutelwoorden die hierbij horen zijn modelleren, simulaties, sensoren, decision support systeem en big data. Hiervoor zal ook kunstmatig data gegenereerd moeten worden, ook een taak voor AI, om scenario's goed te parameteriseren.

Deze toepassingsgebieden dragen bij aan een klimaatbestendig en waterrobuust Nederland door op alle punten in het systeem optimale keuzes te maken, gebaseerd op real-time data, lange termijn trends en kennis van de aanwezige experts bijeengebracht via een decision support systeem. Hierdoor wordt het mogelijk om nieuwe verdienmodellen te introduceren en te optimaliseren, en weereffecten op de voedselproductie en leefomgeving te voorspellen, waardoor tijdige mitigerende maatregelen genomen kunnen worden.

Missie D. Gewaardeerd, gezond en veilig voedsel -- 'Smart Technology' speelt een rol in deze missie via de toepassingsgebieden food waste prevention \& reduction, non-destructieve kwaliteitsmetingen, biodiversiteitmonitoring, personalised nutrition, 3D food printing, last mile / ecommerce, trusted food supply chains, handling \& packaging, adaptive food processing en smart water systems. Sleutelwoorden die hierbij horen zijn sensoren, big data, blockchain, datakwaliteit, standaarden, human-computer interaction, ethical AI, artificial intelligence, modelleren, expertkennis, monitoring, dataficatie.

Deze onderwerpen dragen bij aan de missie gewaardeerd, gezond en veilig voedsel door op alle punten in het systeem de beschikbare data te kunnen interpreteren en te kunnen koppelen aan de behoeften van alle stakeholders. De consument wil lekker, gezond en veilig eten met aandacht voor dierenwelzijn en milieu. De keten kan inspelen op deze consumentenbehoefte door transparante informatie te bieden, deze te koppelen aan gepersonaliseerd voedingsadvies; door vroegtijdig in de keten te kunnen signaleren waar eventuele problemen zouden kunnen opduiken en daar extra te monitoren. Door de verhoogde ketensamenwerking, wordt het vanzelfsprekender om de kosten en baten eerlijker te verdelen. Wereldwijd staan we voor grote voedseltransities, nodig voor een gezonde en duurzame wereld. De consument zal meer groente, fruit en noten gaan eten en het dieet zal minder dierlijke en meer plantaardige eiwitten gaan bevatten in de komende jaren.

Qua ketenoptimalisatie ligt er ook een behoorlijk potentieel voor de voedingsmiddelenindustrie door op basis van betere informatie uit de voorliggende schakels uit de keten actiever gebruik te maken van de natuurlijke variatie in grondstoffen (verse producten, alternatieve eiwitbronnen). Als meer bekend is van een partij en herkomst, kan in daar in de processing van voedingsmiddelen actief gebruik van gemaakt worden (dynamische recepturen) zonder eerst alle ingrediënten met dure (extra) processen tot een standaard specificatie terug te moeten brengen. Hiervoor is betrouwbare keteninformatie nodig en is transparantie een belangrijk aspect. 
Qua fraude en voedselveiligheid kunnen op basis van online, real-time data-acquisitiesystemen voedselveiligheidsmodellen worden gevoed met een cloud-gebaseerde e-infrastructuur die risicobeoordelaars (industrie en autoriteiten) in staat stelt om zo vroeg mogelijk in de productieketen interventieacties uit te voeren.

Ook draagt 'Smart Technology in Agro-Horti-Water-Food' bij aan deze missie door technologieën te ontwikkelen voor innovatieve monitoring van water als onderdeel van urban farming en genoomgebaseerde detectiemethoden voor microbiologische fingerprinting (Next Generation Sequencing). Met NGS is snellere genetische analyse en diagnostiek mogelijk voor bijvoorbeeld het beter begrijpen van soortendiversiteit of analyse van microbiële populatie in (proces- en afval)water (veilige voeding, gezonde leefomgeving). Met biosensoren (bioassay, lab on a chip) kunnen snelle en effectieve analyses op laboratoriumschaal plaatsvinden in de voedingsindustrie en waterkwaliteitsbewaking.

Tot slot, draagt 'Smart Technology' aan missie D bij door slim gebruik te maken van dataficatie: door data uit de gehele keten te benutten kunnen tracking \& tracing toepassingen, e-health applicaties voor mens, bodem, plant en dier, herformuleringsvraagstukken, procesoptimalisaties, last mile vraagstukken worden aangepakt, en fraude met grondstoffen en voedselveiligheidsissues zo vroeg mogelijk in de keten worden opgespoord. Digital twins helpen bij snelle productontwikkelingen voor veilige productie enerzijds en een gezonder leefpatroon van de consument anderzijds.

Missie E. Duurzame en veilige Noordzee, oceanen en binnenwateren -- de LWV-missie Duurzame Noordzee, oceanen en binnenwateren is: "Voor de marine wateren is er in 2030 en voor rivieren, meren en estuaria in 2050 een balans tussen enerzijds ecologische draagkracht en waterbeheer (waterveiligheid, zoetwatervoorziening en waterkwaliteit) en anderzijds de opgaven voor hernieuwbare energie, voedsel, visserij en andere economische activiteiten."

Vanuit 'Smart Technology' wordt aan deze missie bijgedragen via de toepassingsgebieden nondestructieve kwaliteitsmetingen (vangstanalyse), water-land-energy-food nexus, monitoring biodiversiteit, smart water systems ('on site' en 'real time' meettechnologie voor waterkwaliteit en waterzekerheid, meet- en regeltechnologie en circulaire waterhuishouding). Scenariostudies en integrale afweging spelen een grote rol. In het subthema visserij is het van belang om de gevangen vis aan boord van het schip te detecteren, te classificeren (in gewenste vangst en bijvangst), en te processen. Hier speelt 'Smart Technology' een rol bij door camera-observaties toe te passen. Ook bij het 'on site' en 'real time' monitoren van waterkwaliteit en van acquatic farming systemen is Slimme Technologie nodig in de vorm van sensoren en voorspellende modellen. Sleutelwoorden die hierbij horen vanuit 'Smart Technology' zijn sensoren, big data, blockchain, AI, modellering, security, decision support systeem en human-computer interaction.

Deze toepassingsgebieden dragen bij aan de missie duurzame Noordzee, oceanen en binnenwateren door de expertkennis te koppelen aan big data verkregen uit allerlei sensoren, geanalyseerd met computer vision en AI-technieken. Hiermee kunnen beslissingsondersteunende slimme algoritmen worden gevoed die real time sturen om een balans te bereiken tussen ecologie en waterbenutting. Daarnaast is ook het optimaal benutten van data en slimme algoritmes ten behoeve van vangstanalyses en monitoren van plantaardige en dierlijke productie op zee, een aandachtspunt.

Missie F. Nederland is en blijft de best beschermde delta ter wereld, ook na 2100 -Technologische innovaties rond verbetering van waterkwaliteit en hergebruik van water dragen bij aan het verduurzamen van het waterbeheer in de delta. Voor energieopwekking en energieopslag in water wordt gebruik gemaakt van elektrochemische conversie en elektrochemische materialen (reverse elektrodialyse). Voor het toekomstige energiesysteem (met toenemende mate van elektrificatie) is nieuwe technologie nodig voor onder andere energieopslag, interconnectie, flexibilisering en omzetting naar chemicaliën op basis van kennis van materiaaltechnologie, reactor engineering, katalyse, warmteen transportleer, computational sciences en benodigde high- en lowtech engineering voor toepassing in de infrastructuur. Dit vraagt ondersteuning van de operators in het analyseren van de complexe real time data en de complexe vraagvoorspelling, waardoor een rol van AI en beslisondersteuning niet kan worden weggedacht. 
'Smart Technology' speelt een rol in deze missie via de toepassingsgebieden water-land-energy-food nexus en smart water systems. (Klimaat)modellen worden gebruikt om integrale afwegingen te maken voor reductie overstromingsrisico's, innovatieve vormen van energie uit water (bijv. MemPower) en waterbehandeling gecombineerd met real-time analyse van actuele noodzaak voor wel of geen interventie. Sleutelwoorden die hierbij horen zijn artificial intelligence, modellen, big data, simulaties, decision support, human-computer interaction, data integratie, lerende algoritmes, satellieten en drones.

Deze toepassingsgebieden dragen bij aan de missie beschermde delta Nederland door vroegtijdig te kunnen doorrekenen wat de te verwachten klimaateffecten zijn en wat de impact van verschillende mitigerende maatregelen zijn op het deltagebied Nederland.

\subsection{Conclusie maatschappelijke opgave}

De ambities geformuleerd in de LWV-missies en ook in de SDG's zijn groot. De potentiële toepassingen, reikwijdte en impact van 'smart technologies' in het Agro-Horti-Water-Food domein is breed. Dat zorgt ervoor dat er overal aanknopingspunten zitten om 'smart technology' ontwikkeling zo te richten dat ze bijdragen aan de ambitieuze missies.

De belangrijkste toepassingsgebieden die uit de maatschappelijke opgave komen zijn weergegeven in Tabel 1. Op elk van deze toepassingsgebieden vindt al onderzoek plaats, en op elk van deze toepassingsgebieden zijn grote stappen voorwaarts mogelijk. De analyse van waar de belangrijkste kennis- en innovatieopgaven zitten op deze toepassingsgebieden voor het komende decennium wordt gemaakt in hoofdstuk 4.2.

Tabel 1: overzicht van toepassingsgebieden waar 'smart technologies' een belangrijke rol kunnen spelen, gekoppeld aan de maatschappelijke opgave vanuit de missies.

\begin{tabular}{|c|c|c|c|c|c|c|}
\hline TOEPASSINGSGEBIEDEN & 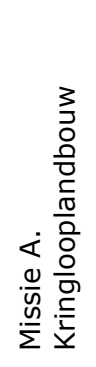 & 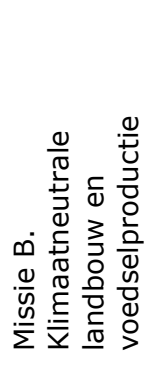 & 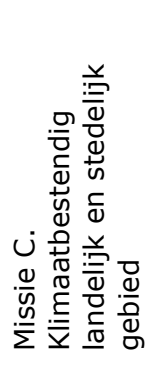 & 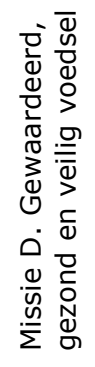 & 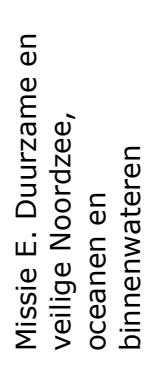 & 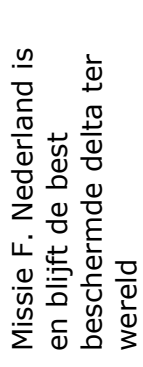 \\
\hline Precision farming & $x$ & $x$ & $x$ & $x$ & & \\
\hline Food waste prevention \& reduction & & $x$ & & $x$ & & \\
\hline $\begin{array}{l}\text { Water-Land-Energy-Food } \\
\text { nexus/Smart water systems }\end{array}$ & $x$ & & $x$ & $x$ & & $x$ \\
\hline Monitoring Biodiversiteit & $x$ & & & $x$ & $x$ & \\
\hline Personalised nutrition & & & & $x$ & & \\
\hline Last mile /e-commerce & & & $x$ & $x$ & & \\
\hline Trusted food supply chains & & & & $x$ & & \\
\hline Autonomous handling \& packaging & & $x$ & & $x$ & & \\
\hline Adaptive food processing & & $x$ & & $x$ & & \\
\hline Fenotypering & $x$ & & & & & \\
\hline Adaptive horticulture & $x$ & $x$ & $x$ & & & \\
\hline
\end{tabular}




\section{Beschrijving lopend onderzoek}

De beschrijving van het lopend onderzoek wordt via een aantal verschillende kanten bekeken. Doordat deze programmeringsstudie zich richt op 'Smart Technology in Agro-Horti-Water-Food' in het landbouwwater- en voedingdomein, brengen we als eerste het wereldwijde wetenschappelijk landschap in kaart door de top 5 van beste technologische universiteiten en de top 5 van beste agrofood instituten te bespreken. Van de technologische universiteiten onderzoeken we hoe zij de cross-over maken naar het agrofood domein in hun strategische agenda. Van de agrifood instituten bespreken we hoe 'Smart Technology in Agro-Horti-Water-Food' laten terugkomen in hun agenda.

Daarna richten we ons op het Nederlandse landschap. We brengen in kaart wat de 4 TU's doen op het gebied van 'Smart Technology' in het landbouw-, water- \& voedingdomein. In dit hoofdstuk bespreken we ook relevante faculteiten van algemene universiteiten. We sluiten de sectie af met relevante onderzoeksagenda's van de hogescholen en van (virtuele) samenwerkingsverbanden.

Het derde deel van dit hoofdstuk richt zich op de KIA's en call teksten van de topsectoren, op de Nederlandse Wetenschapsagenda en relevante call teksten uit het H2020-programma van de EU. In deze sectie belichten we een aantal lopende (en recent afgeronde) onderzoeken, waarbij het Nederlandse bedrijfsleven een rol speelt.

\subsection{Wereldwijde top 5 instituten op technologisch vlak}

Volgens topuniversities.com² zijn de top 5 technische centra in de wereld (1) Massachusetts Institute of Technology, USA (MIT), (2) Stanford University, USA, (3) University of Cambridge, UK, (4) Nanyang Technological University, Singapore, (5) ETH Zürich, Switzerland (zie Figuur 4).

MIT -- Voor deze studie zijn twee onderdelen van MIT relevant. Het eerste is de faculteit Electrical Engineering \& Computer Science (EESC). Aan deze faculteit wordt gewerkt aan robots, sensoren, computer vision, machine learning, artificial intelligence. Het tweede onderdeel is het Institute for Data, Systems and Society (IDSS). Dit instituut past slimme technologie (machine learning, sensoren, dataacquisitie) toe voor complexe maatschappelijke vraagstukken. Voorbeelden van toepassingsgebieden zijn landbouwkundig onderzoek in het algemeen en cyber agriculture specifiek. Tot slot heeft MIT het MIT Media Lab Open Agriculture Initiative (OpenAg) ${ }^{3}$ opgestart, waarin men zich richt op het versnellen van de wereldwijde digitale landbouw innovaties.

Stanford -- Het AI-lab (artificial intelligence laboratorium) van Stanford University is interessant voor deze programmeringsstudie. Dit SAIL lab ${ }^{4}$ richt zich op onderzoek en onderwijs, op theorie en praktijk. Sleutelwoorden zijn machine learning, deep learning, natural language processing, computer vision, robotics, genomics, autonome voertuigen. Ook in de Stanford Graduate School of Business wordt aandacht besteed aan de impact van nieuwe technologie op de agribusiness value chain ${ }^{5}$.

Cambridge -- ook bij Cambridge vinden we vergelijkbare sleutelwoorden terug in het 'Smart Technology' domein: artificial intelligence, mobile computing, computer vision, human-computer interaction, natural language processing, semantiek, geautomatiseerd redeneren, security, en sensor systemen. Cambridge investeert in de Agri-tech innovation hub, die fungeert als een demonstratiecentrum voor nieuw onderzoek, nieuwe technologie en innovatie voor boeren, producenten en verwerkende industrie ${ }^{6}$. Een vergelijkbare functie vervult de Cambridge Biomedical Campus op het domein van biotechnologie en gezondheidszorg ${ }^{7}$.

\footnotetext{
${ }^{2}$ https://www.topuniversities.com/university-rankings/university-subject-rankings/2017/engineering-technology, geraadpleegd op 17 april 2019.

${ }^{3}$ https://www.media.mit.edu/groups/open-agriculture-openag/overview/, geraadpleegd op 17 april 2019.

${ }^{4}$ http://ai.stanford.edu/

${ }^{5}$ https://www.gsb.stanford.edu/sites/gsb/files/publication-pdf/white-paper-vci-technology-agribusiness-opportunities-drivevalue.pdf

${ }^{6}$ https://www.meet-cambridge.com/sector/agriculture

${ }^{7}$ https://www.meet-cambridge.com/sector/bioscience-and-healthcare
} 


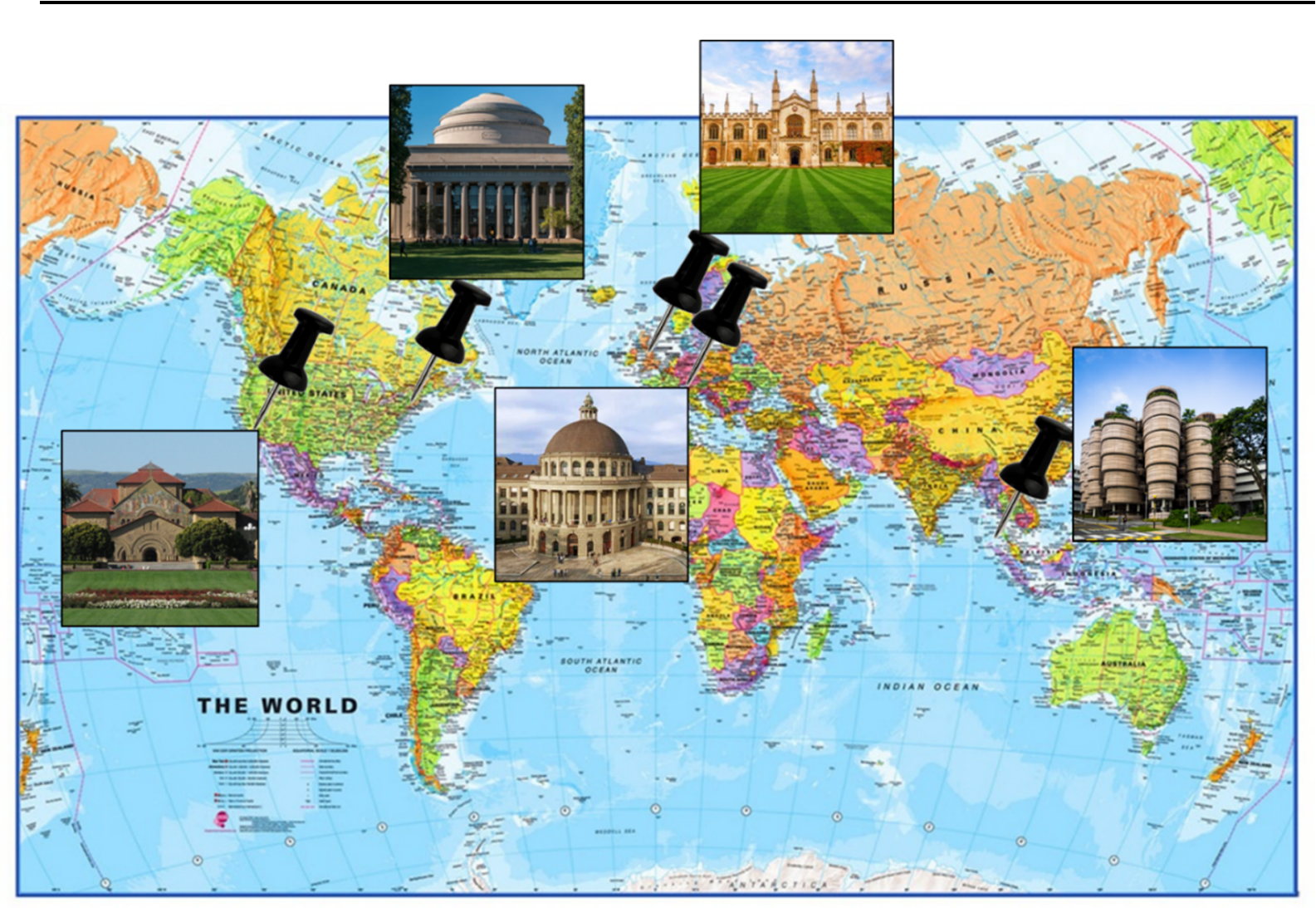

Figuur 4: De vijf technologische top universiteiten in de wereld: (1) MIT, (2) Stanford, (3) Cambridge, (4) Nanyang University Singapore, (5) ETH Zurich.

Nanyang Technological University Singapore -- de Nanyang technologische universiteit van Singapore heeft Food Technology \& Science als een van de speerpunten benoemd. Het terugdringen van voedselverspilling en het versterken van food security voor de wereldbevolking worden vanuit de universiteit benaderd met een interdisciplinaire aanpak, zowel in het primaire proces als in de postharvest keten. Sleutelwoorden hierbij zijn kunstmatige intelligentie, blockchains, sensoren en real-time beslissingsondersteuning ${ }^{8}$. Nanyang Technological University heeft in 2013 een strategische samenwerkingsband ${ }^{9}$ met Wageningen UR gecreëerd om deze multidisciplinaire aanpak te borgen.

ETH Zürich -- ETH richt zich met name op pharma, data, duurzaamheid en maaktechnologie. ETH heeft veel kennis over machine learning, computer vision, data science. Deze technieken worden ingezet om problemen op het gebied van food security, energielevering en klimaatverandering aan te pakken. ETH biedt een opleiding op het gebied van landbouwwetenschap aan, waarbij een deel van de studie voor informatica-gerelateerde vakken wordt gebruikt.

\subsection{Wereldwijde top 5 instituten voor agriculture \& forestry}

Volgens topuniversities.com ${ }^{10}$ zijn de top 5 agricultural \& forestry centra in de wereld (1) Wageningen UR, Nederland, (2) UC Davis (University of California), USA, (3) Cornell University, USA, (4) Berkeley University of California, USA, (5) AgroParisTech, Frankrijk (zie Figuur 5).

Wageningen University \& Research -- WUR beschouwt technologie als de drijvende kracht achter verbetering en vooruitgang in de maatschappij ${ }^{11}$. Technologie zit in agribusiness, in de processing

\footnotetext{
${ }^{8}$ https://www.ntu.edu.sg/fst/Pages/Research-and-Innovation.aspx

${ }^{9}$ https://www.wur.nl/en/show/Wageningen-UR-starts-collaboration-in-Singapore.htm

${ }^{10}$ https://www.topuniversities.com/university-rankings/university-subject-rankings/2016/agriculture-forestry, geraadpleegd op 17 april 2019.

${ }^{11}$ https://www.wur.nl/en/Education-Programmes/master/Technology.htm
} 


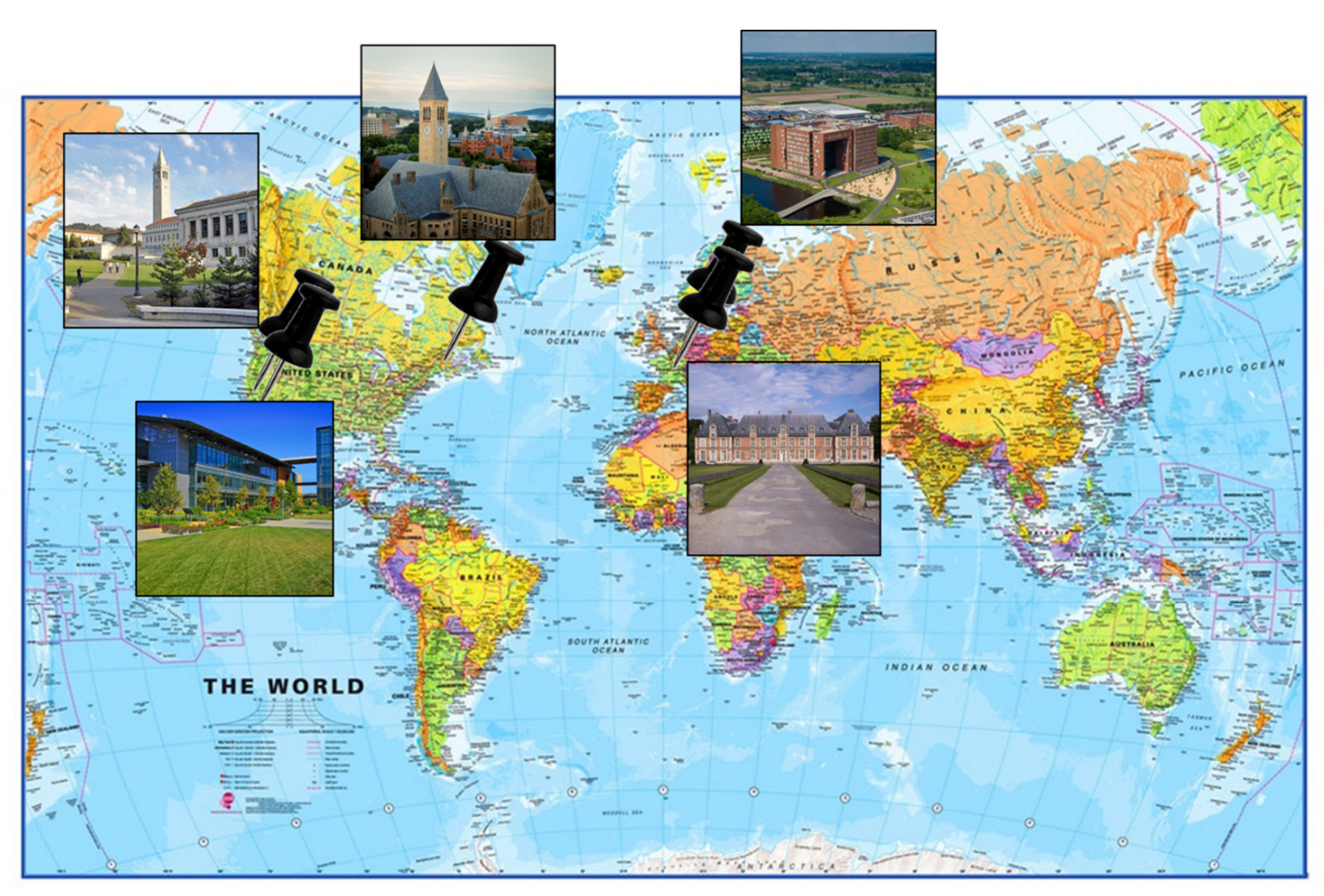

Figuur 5: De top 5 agricultural \& forestry centra in de wereld (1) Wageningen UR, (2) UC Davis, (3) Cornell University, (4) Berkeley University of California, (5) AgroParisTech.

industrie, in de supply chain. In 2017 heeft WUR het agile team Agro Food Robotics ${ }^{12}$ opgezet om op het gebied van robots, drones, sensoren, computer vision, machine learning en artificial intelligence oplossingen uit te vinden en toe te passen in het agrifood domein van primaire sector tot consument. Ook breder op het gebied van data science, statistiek, precisielandbouw, is expertise gevormd zowel op toegepast onderzoek als op onderwijsvlak ${ }^{13}$.

Binnen Wageningen UR is daarnaast een agile team gevormd op het gebied van diagnostiek: Diagnostiek@WUR. In dit team wordt de aanwezige kennis op het gebied van detectie en identificatie met elkaar gedeeld en versterkt. Detectie vindt plaats van verschillende stoffen (allergenen, hormonen, antibiotica, pesticiden, toxines, receptoren, nucleïnezuren, antilichamen en eiwitten) en organismen (humaan-, dierlijke- en plantpathogenen), die worden gemeten in dieren, planten, voedsel en landbouwkundige producten of substraten (grond, lucht, water etc.). Hiervoor worden verschillende technologieën ingezet, waaronder spectroscopie-gebaseerde diagnostiekmethoden.

UC Davis - Het College of Agricultural and Environmental Sciences richt zich op het oplossen van problemen in landbouw, milieu en human sciences om zo bij te dragen aan een betere wereld, gezondere levens en een hoge kwaliteit van leven voor iedereen ${ }^{14}$. Samen met het Environmental and Agricultural BioInformatics Computer Lab, wordt gewerkt aan een geavanceerde toepassing van informatietechnologie in het onderzoek ${ }^{15}$.

Cornell University - Cornell Tech bouwt aan een multidisciplinaire omgeving waar de wetenschap en de praktijk elkaar kunnen treffen op het gebied van creativiteit, onderzoek en het realiseren van digitale producten en diensten om maatschappelijke en commerciële behoeften te vervullen ${ }^{16}$. In het College of

\footnotetext{
12 http://www.wur.eu/agrofoodrobotics

${ }^{13}$ http://www.wur.eu

14 https://caes.ucdavis.edu/about

15 https://caes.ucdavis.edu/tags/informatics

${ }^{16}$ https://tech.cornell.edu/
} 
Agriculture and Life Sciences ${ }^{17}$ wordt aandacht geschonken aan computational biology, waar genomics, computer science, digital twins en modelleren bij elkaar komen qua expertise.

Berkeley University of California -- in het Berkeley Food Institute ${ }^{18}$ wordt gewerkt aan de toegankelijkheid van gezond en betaalbaar voedsel dat op een duurzame manier geproduceerd is. $\mathrm{Er}$ lijken geen speciale activiteiten te zijn op het gebied van 'Smart Technology in Agro-Horti-Water-Food'.

AgroParisTech -- AgroParisTech richt zich op het voeden van een groeiende wereldpopulatie via duurzame productie, behoud van natuurlijke grondstoffen, het ondersteunen van innovaties en het integreren van de bioeconomie. Hierbij wordt samenwerking gezocht op de gebieden agronomie, bosbouw, life sciences, food technology, biotechnologie, klimaat, gezondheid, natuurbehoud en gebiedsontwikkeling ${ }^{19}$. Een van de opleidingen binnen AgroParisTech richt zich op informatica, met als sleutelwoorden big data, decision support en business intelligence.

In Europa zijn naast Wageningen Research nog andere toonaangevende onderzoeksinstituten op het gebied van agro-food. INRA (Frankrijk), RISE Agrifood and Bioscience (Zweden) en FAO (UN, gebaseerd in Italië) mogen in het overzicht niet ontbreken.

INRA (Institut National de la Recherche Agronomique) -- INRA heeft zich tot doel gesteld landbouwsystemen te ontwikkelen die bijdragen aan een goede nutritionele food intake van alle mensen en die bijdragen aan de bioeconomie, die efficiënt en competitief zijn, die duurzaam zijn in de zin dat ze de natuur respecteren en natuurlijke bronnen op een verantwoordelijke manier benutten ${ }^{20}$. INRA bevat 13 departementen, waaronder het departement toegepaste wiskunde en informatica, waar het onderzoek zich toespitst op het vergaren van kennis uit data, het integraal modelleren van complexe systemen en het gebruik van modellen in optimalisatie en ontwerp. Voorbeelden van 'Smart Technology in Agri-Horti-Water-Food' onderzoek waarin INRA participeert zijn Digiporc (het ontwikkelen van digitale tools om dierenwelzijn in de varkenssector te verhogen), ATOL/EOL (standaardisatie in fenotypering van vee), AgroPhen (robot + data platform voor het scannen van gewassen).

RISE Agrifood and Bioscience (formerly known as SIK) -- Agrifood and Bioscience doet onderzoek op de gebieden productontwikkeling, process engineering, food \& environment en food safety. Hierbij wordt veel gebruik gemaakt van statistiek, simulaties en data analyse.

FAO (Food and Agricultural Organisation of the United Nations) -- FAO richt zich op het toepassen van haar kennis en expertise op vijf aandachtsgebieden om zo bij te dragen aan de SDG's. Deze vijf zijn (i) help honger, voedselonzekerheid en ondervoeding de wereld uit, (ii) maak landbouw, visserij en bosbouw duurzamer en productiever, (iii) maak armoede op het platteland minder, (iv) maak inclusieve en efficiënte landbouw en voedselsystemen mogelijk en ( $v$ ) maak levensonderhoud weerbaarder voor dreigingen en crises. Een van de activiteiten van FAO die op de cross-over tussen Smart Technology en het Agro-Horti-Water-Food domein is de ontwikkeling van Agrovoc, een standaard voor het annoteren van data in het domein. FAO draagt ook bij aan het geven van trainingen op het gebied van Smart Technology.

Samenvattend kunnen we stellen dat de meeste van de besproken 10 universiteiten en 3 onderzoeksinstituten de meerwaarde zien van de cross-over tussen het landbouw, voeding en water domein enerzijds en de technologische ontwikkelingen anderzijds. Wat opvalt is dat er een breed scala aan cross-over toepassingen wordt genoemd door de verschillende instituten. Daar waar de cross-over plaats vindt, wordt 'Smart Technology' (zoals gedefinieerd in Hoofdstuk 1 van deze studie) ingezet als sleutel tot de gewenste innovaties.

\footnotetext{
${ }^{17}$ https://cals.cornell.edu/

${ }^{18} \mathrm{https}: / /$ food.berkeley.edu/

${ }^{19} \mathrm{http}: / /$ www2.agroparistech.fr/Presentation-of-AgroParisTech.html

${ }^{20} \mathrm{http}: / /$ institut.inra.fr/en/Research-and-results/Strategies
} 


\subsection{Het Nederlandse onderzoekslandschap}

\subsubsection{Smart Technology in Agro-Horti-Water-Food aan de Nederlandse universiteiten}

Omdat deze programmeringsstudie zich richt op 'Smart Technology in Agro-Horti-Water-Food' toegepast in het domein van landbouw, voeding en water, richten we ons in eerste instantie in Nederland ook op zowel de technologische als de agriculture \& forestry universiteiten en instituten. Dit zijn de 4TU-instituten: TU Delft, TU Eindhoven, TU Twente en Wageningen UR.

Wageningen UR is hierboven beschreven (zie Wereldwijde Top 5 Agricultural Institutes). Als toevoeging is het interessant om de samenwerking tussen Wageningen UR, Radboud UMC, Radboud Universiteit en Imec Nederland te noemen, resulterend in het innovatiecentrum OnePlanet ${ }^{21}$. Dit innovatiecentrum richt zich op het ontwikkelen van duurzame technologie voor voeding, gezondheid en landbouw. Volgens de initiatiefnemers van OnePlanet zijn technologische

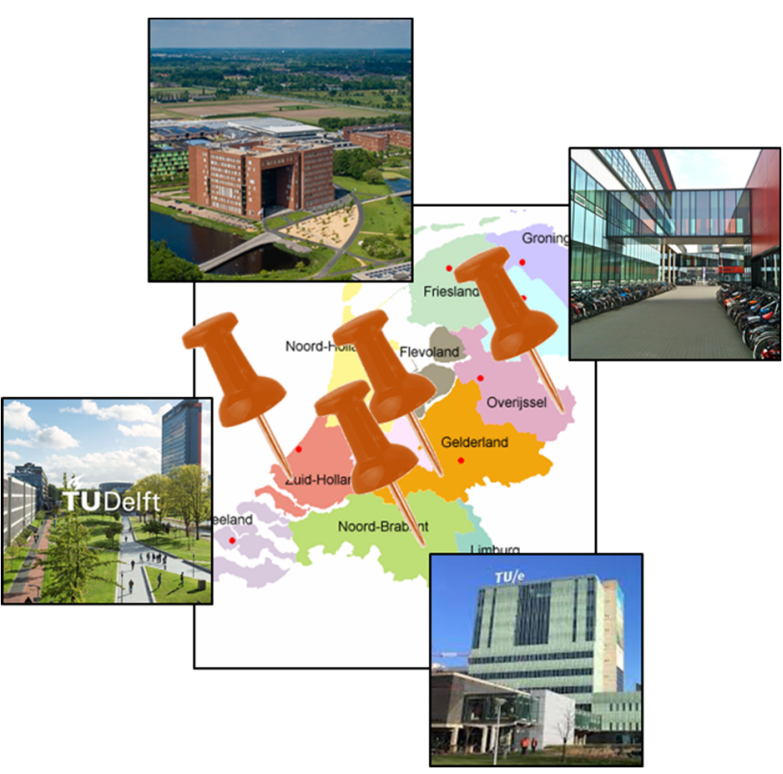

Figuur 6: De 4TU's: TU Delft, TU Eindhoven, TU Twente en Wagenigen UR. innovaties hard nodig voor maatschappelijke uitdagingen zoals klimaatverandering en bevolkingsgroei. Binnen het onderzoekscentrum zal onder andere worden gewerkt aan nieuwe technologieën voor de vroegtijdige signalering van ziektes bij mensen. Daarnaast zal de manier waarop wij voedsel verbouwen en consumeren worden geïnnoveerd. Met nieuwe landbouwtechnologie, zoals sensoren die voedingsstoffen in de grond en het water meten, of met slimme technologie voor de verticale landbouw, is het doel om met minder grondstoffen meer voeding lokaal te produceren. Vanuit de twee locaties Wageningen en Nijmegen gaan interdisciplinaire teams met onder andere voedseltechnologen, datawetenschappers, medici en biochemische onderzoekers samenwerken.

TU Delft - De Technische Universiteit Delft heeft meerdere faculteiten waarbinnen technologie wordt ontwikkeld met een mogelijke toepassing in de agrifood sector, zowel de primaire sector als de uiteindelijke consument. Denk aan sensortechnologie, plant computational biology, verslogistiekketens, nieuwe robottechnologie om tomaten te plukken, voedsel te verwerken of drones in zwermen te kunnen laten vliegen en onderling te laten communiceren. Een ander voorbeeld is machine learning toegepast op klimaat- en energiemodellen uit de kas i.c.m. met optimale opbrengst en uiteindelijk zelfs de fluctuerende marktvraag. Daarnaast is er ook in de open teelt een mogelijk toepassingsdomein voor hydrology en atmosferische fysica. Voor een duidelijke propositie als TU Delft in dit domein wordt op dit moment gewerkt aan een verankering van verschillende expertises in een Engineering in Agrifood programma. Hierin wordt actief gezocht naar samenwerking met Leiden-Delft-Erasmus en 4TU.

TU Eindhoven -- Maatschappelijke uitdagingen zijn de drijvende kracht voor het onderzoek dat aan de TU Eindhoven wordt uitgevoerd. Focus ligt daarbij in de strategische gebieden Gezondheid, Energie en Slimme Mobiliteit. Samenwerking tussen TU, industrie en overheid is georganiseerd in een aantal onderzoekscentra en instituten. Het High Tech Systems Center richt zich op de high tech en mechatronica van de toekomst, intelligent agents en meet- en regeltechniek. Het onderzoekscentrum Humans and Technology kijkt naar de relatie tussen mens en techniek op allerlei domeinen, waaronder energie en gezondheid. Het Data Science Center richt zich op technieken om kennis en inzichten uit data te halen, met aandacht voor menselijk gedrag, ethiek en business modellen. Smart Cities richt zich op het veiliger maken van steden, zowel op duurzaamheid, huisvesting, als ook op gezondheid en

\footnotetext{
${ }^{21}$ https://vimeo.com/320187090
} 
veiligheid. In het Engineering Health centrum wordt gekeken naar de interactie tussen biosensoren, data science, robotica en medicatie om zo te werken aan een gezondere leefstijl. Het Energy Center tot slot bekijkt het energievraagstuk vanuit technologisch perspectief. TU Eindhoven is een van de spelers in het interdisciplinaire en data-intensieve veld van AgriFoodTech (cross-overs tussen Agri-Food en Data, Robotica, Sensoren, Logistiek). Samen met Wageningen UR, HAS Den Bosch, Universiteit Utrecht en het Future Food programma wordt dit initiatief opgezet. Op 3D Food Printing hebben Wageningen Research en TU Eindhoven een samenwerkingsverband.

TU Twente -- Het ontwikkelen van oplossingen met maatschappelijke impact is de drijfveer voor de Universiteit Twente. Daarom focust de Universteit Twente zich de komende jaren op vijf wetenschappelijke thema's. 'Improving healthcare by personalized technologies' richt zich op gepersonaliseerde technologie die effectievere behandelingen kan bieden aan patiënten door middel van slimme toepassing van bijv. computer vision, robotica en apps. 'Creating intelligent manufacturing systems' werkt aan vernieuwingen in de maakindustrie. Hiervoor wordt bijv. VR/AR en goed datamanagement ingezet. 'Engineering our digital society' draait om de digitalisering van onze maatschappij. Big data, robots, human-computer interaction zijn relevante termen voor dit domein. 'Engineering for a resilient world' tot slot gaat om de rol die technologie kan spelen bij het verwezenlijken van de Sustainable Development Goals.

Behalve aan de 4TU's wordt ook bij een aantal algemene universiteiten gewerkt aan elementen uit de cross-over tussen Agro-Horti-Water-Food en Smart Technology.

Universiteit van Amsterdam -- aan de Science faculteit van de UvA wordt veel aandacht besteed aan de valorisatiethema's "Smart" en "Green". Binnen het thema "Smart" bevindt zich het innovatiecentrum voor kunstmatige intelligentie (ICAI), waarbinnen kwantumcomputing, machine learning en artificial intelligence verbonden zijn. Het ICAI bevindt zich in een nieuw gebouw op het Amsterdam Science Park, waar nieuwe kennis op het gebied van artificial intelligence, deep learning, language processing en robotica wordt ontwikkeld en wordt getoetst op socio-economisch niveau. Het thema "Green" omvat crop improvement, biodiversiteit, klimaatverandering, waterkwaliteit, circulaire economie, smart materials en duurzame chemie als onderzoeksthema's. Er worden technologische tools ontwikkeld om moleculen te detecteren en analyseren, om environmental genome sequencing uit te voeren en om beeldverwerking op cellulair niveau te doen met automatische beeldherkenning. Ook worden nieuwe technologieën ontwikkeld voor het vastleggen van $\mathrm{CO} 2$ en het produceren van biomaterialen.

Vrije Universiteit Amsterdam -- $W 4 R A^{22}$ (Web for Regreening in Africa) is een interdisciplinair netwerk binnen de Vrije Universiteit Amsterdam (VUA) dat zich sinds 2009 bezighoudt met FarmerManaged Regreening en andere activiteiten door middel van ontwerp en ontwikkeling van innovatieve ICT oplossingen voor kennisuitwisseling. Het ICT for Development (ICT4D) onderzoek van W4RA gebeurt in samenwerking met lokale partijen in West-Afrika en Zuid-Oost Azie en focust zich op nieuwe methoden voor requirements engineering, innovatieve mobiele en spraakinterfaces, en toepassingen van web technologieën. W4RA is lid van GODAN en het interdisciplinaire VU Netwerk Instituut.

Radboud Universiteit Nijmegen - De Radboud universiteit draagt met onderzoek bij aan maatschappelijke thema's zoals diagnostiek en behandeling op maat, taal en communicatie en water \& wetlands. Twee onderzoeksinstituten werken aan deelonderwerpen van 'Smart Technology'. Het institute for Computing and Information Sciences (iCIS) richt zich op het verbeteren van de fundamenten van software development. Artificial intelligence, machine learning, bioinformatica en data science zijn relevante steekwoorden. Het Donders Instituut voor Brain, Cognition \& Behaviour houdt zich bezig met het begrijpen van het menselijk brein, onder andere om van daaruit kunstmatige intelligentie te kunnen creëren. In de cross-over met het Agro-Horti-Water-Food-domein wordt niet specifiek onderzoek gedaan.

Tilburg University -- Tilburg University wil met haar onderzoek bijdragen aan een beter begrip van complexe maatschappelijke vraagstukken. Dat gebeurt door te kijken naar onderliggende structuren,

\footnotetext{
22 https://w4ra.org
} 
verbanden en betekenissen. Een van de onderzoeksinstituten is het Data Science Center Tilburg, waar actief cross-overs worden gezocht tussen 'Smart Technology' en verschillende domeinen. Een van de initiatieven is Data Science for Zero Hunger Lab dat zich richt op het bieden van data science oplossingen in de strijd tegen honger.

Aan de universiteiten van Groningen, Leiden, Maastricht, Rotterdam en Utrecht vinden veelal ontwikkelingen plaats op het 'Smart Technology' domein, zonder een speciale focus in het 'Agro-HortiWater-Food' domein.

\subsubsection{Smart Technology in Agro-Horti-Water-Food aan de Nederlandse hogescholen}

De sector Agro \& Food is met ruim 12.000 studenten de kleinste hbo-sector. De sector kent een aanbod van 'groen onderwijs' in brede $z^{2}{ }^{23}$. Verspreid over Nederland verzorgen vier hogescholen het hoger agrarisch onderwijs: Aeres Hogeschool, HAS Hogeschool, Hogeschool Inholland en Van Hall Larenstein. Door het hoger agrarisch onderwijs wordt samen met de partners uit het onderwijs, bedrijfsleven en overheden praktijkgericht onderzoek uitgevoerd. Op verschillende plekken vindt dat onderzoek plaats op de cross-over tussen 'Smart Technology' en 'Agro-Horti-Water-Food', bijvoorbeeld via de lectoraten:

- $\quad$ Big data in de aardappelketen (Aeres Hogeschool)

- Data-driven smart society (Hogeschool Inholland)

- Data uit satellieten, sensoren en smart phones (HAS Den Bosch)

- Precisielandbouw (Aeres Hogeschool)

- Precisievoeding in de duurzame pluimveehouderij (Aeres Hogeschool)

- Robotica (Hogeschool Inholland)

- Voedsel voor de metropool (Hogeschool Inholland)

- $\quad$ Herd management \& smart dairy farming (Van Hall Larenstein)

\subsubsection{Smart Technology in Agro-Horti-Water-Food aan de Nederlandse onderzoeksinstituten}

Tot slot zijn er de onderzoeksinstituten Wageningen Research, TNO, Deltares, Wetsus, Marin en KWR die (deels) opereren in het Agro-Horti-Water-Food domein en daar op verschillende plekken een crossover maken met 'Smart Technology'.

Wageningen Research -- is hierboven al genoemd. Via Agro Food Robotics, Wageningen Data Competence Center, statistisch expertisecentrum Biometris, de onderzoeksvelden Food Informatics en Keten \& Informatiesystemen wordt volop gewerkt aan 'Smart Technology for Agro-Horti-Water-Food'.

TNO -- Voor het beter kunnen realiseren van de doelen in de agrifood sectoren, richt TNO zich met name op verdere digitalisering op basis van een systeemaanpak waarbij de schakels binnen de voedselproductieketen volledig gedigitaliseerd worden, nieuwe (data gedreven) business modellen worden geïntroduceerd en acceptatie van innovaties door de gebruikers in de agrifood aandacht krijgt. Digitalisering betekent het toepassen van sensortechnologie (of Internet of Things), Grootschalige IT architecturen voor real time transport van (sensor)data, Artificial Intelligence en machine learning voor analyse van de data en toepassing van blockchain, ontologieën en semantiek voor transparante, vertrouwde, gestandaardiseerde en eenduidig te interpreteren data.

Deltares -- Ambitie van Deltares op dit gebied is te zorgen voor toekomstbestendige voedselvoorziening in de wereld. Door klimaatverandering treden vaker situaties met droogte op. Deltares brengt de effecten hiervan op zoetwaterbeschikbaarheid in kaart. De kennisontwikkeling en het vinden van innovatieve oplossingen leidt tot optimaal (her)gebruik van water en linkt daarmee aan link met SDG 2

\footnotetext{
${ }^{23}$ https://www.vereniginghogescholen.nl/sectoren/agrofood
} 
(Geen honger), SDG 6 (voldoende en schoon water voor iedereen) en SDG 13 (Climate Action: voldoende water met juiste kwaliteit op het juiste moment). Hiervoor zoekt Deltares samenwerking met strategische partners voor kennisontwikkeling en toepassing door inzet van globale modellen, verbetering van de relatie tussen water en optimale gewasgroei, mogelijkheden voor hergebruik en voorspelling van beschikbaarheid van water en het vinden van innovatieve oplossingen.

Inzet van digitale hulpmiddelen in combinatie met hoge resolutiegegevens uit meerdere bronnen leidt tot interessante mogelijkheden die kunnen bijdragen aan het optimaliseren van de bedrijfsvoering van landbouwbedrijven, toeleveranciers en afnemers.

Wetsus -- Wetsus is het Europese center of excellence voor duurzame watertechnologie. Wetsus doet op 'Smart Technology'-vlak onderzoek naar sensoren en smart water grids. Nieuwe sensoren worden ontwikkeld om waterkwaliteit te monitoren, zowel van drinkwater, als van industrieel (afval)water als van oppervlaktewater. Een aanpalend vakgebied gaat over de signaalanalyse, human-computer interface en data interpretatie. Sensoren vormen een IoT netwerk, waarin het mogelijk wordt data te combineren op grote schaal. Smart water grids gaat over het beheer van het waternetwerk, waarbij het belangrijk is de kwaliteit van de waterleidingen te kunnen monitoren en voorspellen, zodat storingen en lekkages zoveel mogelijk voorkomen kunnen worden. Dit vraagt accurate modellen, sensordata en historische data om semiautomatisch beslissingen te kunnen maken.

Marin -- Toegepast onderzoeksinstituut MARIN biedt de maritieme sector kennis en onafhankelijk onderzoek op het gebied van schonere, veiligere en slimmere schepen en maritieme constructies en duurzaam gebruik van de zee. Smart technology speelt hier een rol bij: er worden (big) data analyses uitgevoerd, modellen ontwikkeld voor simulaties en scenario studies, en de complexe maritieme operaties worden gecombineerd met de capaciteiten van menselijke operators ondersteund door adviessystemen. De volgende stap in de evolutie van de scheepvaart is de ontwikkeling van autonome schepen. MARIN heeft een belangrijke rol bij het onderzoek en de operationele tests die nodig zijn om autonome schepen te ontwikkelen.

KWR -- De beschikbaarheid van voldoende, schoon water is een wereldwijd maatschappelijk vraagstuk geworden. KWR genereert kennis om de watersector in staat te stellen water-wise te opereren in de verstedelijkte samenleving. In een water-wise world werkt KWR aan een optimale inrichting en beheer van de watercyclus, met een circulaire economie als belangrijke drijfveer. Onderzoek vindt onder andere plaats op het thema enabling technologies. Enabling technologies focust op de laatste ontwikkelingen in technologie, materialen, informatica en genomics zodat we die kunnen vertalen naar en inzetten in het watermanagement, met aandacht voor belangrijke factoren als kosten, veiligheid, duurzaamheid, weten regelgeving en maatschappelijke acceptatie.

\subsubsection{Smart Technology in Agro-Horti-Water-Food in samenwerkingsverbanden}

Nederland kent vele samenwerkingsverbanden tussen onderzoeksinstellingen, bedrijfsleven en (lokale) overheden waarbij onderzoek op de cross-over tussen Smart Technology en Agro-Horti-Water-Food een element is. Hieronder volgt een selectie.

AgriFoodTech Platform -- Het AgriFoodTech Platform wil de maatschappelijke betrokkenheid en dialoog over toepassing van techniek in land- en tuinbouw en de hieraan gelieerde verwerkende industrie op gang brengen en verbreden. Hiermee wil zij bijdragen aan een leefbare, welvarende en duurzame wereld, waarbij Nederland als voorbeeldland centraal staat. Middels het ontwikkelen van sociale en technologische innovaties kan het platform bijdragen aan het verstevigen van de (economische) positie van Nederland. Het STT rapport 'Van autonome robots tot zilte aardappels' en de mede daarop gebaseerde technologie roadmap 'High Tech to Feed the World' zijn directe aanleidingen om via het platform ook de maatschappelijke en sociale aspecten van innovatie in de agrifood sector aandacht te geven. Door de intensieve koppeling te versterken tussen Agri \& Food, Tuinbouw \& Uitgangsmaterialen, Hightech \& ICT en design vindt acceleratie van innovatie plaats. Het platform gaat zich hard maken voor innovaties die veelbelovend zijn, maar die nog niet ver genoeg zijn om geïmplementeerd te worden in 
de markt. Het platform helpt om de innovatie op korte termijn gereed te krijgen, zodat deze zo snel mogelijk bij de boer, tuinder of levensmiddelenfabrikant gebruikt kan worden ${ }^{24}$.

I3B -- i3B is een netwerk van hightech bedrijven en kennisinstituten dat zich richt op gezamenlijk onderzoek en commercialisatie van innovatieve digitale oplossingen om mensen en dieren te monitoren. Het netwerk richt zich op vier domeinen: veiligheid, voeding, gezondheid en mobiliteit. Het netwerk is opgericht door het NIHC (National Initiative Brain and Cognition), Wageningen UR en Noldus IT. i3B ontwikkelt digitale tools om te meten, analyseren en feedback te geven in een breed scala aan omstandigheden zoals eten, kopen, rijden, human-system interactie, bewegen, stress, sociale interactie, psychische stoornissen, ergonomie van de werkplek, kwaliteit van slapen en precisie dierhouderij. ${ }^{25}$

NPPL (Nationale Proeftuin Precisielandbouw) -- Precisietechnieken blijken op het akkerbouwbedrijf minder praktijkrijp dan waarmee ze in de markt zijn gezet. Van plug and play is veelal geen sprake. Het project Nationale Proeftuin Precisielandbouw helpt boeren en tuinders verder met het toepassen van deze technieken. Wageningse experts helpen 16 deelnemers om op hun bedrijf concreet aan de slag te gaan met toepassingen van precisielandbouw. Het NPPL is een initiatief van Wageningen UR, Aeres Hogeschool, Proagrica en Ministerie van LNV. ${ }^{26}$

JADS (Jheronimus Academy of Data Science) -- Het JADS is een samenwerkingsverband tussen TU Eindhoven, Tilburg University, de gemeente Den Bosch en de provincie Nood-Brabant. Het JADS richt zich op onderwijs en onderzoek op het gebied van Data Science. Een van de toepassingsgebieden is Data \& Agrifood waarbij onderzoek wordt gedaan naar het verduurzamen en verhogen van de voedselproductie wereldwijd door een cross-over te maken tussen Agrifood, Data en Engineering. ${ }^{27}$

Holland Robotics -- Holland Robotics is een landelijke robotica-community die de nationale samenwerking tussen wetenschap, industrie en robotica-entiteiten naar een hoger plan brengt. Met High Tech NL als aanjager, hebben de vier technische universiteiten, de Vrije Universiteit Amsterdam en de Rijksuniversiteit Groningen zich verenigd, samen met de grote industriële partijen DEMCON, VDL Enabling Technologies Group, Philips, Lely en Vanderlande Industries. Holland Robotics is een landelijke roboticabeweging, die ervoor gaat zorgen dat de roboticakennis in Nederland maximaal wordt benut. Een nationaal samenwerkingsverband tussen industriële spelers en wetenschapsinstellingen uit de Nederlandse hightechsector. Deze krachtenbundeling heeft als belangrijkste doel de internationale concurrentiepositie te verstevigen. ${ }^{28}$

dutch digital delta -- Nederland behoort tot de absolute wereldtop van digitale economieën. Veel huishoudens hebben een pc, tablet én smartphone en ons mobiele netwerk is erg goed ontwikkeld. Bijna alle Nederlandse bedrijven werken online en onze internetservers zijn de veiligste ter wereld. ICT en internet zijn in toenemende mate motoren voor innovatieve producten en diensten en daarmee voor economische groei. Van de landbouw en de gezondheidszorg tot het onderwijs, logistiek en de wetenschap: geen sector kan nog zonder ICT. Elke (top)sector kent zijn eigen ICT-uitdagingen, maar er zijn ook veel dwarsverbanden. Een succesvolle toepassing van een ICT-oplossing in de ene sector, kan bijvoorbeeld ook toegepast worden in een andere sector. Het doel van dutch digital delta is om die dwarsverbanden om te zetten in kansen. Als deze beter benut worden, kunnen we de innovaties in de ICT ook in de toekomst optimaal verzilveren en daarmee de economische groei in Nederland bevorderen. ${ }^{29}$

NPEC (Nederlandse Plant Eco-fenotypering Centrum) -- NPEC is een samenwerkingsverband tussen Wageningen UR en Universiteit Utrecht. Deze nationale onderzoeksfaciliteit biedt een modulaire

\footnotetext{
${ }^{24}$ https://agrifoodtechplatform.nl/

${ }^{25}$ https://www.i3b.org/

${ }^{26}$ https://www.proeftuinprecisielandbouw. nl/

27 https://www.jads.nl/

${ }^{28}$ https://www.hollandrobotics.com/

${ }^{29}$ https://dutchdigitaldelta.nl/
} 
faciliteit waarbij onderzoekers van universiteiten, onderzoeksinstituten en bedrijfsleven high-throughput plant fenotyperingsonderzoek kunnen uitvoeren. Focus ligt op het begrijpen van de relatie tussen plant performance en biotische en abiotische factoren op allerlei schalen: van molecuul tot gewas, van nanometer tot kilometer. ${ }^{30}$

Behalve deze initiatieven zijn er in Nederland zes Greenports (Greenport West-Holland, Greenport Aalsmeer en omstreken, Greenport Venlo, Greenport Duin- en Bollenstreek, Greenport Boskoop en Greenport Noord-Holland Noord) ${ }^{31}$ die zich richten op versterking van het agrofoodcomplex en ontwikkeling van kennisintensieve agribusiness.

\subsection{Lopende projecten op het gebied Smart Technology in Agro-Horti-Water-Food}

Onderzoek kan geclassificeerd worden in verschillende TRL-levels (Techology Readiness Levels, zie Figuur 7). Voor deze programmeringsstudie is onderzoek op TRL-levels 2 tot en met 6 interessant: TRLlevel 1 is te fundamenteel voor de scope, vanaf TRL 7 is er sprake van implementatie in de praktijk en is er geen sprake meer van onderzoek, waardoor ook deze TRL-niveaus buiten de scope van deze programmeringsstudie vallen.

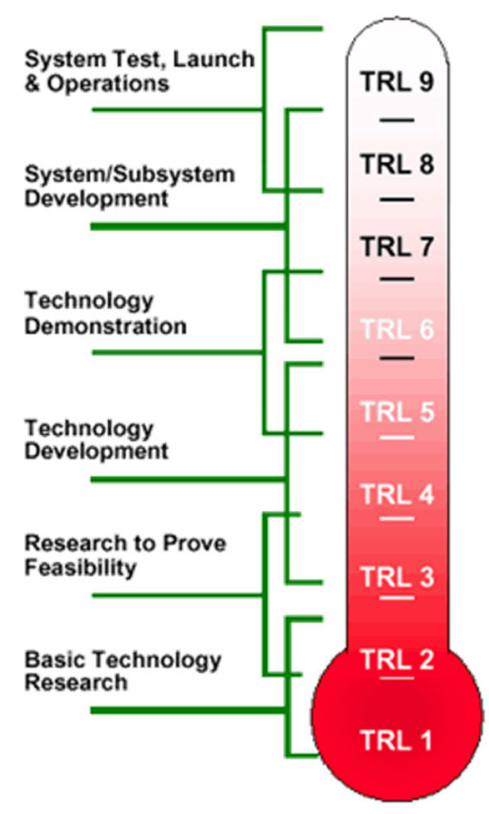

Figuur 7: Overzicht van de TRL-schaal gedefinieerd door NASA (bron: http://as.nasa.gov/aboutus/trl-introduction.htmI).

In Nederland wordt onderzoek op het gebied van Smart Technology in Agro-Horti-Water-Food gefinancierd vanuit verschillende publieke middelen. Onderzoek op een TRL-niveau 1 en 2 wordt typisch door NWO gefinancierd. Onderzoek gefinancierd door de topsectoren is typisch van TRL-niveau $3 \mathrm{t} / \mathrm{m}$ 6. EU-gefinancierd onderzoek kan op alle TRL-niveaus voorkomen. Voor deze studie focussen we op EUonderzoek op TRL-niveaus 2 en 3. Tot slot zijn er kennisbasis (KB)-programma's die zich op TRLniveaus $2 \mathrm{t} / \mathrm{m} 5$ bevinden.

\subsubsection{Lopende projecten gefinancierd door de topsectoren A\&F, T\&U en Water}

In dit hoofdstuk hebben we een analyse gemaakt van het PPS-onderzoek (TKI-gefinancierd) op het gebied van 'Smart Technology in Agro-Horti-Water-Food'. We hebben hiervoor een selectie gemaakt van het onderzoek op dit gebied dat in of na 2015 gestart is. Er komen 75 projecten uit de selectie naar boven, 31 gefinancierd vanuit de topsector Agri \& Food, 25 vanuit de topsector Tuinbouw \&

\footnotetext{
${ }^{30}$ https://www.npec.nl/en/npec.htm

${ }^{31}$ https://www.agriholland.nl/dossiers/greenports/
} 


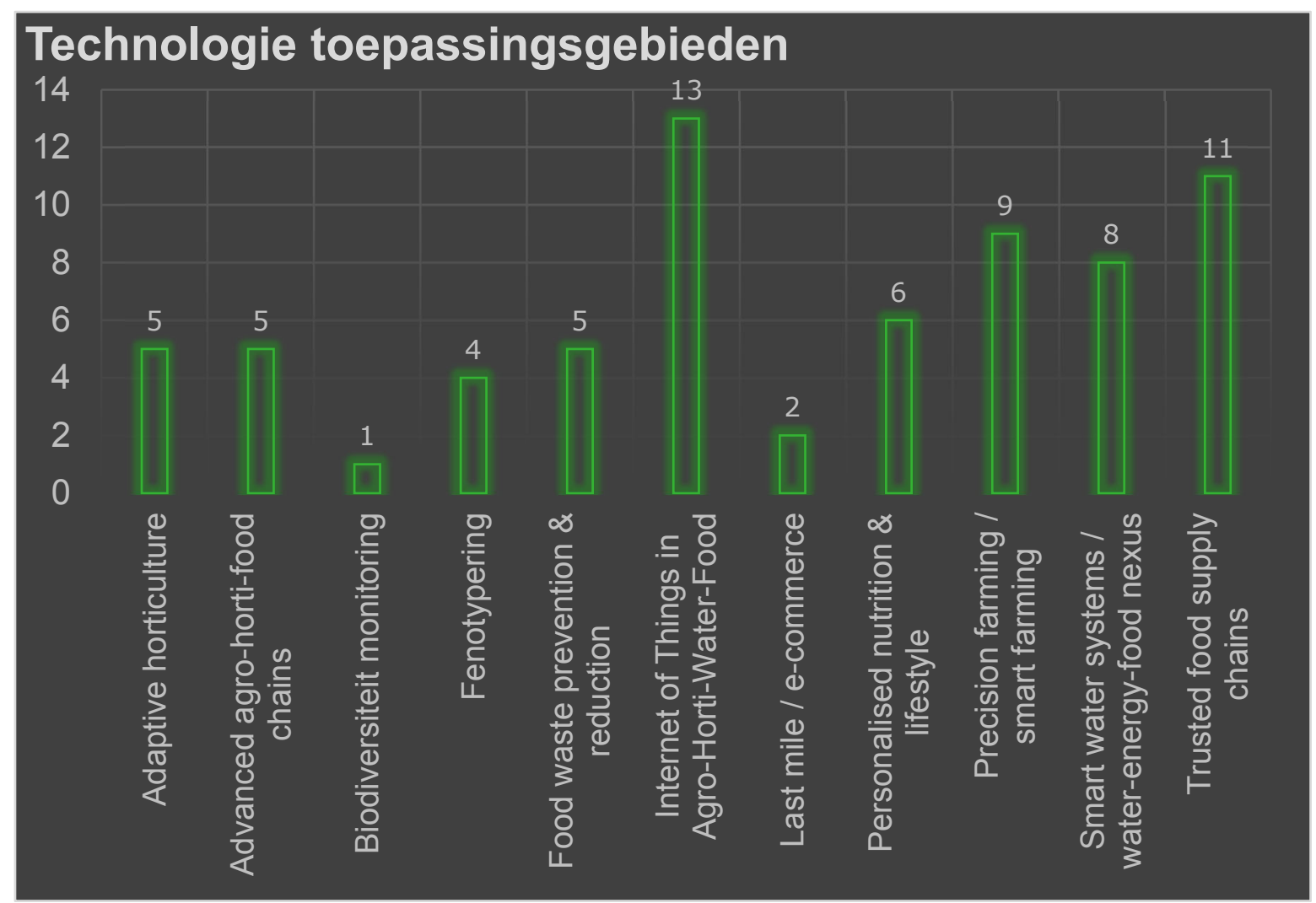

Figuur 8: Overzicht van analyse topsector-gefinancierde projecten t.a.v technologietoepassing.

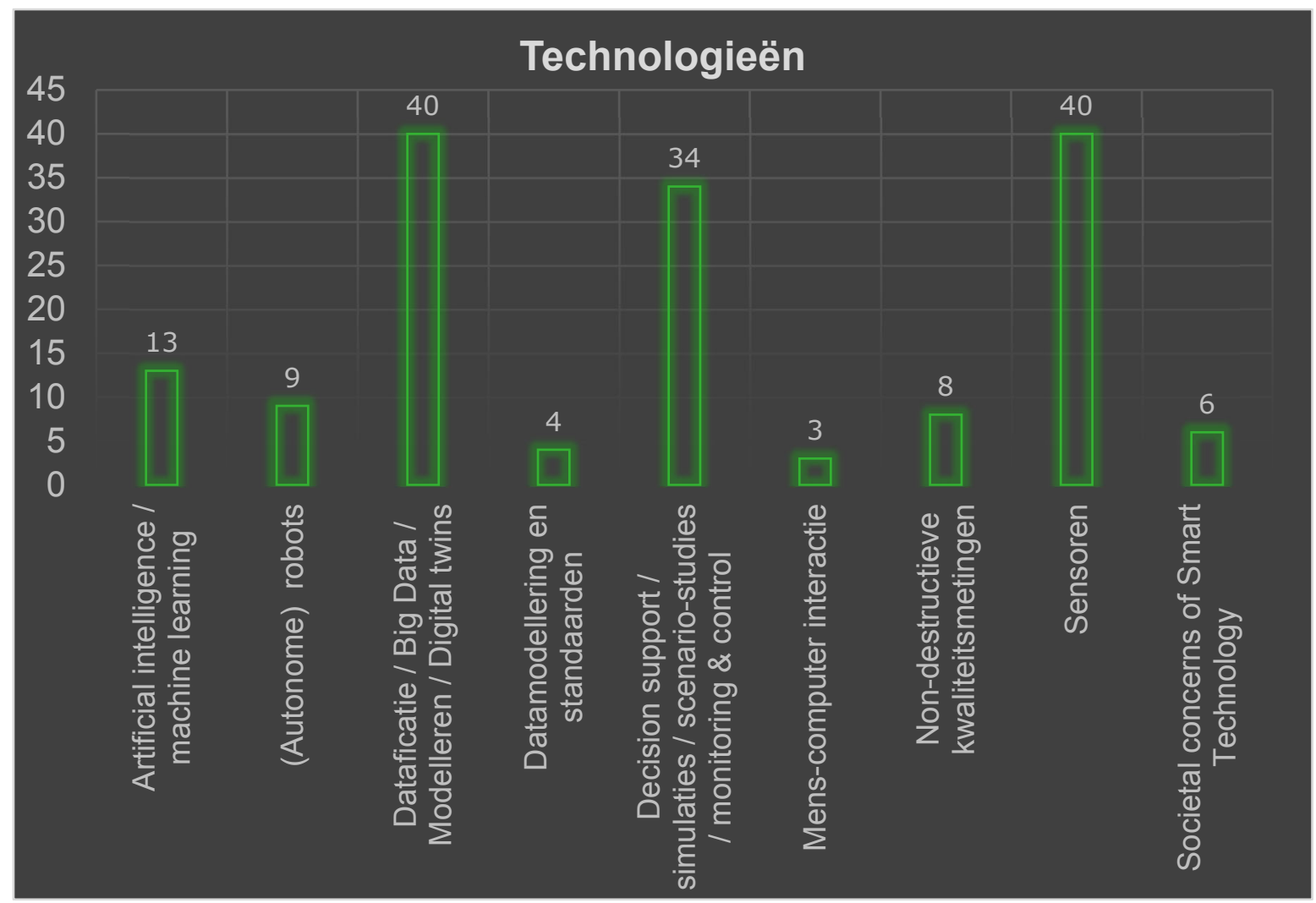

Figuur 9: Overzicht van analyse topsector-gefinancierde projecten t.a.v. gebruikte smart technologies. 
Uitgangsmaterialen en 21 gefinancierd vanuit de topsector Water. Deze projecten zijn geclassificeerd op hun bijdrage aan technologische toepassingsgebieden in het Agro-Horti-Water-Food domein en op hun connectie met onderwerpen uit het Smart Technologie-domein. Details van deze classificatie zijn te vinden in Bijlage $B$.

Uit de analyse blijkt dat het huidige PPS-onderzoek met name op de toepassingen van Internet of Things (13 van de 75 projecten), Trusted Food Supply Chains (11 van de 75 projecten) en Precision Farming / Smart Farming ( 9 van de 75 projecten) plaats vindt.

Qua technologieën wordt met name ingezet op Dataficatie / Big Data / Modelleren / Digital twins (40 van de 75 projecten), Sensoren (40 van de 75 projecten), Decision support / simulaties / scenariostudies / monitoring \& control (34 van de 75 projecten). Artificial intelligence en robots, samen goed voor 22 van de 75 projecten zijn duidelijk in opkomst.

Concluderend kun je stellen dat de projecten goed inspelen op de mogelijkheden die 'smart technologies' bieden om beter gebruik te maken van data in het hele proces: gebruik van sensoren om veel meer data te verkrijgen ('sense'), inzet van modellen en dataficatie om de data beter te interpreteren en beslissingen mee te ondersteunen ('think'), en gebruik van robots en artificial intelligence om autonoom handelingen te laten verrichten ('act'). Doelen die hierbij worden nagestreefd liggen op samenwerking tussen primaire sector en keten (trusted food supply chains) en op interconnectivity van processen die voorheen op zichzelf stonden (internet of agro-horti-water-food).

\subsubsection{Lopende projecten gefinancierd door de EU}

Ook voor de EU-projecten met TRL-niveaus 2 en 3 op het Smart Technology in Agro-Horti-Water-Food domein is een analyse gemaakt. Hierbij ging het over $51 \mathrm{EU}$-projecten die uit de selectie kwamen op de cross-over tussen Smart Technology en Agro-Horti-Water-Food. Ook deze projecten zijn zowel geclassificeerd op hun bijdrage aan technologische toepassingsgebieden in het Agro-Horti-Water-Food domein als op hun connectie met onderwerpen uit het Smart Technologie-domein. De gedetailleerde analyse is te vinden in Bijlage $\mathrm{C}$.

Uit de analyse blijkt dat het huidige EU-onderzoek op de cross-over tussen Smart Technology en het Agro-Horti-Water-Food domein met name op de toepassingen van Precision farming / smart farming (20 projecten) plaats vindt, Daarna volgt een groot aantal onderzoeksprojecten waarin Smart Technology in onderzocht en toegepast wordt. Wat opvalt in Figuur 10 is dat op het gebied van Food waste prevention \& reduction geen projecten zijn. Waarschijnlijk heeft dat ermee te maken dat de projecten niet nadrukkelijk gebruik maken van de mogelijkheden van Smart Technology.

Qua technologieën wordt met name ingezet op de onderwerpen Dataficatie / Big Data / Modelleren / Digital twins (32 van de 51 projecten) en Datamodellering en standaarden (34 van de 51 projecten). Op goede afstand volgen de projecten waarin Sensoren (16 van de 51 projecten) en Non-destructieve kwaliteitsmetingen (15 van de 51 projecten) een rol spelen, waarna alle andere onderwerpen volgen met een incidenteel project.

\subsubsection{Lopende projecten gefinancierd vanuit de kennisbasisprogramma's}

Tot slot zijn de kennisbasis (KB) deelprogramma's met een sterke connectie met Smart Technology in het Agro-Horti-Water-Food domein geanalyseerd. Hierbij gaat het om $10 \mathrm{~KB}$-deelprogramma's uit de kennisbasis Data Driven \& High Tech (6 stuks) en de kennisbasis Gezond \& Veilig (4 stuks).

Vanuit het kennisbasisprogramma Data Driven \& High Tech wordt geïnvesteerd in de volgende onderwerpen:

- KB DDHT 1 Data analytics for food chains and consumer-oriented research

- $\quad$ KB DDHT 2 AI in animal and arable systems

- KB DDHT 3 Data-driven phenotyping

- $\quad$ KB DDHT 4 Smart \& privacy conserving infrastructures

- $\quad$ KB DDHT 5 Autonomous Robots for agri-food processes 


\section{Technologie toepassingsgebieden}

\section{0}

15

10
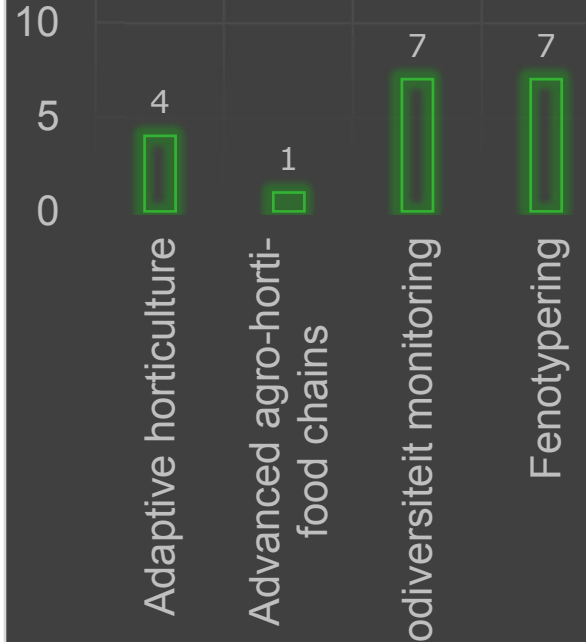

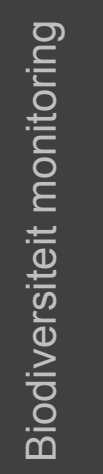

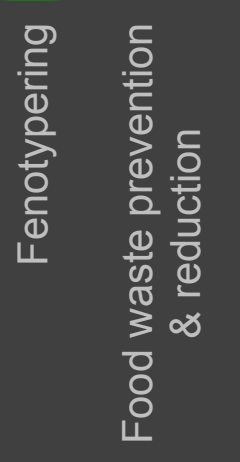

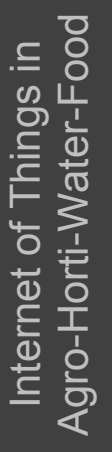

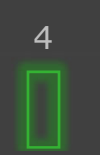

5

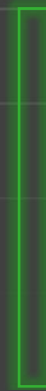

Figuur 10: Overzicht van analyse EU-gefinancierde projecten t.a.v. technologie-toepassing.

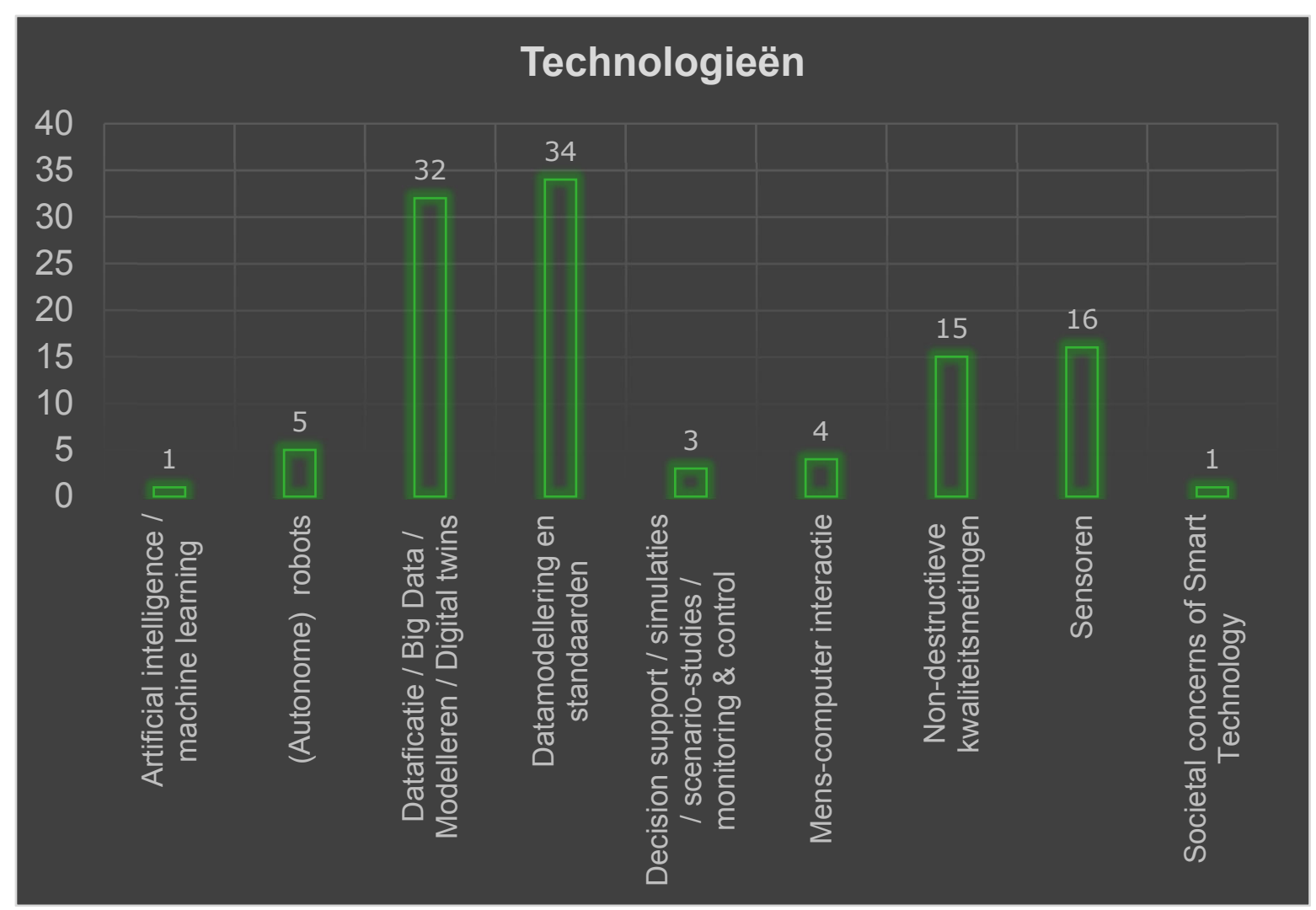

Figuur 11: Overzicht van analyse EU-gefinancierde projecten t.a.v. gebruikte smart technologies. 
Vanuit het kennisbasisprogramma Gezond \& Veilig zijn de volgende onderwerpen relevant voor deze programmeringsstudie:

- KB37-001-002 Biomarkers, diagnostics, measurements and effective consumer feedback

- KB37-001-004 Diagnostics @ WUR

- KB37-001-005 New technology for measuring, understanding and affecting consumer food choices

- $\quad$ KB37-001-006 Emerging health risks 


\section{Witte vlekken analyse}

'Smart technologies' is een van de game changers in de Agro-Horti-Water-Food sector. Er vindt al veel onderzoek plaats op de cross-over van de technologie met het toepassingsgebied. De belangrijkste reden daarvoor is dat de potentie van 'smart technologies' groot is, de voordelen van digitalisering onbetwist zijn, en de ontwikkelingen elkaar in hoog tempo blijven opvolgen. Wat een aantal jaar geleden state-of-the-art onderzoek was is nu standaard praktijk geworden. Denk bijvoorbeeld aan de belemmeringen die er waren op het gebied van infrastructuur om connectiviteit voor elkaar te krijgen. Tegenwoordig is er $4 G$, bijna $5 G$, en is vrijwel iedereen altijd online. Het probleem van een goede connectiviteits-infrastructuur is verdwenen uit het onderzoeksdomein, het is nu een kwestie van engineering en financiering om connectivity in alle hoeken en gaten van Nederland goed geregeld te krijgen. In het brede veld van informatisering is nog veel onderzoek nodig om de voordelen van die basisinfrastructuur ten volle uit te nutten.

Nieuwe ontwikkelingen, zowel technologisch als maatschappelijk, zijn aanleiding voor nieuwe vragen. Die vragen zijn niet alleen technisch, maar ook maatschappelijk, economisch en ethisch van aard. Als kunstmatige intelligentie steeds intelligenter wordt, is dat dan veilig voor de mensheid? Als regeringen autonome drones gebruiken in oorlogssituaties, heeft er dan nog iemand voldoende controle om in te grijpen? Als al onze data online staan, wie garandeert dan onze privacy? Als we voortdurend connected zijn, zijn we dan niet kwetsbaar voor cyberaanvallen? Als ik online data deel met partijen die ik vertrouw, kan ik dan nog data voor mijn eigen bedrijfsvoering afschermen? Als robots steeds autonomer worden, wat gebeurt er dan met de werkgelegenheid? Dit soort vragen vatten we samen onder de noemer "societal and economic concerns". Het is essentieel dat er aandacht is voor deze vragen: technologieontwikkeling zonder aandacht voor societal concerns en ethische vraagstukken is onverstandig. Omdat deze vragen de technologieën in zijn geheel betreffen, liggen ze deels buiten de scope van deze programmeringsstudie, aangezien de programmeringsstudie zich richt op onderzoek \& development specifiek in het agro-horti-water-food domein. Waar de "societal and economic concerns" het agro-hortiwater-food domein raken, worden ze derhalve wel behandeld. Dit is bijvoorbeeld het geval bij de impact van robotica op dierenwelzijn in de precisiehouderij, de inzet van robots als arbeidskracht en de consequenties daarvan op de arbeidsomstandigheden van de resterende menselijke arbeidskrachten, of de vragen rondom privacy bij het aanbieden van gepersonaliseerd voedseladvies.

Ontwikkelingen op het gebied van Smart Technology vindt plaats op alle technology readiness levels (TRL's). Op de hoogste TRL's liggen de vraagstukken op engineering, financiering en adaptatie, hier is slechts beperkt onderzoek nodig. Toegepast onderzoek vindt plaats op TRL-niveaus 2 t/m 5, fundamenteel onderzoek op levels $1 \mathrm{t} / \mathrm{m} 3$. Voor de witte vlekkenanalyse in deze programmeringsstudie beperken we ons tot de TRL-niveaus $2 \mathrm{t} / \mathrm{m}$ 5: niet te fundamenteel van aard, wel in het (toegepaste) onderzoeksdomein.

De witte vlekkenanalyse is als volgt opgebouwd. Allereerst beschouwen we verschillende onderwerpen die kenmerkend zijn voor het gebied van 'Smart Technology'. We beschouwen de kennis- en innovatieopgaven in elk van deze onderwerpen (paragraaf 0). Daarna belichten we de technologische toepassingen uit het lopend Agro-Horti-Water-Food onderzoek, zoals bijv. precisielandbouw, adaptive horticulture of food waste prevention \& reduction. Voor elk van deze technologische toepassingen geven we een blik voorwaarts en identificeren waar het onderwerp op deze toepassingen heen zou kunnen gaan (paragraaf 4.2). Door deze stap in de analyse hebben we de witte vlekken in het lopende onderzoek in kaart. Het is ook interessant om te identificeren of er witte vlekken zijn buiten het huidige onderzoek die relevant zijn voor de sector en waarin geïnvesteerd zou moeten worden. Om daar een beeld van te krijgen zijn vier technologische trendanalyses bekeken en geanalyseerd op hun potentie voor het AgroHorti-Water-Food domein (paragraaf 4.3). 


\subsection{Kennis- en innovatieopgaven smart technology onderwerpen}

Deze witte vlekken analyse beschouwt de 8 onderwerpen waarop het lopend onderzoek beoordeeld is (hoofdstuk 3). Van elk onderwerp wordt de huidige stand van zaken, de belofte voor de nabije en middellange toekomst en de kennis- en innovatieopgaven beschreven. De kennis- en innovatieopgaven geven invulling aan de witte vlekken die er op dit moment zijn.

\section{Artificial intelligence}

Artificial Intelligence (AI) biedt mogelijkheden om via zelflerende computers allerlei maatschappelijke opgaves slimmer en sneller op te pakken. Er zijn al voorbeelden waarbij AI een rol speelt, bijv. in beeldverwerking met deep learning, in search-text automation en in automatisch voorraadbeheer.

De nieuwe generatie AI zal leiden tot zelfdenkende systemen en robots die met behulp van observaties, data, analyse en interpretaties slimmer en autonomer worden en daarmee steeds meer mensen ondersteunen in specifieke taken.

Kennis- en innovatieopgaven voor artificial intelligence in de Agro-Horti-Water-Food-sector zijn:

- Datafusie / sensorfusie: data- en sensorintegratie met een koppeling naar actuatoren en robots om handelingen te kunnen verrichten leidend tot een volledig autonome sense - think - act cyclus. De ontwikkeling van nieuwe sensoren leidt tot de beschikbaarheid van veel en diverse gegevens. Om zelflerende systemen succesvol te kunnen ontwikkelen en valideren, is het opzetten van referentieen trainingsdatasets voor verschillende toepassingsdomeinen (bijv. precisielandbouw, monitoring biodiversiteit, fenotypering).

- Semantisch-verrijkte en explainable AI: AI in de zin van machine learning gedraagt zich normaalgesproken als een black box. Het kunnen verklaren wat AI doet en waarom is cruciaal voor het draagvlak en biedt daarnaast, grote kansen voor verbetering van AI. Door data uit geleerde modellen (bijv. via deep learning) te combineren met expliciete kennis kan het AI-systeem beslissingen uitleggen en verantwoording afleggen over deze beslissingen. Dit bevordert de acceptatie van en het vertrouwen in het AI-systeem, en maakt het mogelijk fouten vroegtijdig op te sporen en te corrigeren.

- $\quad$ Hybride AI: het AI-systeem kan leren door mensen te imiteren bij het uitvoeren van handelingen. Nadere ontwikkeling van reinforcement leren, leren door demonstratie en telerobotica is nodig om hybride AI in de praktijk te kunnen toepassen. Voordeel van deze vorm van AI is dat het systeem op basis van een veel kleinere dataset dan bij traditionele AI zich een taak kan eigen maken.

- $\quad$ Ethical AI: Naarmate AI een grotere, autonome rol speelt in de maatschappij worden de ethische implicaties relevanter. Dit geldt bij bijvoorbeeld advisering qua lifestyle, maar ook bij de behandeling van dieren in de dierhouderij. Bij de ontwikkeling van AI-systemen is het relevant om na te denken of de toepassing van een AI-systeem in een specifieke context wenselijk is: wordt er genoeg rekening gehouden met mens en dier om van een maatschappelijke meerwaarde te kunnen spreken.

\section{(Autonome) robots}

Robots zijn machines die semiautonoom of autonoom taken kunnen uitvoeren. In de agro-horti-waterfood sector vindt veel onderzoek plaats voor het kunnen inzetten van robots in de praktijk, bijvoorbeeld als sorteermachine, zelfsturend landbouwvoertuig, in de veredeling, of als oogstrobot.

De volgende stap op robotica-gebied gaat over een verregaande integratie van AI-systemen met robots, waardoor ze veel autonomer kunnen opereren, alleen of in groepen. Klassieke robots zullen evolueren van programmeerbare apparaten naar samenwerkende, leerbare en zelflerende systemen die omgeving-specifiek beslissingen kunnen nemen.

Kennis- en innovatieopgaven voor autonome robots in de Agro-Horti-Water-Food-sector zijn:

- $\quad$ Navigeren en handelen: het correct herkennen en interpreteren van situaties en producten zodat de robot zelfstandig kan navigeren en handelen. Dit vraagt om context-specifieke interpretatie van 
beschikbare data: wanneer gaat het goed, wanneer moet er worden ingegrepen. Hiermee komt bijv. autonome teelt en adaptieve handling \& packaging in beeld.

- Zachte en kwetsbare producten: planten, dieren, groente en fruit moeten voorzichtig worden behandeld om verwonding of beschadiging te voorkomen. Robots moeten tactiele feedback kunnen interpreteren om zonder beschadiging met natuurlijke materialen om te kunnen gaan.

- $\quad$ Robot-robot-interactie: robots leren van elkaar en voeren gezamenlijk en autonoom taken uit, ze begrijpen wat er nodig, mogelijk en wenselijk is en wanneer. Doel is te komen tot een zelfstandig opererend systeem met menselijke interventie beperkt tot een minimum (management by exception). Toepassingen bijvoorbeeld in de autonome kas, maar ook in de precisielandbouw en verwerkende industrie.

\section{Dataficatie, big data, modellen en digital twins}

In de gehele sector vindt een exponentiële groei van beschikbare data plaats. Er zijn steeds meer sensoren die data genereren, apparaten zijn via het Internet of Things steeds meer verbonden met elkaar, en big data technieken zorgen ervoor dat de data verwerkt kunnen worden en dat verbanden gevonden worden. Onderzoek heeft plaats gevonden op het gebied van big data analyse om gebruik te maken van al deze data voor betere beslissingen op bedrijfs- en ketenniveau.

De volgende stap in het onderzoek op het gebied van dataficatie, big data, modellen en digital twins is om datafusie uit te voeren, om de processen in de sector efficiënter, intelligenter, veiliger en adaptiever te maken. Dataficatie is een nieuwe strategie om waarde uit data te creëren. Dataficatie gaat verder dan het verzamelen en opslaan van data uit een veelheid van bronnen. Doordat er meer en meer gedetailleerde data over producten, grondstoffen, processen en context gemeten, verzameld en gekoppeld worden, kunnen niet alleen bestaande voorspellingsmodellen betere resultaten geven, maar kunnen ook geavanceerdere modellen gemaakt worden, die nog nauwkeuriger zijn en tevens robuuster zijn m.b.t. variërende inputdata. Digital twins is een begrip dat in deze richting past.

Kennis- en innovatieopgaven voor dataficatie, big data, modellen en digital twins in de Agro-HortiWater-Food-sector zijn:

- Datafusie: datafusie is het bij elkaar brengen van data en informatie van verschillende aard of uit verschillende bronnen, zodat deze data interpreteerbaar wordt voor allerlei analyses.

- Dataficatie: geautomatiseerd meten, verzamelen en koppelen van meer en meer gedetailleerde data over producten, grondstoffen, processen en context en benutten om geavanceerdere modellen te maken die nauwkeurig en robuust zijn t.a.v. variërende inputdata.

- $\quad$ FAIR-data (Findable, Accessible, Interoperable, Reusable): vindbaarheid en herbruikbaarheid van datasets en modellen verbeteren. Specifieke data uit slecht gestructureerde data halen (bijvoorbeeld van het web of uit legacy systemen).

- Emergente patronen: patronen ontdekken in big data op basis van statistische analyse of (hybride) AI technieken om zo tot nieuwe inzichten te komen voor betere beslissingen.

- Digital twins: Ontwikkelen van modellen (combinatie van statistische modellen, logische modellen en machine learning) om plant, dier, geoogst product, of verwerkingsproces digitaal te representeren om effecten van handelingen (bijv. op het gebied van smart farming of smart factory) te simuleren en zo snel en efficiënt het effect van beslissingen te kunnen doorrekenen.

- $\quad$ Triple A modellen: verdere ontwikkeling en uitbreiding van cruciale modellen in het agro-hortiwater-food domein.

\section{Datamodellering en standaarden}

Data-train en internet of things raken aan het verzamelen en analyseren van big data, zowel qua infrastructuur (van 5G tot empowered edge, van AI tot gedistribueerde rekenkracht) als qua ontwikkeling van concepten/methoden om met big data om te gaan: hoe zorg je dat alle apparaten die gekoppeld zijn aan de keten hun data goed verzamelen, goed opslaan en goed delen (push en pull van data), welke structuur breng je aan, wat is de rol van ontologieën en standaarden, etc. Het onderzoek op dit gebied is in volle gang. De stip op de horizon op het gebied van datamodellering is het ontwikkelen van methoden om automatisch relevante data van hoge kwaliteit te verzamelen. 
Kennis- en innovatieopgaven voor datamodellering en standaarden in de Agro-Horti-Water-Food-sector zijn:

- Draagvlak: ontwikkeling en creëren van draagvlak voor standaarden voor het uitwisselen en koppelen van datasets en modellen.

- Datakwaliteit: methoden en technieken voor het automatisch genereren, bewaken en verbeteren van datakwaliteit.

- Datastandaarden: open data platforms zoals Akkerweb en JoinData zijn voorbeelden van platforms die gebruik maken van goede datastandaarden. Ontwikkeling van dergelijke standaarden in andere delen van de Agro-Hort-Water-Food sector is gewenst.

\section{Decision support systemen}

Decision support systemen zijn systemen die worden gevoed met data en kennis om zo goed mogelijk een beslissing te kunnen nemen. Ook visualisatie-technieken, scenario-studies, monitoring \& control en simulaties vallen in deze categorie. Protocollen en SOPs kunnen ingebouwd worden in decision support systemen, zodat ze actiever kunnen worden toegepast.

Door de opkomst van dataficatie, internet of things en artificial intelligence worden de mogelijkheden van decision support systemen uitgebreid: beslissingsondersteuning zal in steeds complexere situaties mogelijk worden en steeds beter onderbouwd zijn met data en bewezen kennis.

Kennis- en innovatieopgaven voor decision support systemen in de Agro-Horti-Water-Food-sector zijn:

- $\quad$ VR en AR: het inzetten van virtual en augmented reality bij het maken van beslissingen en het visualiseren van what-if scenario's. Toepassing is bijvoorbeeld in augmented systems in precision farming.

- Integrale afweging: ontwikkelen van beslissingsondersteunende systemen die op basis van (combinaties van) nieuwe en eerder onbenutte data nieuwe inzichten genereren. Zwaartepunt ligt op integrale afweging, real-time monitoring, early warning systemen.

- Data op grote schaal: combineren van de beschikbare data in de keten van primaire sector tot retail om tot optimale besluiten te komen. Systemen ontwikkelen voor data- en kennisgebaseerde beslissingsondersteuning met als speerpunt: hoe kun je data over processen vroeg in de keten (veredeling, teelt, houderij) en data in de keten t.a.v. productvariatie gebruiken voor voorspellingen en beslissingen later in de keten? Toepassingsgebieden zijn bijv. breeding for quality, matching van vraag en aanbod om voedselverspilling te voorkomen.

\section{Mens-computer-omgeving interactie}

Computers ondersteunen mensen al geruime tijd met allerlei taken. De creatieve en context-bewuste mens wordt ondersteund met systemen die een bijna onbeperkt geheugen hebben, onbeperkt logisch kunnen doorredeneren, en onbeperkt beschikbaar zijn (24/7). De meeste mensen interacteren frequent met allerlei devices (smart phone, tablet, computer) en hebben real-time data tot hun beschikking om beslissingen op te baseren.

Door de ontwikkeling van kunstmatige intelligentie wordt de relatie tussen mens en machine intensiever. De ontwikkeling van 'smart spaces ${ }^{32}$ ', ecosystemen waarin mensen en computers interacteren met hun omgeving is de volgende stap. Hier komen ontwikkelingen op het gebied van Internet of Things, Artificial Intelligence, sensoren en robots samen. Menselijke en kunstmatige intelligentie versterken elkaar door de sterke punten van mensen (creativiteit, flexibiliteit, context-awareness) en machines (logisch redeneren, $24 / 7$ online, mogelijkheid om veel data te behappen) met elkaar te combineren.

De steeds grotere inzet van computers en robots in het arbeidsproces heeft echter niet alleen positieve kanten. De impact van robotisering is groot op de arbeiders die overblijven in het proces. Het werkklimaat verandert en kan onaangenamer worden voor de mens (hoge temperaturen in kassen die

\footnotetext{
${ }^{32}$ https://www.gartner.com/smarterwithgartner/gartner-top-10-strategic-technology-trends-for-2019/
} 
met gesloten ramen opereren), de sociale interactie tijdens het werk wordt minder, het werk wordt eentoniger, arbeiders lopen weg. Dit is een vraagstuk dat aandacht behoeft; door dit aspect mee te nemen in de verdergaande automatisering en digitalisering, kan een gebalanceerde implementatie worden gerealiseerd in deze vorm van mens-computer-omgeving samenwerking met aandacht voor alle 4 P's: people, profit, planet en prosperity.

Kennis- en innovatieopgaven voor mens-computer interactie in de Agro-Horti-Water-Food-sector zijn:

- $\quad$ Smart spaces: ontwikkeling van 'smart spaces': systemen waarin mens en machine gezamenlijk observeren, beslissen en handelen met speciale aandacht voor samenwerking met vele actoren, optimale taakverdeling, integrale afweging voor het bereiken van optimale beslissingen in elke relevante context.

- $\quad$ Reinforcement learning / learning by demonstration: ontwikkelen en toepassen van methoden die gebruik maken van het menselijk vermogen complexe taken uit te voeren in het agro-horti-waterfood domein, dit te laten observeren door artificial intelligence systemen en daardoor de kennisoverdracht van mens op machine te versnellen.

- Citizen science: ontwikkelen van methoden om consumenten in te zetten om data te verzamelen voor onderzoek. De verzamelde gegevens kunnen weer met behulp van AI geanalyseerd worden. Op deze manier raakt de burger betrokken bij onderzoek en bij de verdere ontwikkeling van artificial intelligence. Voorbeelden op dit gebied liggen bijv. op het vlak van natuurwaarnemingen door consumenten ${ }^{33}$.

- Auditieve interactie: interactie tussen mens en machine gebeurt nu nog grotendeels via een toetsenbord. De mogelijkheden van taal als interactiemedium nemen toe. Het grote voordeel in de agro-horti-water-food sector is dat via spraak-interactie de handen vrij zijn voor het uitvoeren van taken.

\section{Non-destructieve metingen}

Al geruime tijd wordt gewerkt aan het bepalen van eigenschappen van gewassen, veestapel, populaties of productbatches. De behoefte is er echter, bijv. gevoed vanuit de doelstellingen van de precisielandbouw maar ook uit de noodzaak om voedselverliezen terug te dringen, om op veel individuelere schaal te gaan meten. Idealiter worden eigenschappen op individueel plant, dier, mens of productniveau bepaald zodat precisielandbouw, precisiehouderij, gepersonaliseerd advies en kwaliteitsmetingen precies kunnen plaats vinden.

Hierbij is het wenselijk dat de meting op niet-destructieve en niet-invasieve wijze plaatsvindt. Daardoor wordt dieren- en mensenwelzijn gediend, en gaan planten en producten niet verloren door het uitvoeren van de meting. Er zijn verschillende non-destructieve en niet-invasieve meettechnologieën voorhanden, denk bijv. aan NIR/VIS, X-ray, volatile-analyse, maar de koppeling tussen het meetresultaat en de te meten eigenschap wordt voornamelijk via correlaties indirect bepaald en is daardoor groep-specifiek en minder betrouwbaar dan gewenst.

Kennis- en innovatieopgaven voor non-destructieve en non-invasieve metingen in de Agro-Horti-WaterFood-sector zijn:

- Meetmethode: Onderzoeken welke (combinatie van) niet-destructieve en niet-invasieve meettechnologieën (NIR/VIS, XRT, THz, MRI, 2D/3D, volatiles, biomarkers, ...) in real-time een specifieke product/plant/ dier/mens-eigenschap real-time kan meten.

- Modellering: ontwikkelen van onderbouwde modellen om de gemeten data te koppelen aan product/ plant/dier/mens-eigenschappen en zo op individueel niveau een uitspraak te doen over de te verwachten invloed van omstandigheden en de mogelijke effecten van een ingreep.

\footnotetext{
${ }^{33}$ https://waarneming.nl/pages/getting-started/
} 


\section{Sensoren}

Sensoren zijn in alle soorten en maten beschikbaar gekomen voor toepassing in het agro-horti-waterfooddomein. Hiermee kunnen in principe on-site, hoogfrequente en nauwkeurige metingen worden gedaan. De sensoren zijn veelal gekoppeld aan het internet of things, waardoor ze real-time data kunnen opleveren voor nadere analyse, voorspelling en decision support.

De uitdaging op sensorgebied is dat de toepassing in de agro-horti-water-foodsector vaak vraagt om sensoren die in niet-laboratoriumomstandigheden kunnen functioneren. Het veld kan modderig zijn, vertical farminglocaties hebben specifieke lichtcondities, de stal is vies en stoffig, leidingen zijn nat, en productieomstandigheden zijn koud of heet. Sensoren zijn daar niet bij voorbaat voor geschikt, waardoor er nog een herontwerp van de sensoren nodig is voor ze toepassingsrijp zijn. Vaak is miniaturisering van de sensor nodig om geschikt te zijn voor een specifieke toepassing.

Kennis- en innovatieopgaven voor sensoren in de Agro-Horti-Water-Food-sector zijn:

- Sensoren van lab naar praktijk: Ontwikkelingen van sensoren die on-site en autonoom metingen kunnen doen, ook in praktijkomstandigheden die technologisch uitdagend zijn (nat, koud, vies, ...). Toepassen van nieuwe sensoren die directe kwaliteitsparameters kunnen meten (bijv. concentratie, uniformiteit, vervuiling). Dit leidt tot minder water en energie-input in het food processing proces.

- $\quad$ Nieuwe sensoren: Ontwikkeling van nieuwe sensoren gericht op het begrijpen en monitoren van gewasfysiologie, -groei en -ontwikkeling; ontwikkeling nieuwe principes voor het niet-invasief meten van gezondheidsstatus (bijvoorbeeld via het 'slimme toilet'); sensoren voor het herkennen van vluchtige stoffen en aroma's (e-nose); evidence-based sensing.

- Sensorfusion: Ontwikkeling van zelflerende netwerken van sensors en soft sensors, alarmeringssystemen op basis van data mining algoritmes (zowel fore-casting als back-casting). Daarnaast ontwikkeling van nieuwe lichte en pervasive sensorsystemen - waaronder micro- en nanobots - gericht op indoor-navigatie, energiegebruik, emissies en koolstof-opslag ten behoeve van precisielandbouw, precisiedierhouderij en precisieverwerking. Tot slot ontwikkeling van multisensor fenotyperingstechnieken om gewas- en diereigenschappen, ziekten en plagen non-invasief en kwaliteit van voedsel geautomatiseerd kwantitatief te kunnen beoordelen.

\subsection{Technologie-toepassingen in het lopend onderzoek}

In deze paragraaf worden de technologie-toepassingen belicht die in de verschillende missies zijn ondergebracht. Smart technology biedt hier innovatieve kansen om de missie-gerelateerde onderwerpen een stap voorwaarts te brengen voornamelijk via implementatie en demonstratie, en in lichte mate via toegepast onderzoek.

Als je kijkt naar de maatschappelijke opgaven, dan is de noodzaak voor ontwikkeling op de volgende onderwerpen hoog (zie Tabel 1, pagina 19): smart farming / precision farming, food waste \& loss prevention \& reduction, water-land-energy-food nexus / smart water systems, monitoring biodiversiteit, personalised healthy \& sustainable food, last mile / e-commerce, trusted food supply chains, autonomous handling \& packaging, adaptive food processing, fenotypering and adaptive horticulture.

Op elk van deze onderwerpen is de afgelopen jaren veel ontwikkeld en zijn grote stappen voorwaarts gemaakt. De technologie ontwikkelt zich echter snel en nieuwe stippen op de horizon verschijnen voor deze onderwerpen. Dat betekent dat ook op deze op zich al bekende onderwerpen zich witte vlekken voordoen in het onderzoek. Deze onderwerpen worden door de ontwikkelingen op het gebied van 'Smart Technology' verder gebracht, waardoor de ambities vanuit de zes LWV-missies stapsgewijs gerealiseerd kunnen worden.

Precision farming -- precision farming houdt zich bezig met het maken van gedetailleerde en geïntegreerde beslissingen in de agro-horti-water-food sector gebaseerd op temporele, spatiële en plant/dier/product/omgeving-specifieke data met als doel het gebruik van inputs te minimaliseren en productiviteit, winst, duurzaamheid en kwaliteit te maximaliseren. De witte vlekken op het gebied van 'smart technologies' voor smart farming zitten op de volgende onderwerpen: 
- Ontwikkeling van autonome landbouwvoertuigen en drones: het arbeidsintensieve proces van precision farming heeft ondersteuning nodig van autonome landbouwvoertuigen voor toediening van inputs en drones voor inspectie van de status van plant of dier.

- $\quad$ Ontwikkeling van nieuwe lichte sensorsystemen - waaronder micro- en nanobots - gericht op indoornavigatie en het minimaliseren van energiegebruik, emissies en koolstof-opslag. Hiermee wordt het concept van precision farming efficiënter en winstgevender.

- $\quad$ Ontwikkelen van methodes voor het meetbaar maken en managen van dierwelzijn, diergezondheid en biodiversiteit in verschillende omgevingen met aandacht voor productdifferentiatie en kringloop denken.

Food waste prevention \& reduction -- om voedselverspilling van de primaire sector tot en met consument daadwerkelijk terug te dringen met de benodigde $50 \%$ zijn veel soorten maatregelen nodig. 'Smart technologies' kunnen een rol spelen in het automatisch meten van voedselverspilling:

- $\quad$ Ontwikkelen van computer vision algoritmen en sensorsystemen voor het nauwkeurig automatisch meten van voedselverlies in de gehele keten van veredeling tot consument.

- Ontwikkelen data-sharing methoden om data door de hele voedselketen veilig en vertrouwd te kunnen delen om zo vraag en aanbod beter op elkaar af te stemmen en hiermee verspilling te voorkomen.

- $\quad$ Ontwikkeling van data-uitwisseling en beslissingsondersteuning op basis van optimalisatiemodellen.

- $\quad$ Smart kitchen: inzet van Internet of Things technologie, zodat de koelkast weet welke ingrediënten nog aanwezig zijn in de koelkast en de consument alert kan maken op naderende THToverschrijdingen, suggesties kan doen voor recepten. De smart kitchen kan ook helpen met het op maat autonoom en online bestellen van producten die passen bij het gezin in kwestie, zodat op maat kan worden gekookt. Dit draagt bij aan minder verspilling bij de consument thuis.

Water-Land-Energy-Food nexus/Smart water systems -- de beschikbaarheid van water op de gewenste plaats en op het gewenste moment, wordt in de toekomst minder vanzelfsprekend. Slimme technologieën die vraag en aanbod van (rest)waterstromen met elkaar verbinden kunnen inspelen op de toenemende vraag naar (proces)water. de witte vlekken op het gebied van 'smart technologies' voor water-land-energy-food nexus en smart water systems zitten op de volgende onderwerpen:

- Ontwikkeling van geavanceerde 'on site' en 'real time' meettechnologieën voor waterkwaliteit en waterzekerheid: slimme en snelle detectiemethoden.

- $\quad$ Ontwikkelen van modellen die opbrengst van zuiveringsinstallaties voorspellen met aandacht voor natuur-gebaseerde technologieën (green liver), membraanvervuilingen, zandfilters, tweede generatie korrelslib reactoren, etc.

- $\quad$ Ontwikkeling van zelflerende netwerken van sensors en soft sensors, alarmeringssystemen op basis van data mining algoritmes (zowel forecasting als backcasting).

Monitoring Biodiversiteit -- biodiversiteit speelt een rol op het water en op het land, het gaat over monitoren van flora en fauna, over onderscheid tussen natuur en cultuur. Veel monitoring vindt op dit moment met de hand plaats door experts. Hier kan 'smart technology' een belangrijke digitaliseringsslag helpen realiseren:

- $\quad$ Ontwikkelen methodiek voor automatische detectie en tellingen van indicator soorten.

- Ontwikkelen van de combinatie van Artificial Intelligence technieken, beeld herkenning en citizen science voor de interactieve ontsluiting van biodiversiteits-prestaties (van de landbouw).

- Ontwikkelen van methoden voor datafusie van veel verschillende on-site remote sensing databronnen (bijv. Sentinel 1, Sentinel 2, Landsat) voor biodiversiteitsmonitoring. 
Personalised nutrition -- dit is een onderwerp dat ontstaan is doordat het de laatste jaren steeds normaler is geworden om self-monitoring apparaten te gebruiken (bijv. bloeddrukmeters, stappentellers, maar ook geïmplanteerde chips voor diabetespatiënten) om allerlei voeding- en leefstijlgerelateerde parameters vast te stellen. Ook zijn er steeds meer aanbieders die consumenten ondersteuning bieden in het kiezen van een ander dieet. De uitdaging ligt op het verzorgen van gevalideerde informatie aan de consument en op verregaande integratie van aanwezige data en kennis:

- $\quad$ Ontwikkelen van wetenschappelijk-onderbouwd Digital Dietary Advice kan worden gegeven op basis van verzamelde gezondheidsinformatie / levensstijl (o.a. door steeds geavanceerde human sensoring) en modellen van kennis over interactie tussen voeding en gezondheid.

- $\quad$ Ontwikkeling nieuwe principes voor het niet-invasief meten van gezondheidsstatus (bijvoorbeeld via het 'slimme toilet').

- Ontwikkeling nieuwe principes voor het niet-invasief meten van voedselinname, zowel via gedragsobservatie als biomarkers in het lichaam.

- Ontwikkelen van methodes voor het printen van gepersonaliseerde voeding met complexe structuren en functionele producteigenschappen.

Overigens is het naast het aanbieden van gepersonaliseerd advies over gezonde voeding met dezelfde technologie mogelijk om gepersonaliseerd advies over duurzame voeding aan te bieden.

Last mile /e-commerce -- de algemene verwachting is dat het retailkanaal steeds meer gaat verschuiven van de fysieke wereld naar een online winkel. Dit heeft allerlei impact op het last-mile en e-commerce vlak. De witte vlekken zitten op:

- $\quad$ Ontwikkeling van universeel concept waarbij last mile van alle aanbieders van online (vers en vries) bestellingen gezamenlijk en emissieloos bezorgd kunnen worden.

- Ontwikkelen van adaptieve zero emissie geconditioneerde bezorgwagen/fietsaanhanger, die de specifieke transportvolume en koudevraag van de bestellingen optimaliseert.

Trusted food supply chains -- informatie over herkomst van producten voor de consument en datauitwisseling tussen verschillende partijen zijn beide elementen die belangrijk zijn in een agrofood supply chain waar vertrouwen een belangrijke factor is. 'Smart technology' is erop gericht dit vertrouwen te vergroten via de volgende innovatie-opgaven:

- Ontwikkelen van methode voor privacy-veilige en concurrentie-veilige ketentransparantie door linked data standaarden en blockchains en blockchain-gelijkende technieken toe te passen in de supply chain inclusief het primaire proces (Linked Food Data).

- Ontwikkeling van het concept 'true transparency' op basis van data-uitwisseling in combinatie met beslissingsondersteuning, als alternatief voor certificering.

- Ontwikkelen van methoden voor datafusie van data uit verschillende soorten databronnen voor het kunnen voorspellen van emerging risks en food safety hazards in de keten.

Autonomous handling \& packaging -- in de verwerking van verse voedselstromen is het lastig mensen te krijgen voor inspecteer-, sorteer- en verpakkinsgwerkzaamheden. Artificial intelligence, nondestructieve meetmethoden en robotisering bieden oplossingen voor het omgaan met kwetsbare producten die op hoge snelheid door het proces gaan.

- Ontwikkelen van slimme camerasystemen die op een robuuste manier de vorm, kwaliteit en aangrijpingspunten van producten met hoge nauwkeurigheid en snelheid kunnen herkennen om producten met variabele vorm en gewicht autonoom te kunnen grijpen en verplaatsen voor sorteer-, verwerkings- en verpakkingstoepassingen.

- Onderzoeken welke (combinatie van) non-destructieve meettechnologieën (NIR/VIS, XRT, THz, MRI, 2D/3D, ...) een specifieke product/plant/diereigenschap real-time kan meten; ontwikkelen van onderbouwde modellen om de gemeten data te koppelen aan product/plant/diereigenschappen. 
Adaptive food processing -- Voedselproductie is in hoge mate geoptimaliseerd op kostenreductie via procesefficiëntie. De sturing van de onderliggende productieprocessen is op vergelijkbare wijze geoptimaliseerd, d.w.z. massaproductie met een hoge mate van standaardisatie en gebruik van goedkope grondstoffen in sterk gezuiverde vorm. Een doorbraak naar een meer duurzaam voedselproductie-systeem kan alleen tot stand komen als er specificaties aan het eindproduct worden gesteld, waarin ook aspecten als gezondheid, CO2-footprint en dierenwelzijn worden meegenomen. Smart technologies spelen een rol in deze verduurzaming via nieuwe sensoren en digital twins.

- Ontwikkelen en toepassen van nieuwe sensoren die directe kwaliteitsparameters kunnen meten (bijv. concentratie, uniformiteit, vervuiling) i.p.v. alleen zuiverheid. Dit leidt tot minder water en energie-input in het food processing proces.

- Ontwikkelen van digital twin modellen om de relatie tussen grondstof, proces en eindproduct te kunnen simuleren. Daardoor kunnen productietechnologieën worden ontwikkeld die het maken van kleinere productseries mogelijk maken (quick change-overs) en die beter met variatie van grondstoffen kunnen omgaan (reststroomverwaarding).

Fenotypering -- Om een significante bijdrage te kunnen leveren aan het veiligstellen van de toekomstige wereldwijde voedselproductie, en om de concurrentiepositie van Nederland op het gebied van veredeling van land- en tuinbouwgewassen en ook productiedieren te bestendigen, is er een grote behoefte aan inzichten hoe de interactie tussen genotype en fenotype (de fysiologische en biochemische kenmerken van organismen) plaatsvindt, zodat de genen die zorgen voor optimale eigenschappen geïdentificeerd kunnen worden. Voor deze zogenaamde 'precision fenotypering' is een scala aan high tech technologieën nodig om uit- en inwendige kenmerken van organismen in verschillenden stadia snel en geautomatiseerd te kunnen meten vanuit hoge resolutie detailanalyse. De volgende tooling is gewenst:

- Ontwikkeling van multi-sensor fenotyperingstechnieken om gewas- en diereigenschappen, ziekten en plagen non-invasief en kwaliteit van voedsel geautomatiseerd kwantitatief te kunnen beoordelen.

- Onderzoeken welke (combinatie van) non-destructieve meettechnologieën (NIR/VIS, XRT, THz, MRI, 2D/3D, ...) een specifieke product/plant/diereigenschap real-time kan meten; ontwikkelen van onderbouwde modellen om de gemeten data te koppelen aan product/plant/diereigenschappen.

- Ontwikkelen van modellen en AI technieken om autonoom opererende en lerende machines en/of robots voor fenotyperende handelingen in open teelten, kassen en in dierhouderij systemen te realiseren voor gebruik in de praktijk (high speed throughput, heldere classificatie, toetsbare resultaten).

Overigens is het onderwerp fenotyperong in het domein van de veredeling ook relevant. Daarbij wordt de techniek meer gebruikt in het onderzoek om specifieke genotypes en DNA merkers op te sporen, terwijl vanuit Smart Technology fenotyperingstoepassingen worden ontwikkeld voor met name high throughput toepassingen om de juiste fenotypes te kunnen opsporen.

Adaptive horticulture -- Wereldwijd is de huidige groei van glastuinbouw meer dan $10 \%$ per jaar en de verwachting is dat deze trend doorzet (hierbij gaat het om alle vormen van low tech tot high tech protection). Om greenhouse technology wereldwijd tot een succes te maken zijn een goede, lokale toeleverende industrie en gekwalificeerde telers, naast toegang tot de benodigde kennis, cruciale elementen. Met behulp van adaptive horticulture wordt technologie aangepast aan lokale klimaat- en marktomstandigheden en tegelijkertijd wordt stapsgewijs de benodigde kennis en kunde van telers, adviseurs en toeleverende industrie ontwikkeld. Door op afstand systemen uit te lezen kunnen deskundigen over de schouder meekijken en adequaat interveniëren bij problemen. Low tech en mid tech oplossingen kunnen al een enorme productieverhoging realiseren. High tech oplossingen leveren energiebesparing, emissiereductie, slimme waterhuishouding.

- Ontwikkeling van indoor autonome robots voor het uitvoeren van teelthandelingen en het diagnosticeren van het gewas. 
- Onderzoek naar verbeterde simulatiemodellen voor kasklimaat, energie- en waterverbruik in verschillende buitenomstandigheden, doorontwikkeling van bestaande klimaat en gewasproductiemodellen, en integratie van verschillende modellen, uitbreiding met nieuwe kennis (bijv. LED belichting, 3D gewasgroei etc.)

- Ontwikkeling van nieuwe vroegtijdige detectiemethodes voor gewasweerbaarheid, ziekttes, plagen en biologische bestrijders.

- Ontwikkeling van nieuwe sensoren gericht op het begrijpen en monitoren van gewasfysiologie, groei, ontwikkeling.

\subsection{Technologische trendanalyses}

De voorgaande paragrafen behandelden de witte vlekken en kennis- en innovatieopgaven vanuit het lopende onderzoek. Om te voorkomen dat kansrijke innovaties op het gebied van Smart Technology over het hoofd worden gezien, is het van belang om ook van buitenaf naar het Smart Technology domein te kijken en te identificeren of er kansen liggen voor het Agro-Horti-Water-Food domein die op dit moment nog niet belegd zijn in het onderzoek.

Voor deze paragraaf hebben we vier technologische trendanalyses gebruikt: van Gartner, ING, Accenture en Deloitte. Elk van deze bedrijven heeft het technologie-domein vanuit een andere invalshoek benadert en komt tot een overzicht van trends. In paragraaf 4.3.5 trekken we de conclusie uit deze technologische trendanalyses met betrekking tot de witte vlekken in het Smart Technology in Agro-Horti-Water-Food onderzoek.

\subsubsection{Technologische trends volgens Gartner}

Gartner brengt jaarlijkse een technologische trendanalyse uit. In de trendvoorspelling voor $2019^{34}$ worden de volgende tien trends genoemd:

- $\quad$ Autonome dingen: auto's, robots, drones, apparaten en intelligent agents gaan steeds meer taken van mensen overnemen en zijn daar autonoom in. Daarvoor wordt Artificial Intelligence gebruikt om autonoom of semiautonoom de interactie met de omgeving aan te gaan (sense-think-act). Voorlopig zit de ontwikkeling op het uitvoeren van goed gespecificeerde taken.

- $\quad$ Augmented analytics: verder gebruik van machine learning om big data analyse geautomatiseerd uit te kunnen voeren. De hoeveelheid aan data is zo groot, dat de noodzaak om deze zonder menselijke tussenkomst te analyseren groeit.

- $\quad$ AI-gedreven software ontwikkeling: Gartner verwacht dat het voor software ontwikkelaars steeds eenvoudiger wordt om artificial intelligence functionaliteit in software in te bouwen, zonder dat daar data scientists aan te pas hoeven te komen.

- Digital twins: digital twins zijn representaties van fysieke entiteiten in de digitale wereld. Trend is dat ze steeds meer worden ingezet als tool om real-time monitoring uit te voeren en processen te optimaliseren.

- Empowered edge: dankzij het internet of things (IOT) is er veel data beschikbaar. Om daar snel op te acteren, wordt de 'edge' van het IoT gebruikt. De 'edge' refereert daarmee aan de apparaten die in de wereld om ons heen gebruikt worden. Het dataverkeer hoeft niet verplaatst te worden naar een centrale server, maar wordt juist op de apparaten zelf zoveel mogelijk verwerkt.

- Immersive experience: virtual reality en augmented reality veranderen de manier waarop mensen en intelligent agents met elkaar interacteren. Deep learning stelt kunstmatige intelligentie in staat om natuurlijkere interacties te hebben met mensen.

- Blockchains: blockchains maken vertrouwen in de keten mogelijk, kunnen transparantie faciliteren en hebben daarmee de mogelijkheid om toegang tot de globale markt voor iedereen mogelijk te maken.

\footnotetext{
${ }^{34}$ https://www.gartner.com/smarterwithgartner/gartner-top-10-strategic-technology-trends-for-2019/
} 
- $\quad$ Smart spaces: een smart space is een fysieke of digitale wereld waarin mensen en kunstmatige intelligenties op een volwaardige manier met elkaar samenwerken. Mensen leren van machines, machines leren van mensen.

- Digitale ethiek en privacy: in het domein van de privacy zal een verschuiving plaatsvinden van de vraag "voldoen we aan de wet- en regelgeving" naar "doen we het moreel juiste". Dit is voor bedrijven essentieel om het vertrouwen van de consument te behouden.

- Quantum computing: Gartner ziet ontwikkelingen op het gebied van quantum computers, maar voorspelt dat echte toepassingen pas later komend decennium zullen worden ontwikkeld.

\subsubsection{De potentie van robotisering volgens ING Bank}

In februari 2019 heeft ING Economisch Bureau een folder uitgebracht waarin de potentie van robotisering voor de voedingsindustrie werd belicht ${ }^{35}$. Robotisering, digitalisering en kunstmatige intelligentie, nieuwe verwerkingstechnieken, 3D food printing, nanotechnologie en celtechnologie werden genoemd als veelbelovende foodtech toepassingen. Precisielandbouw, veredelingstechnieken, aquacultuur, kringlooplandbouw, productie van nieuwe eiwitbronnen en biotechnologie worden genoemd als onderwerpen in agritech. In Figuur 12 is deze set onderwerpen weergegeven.

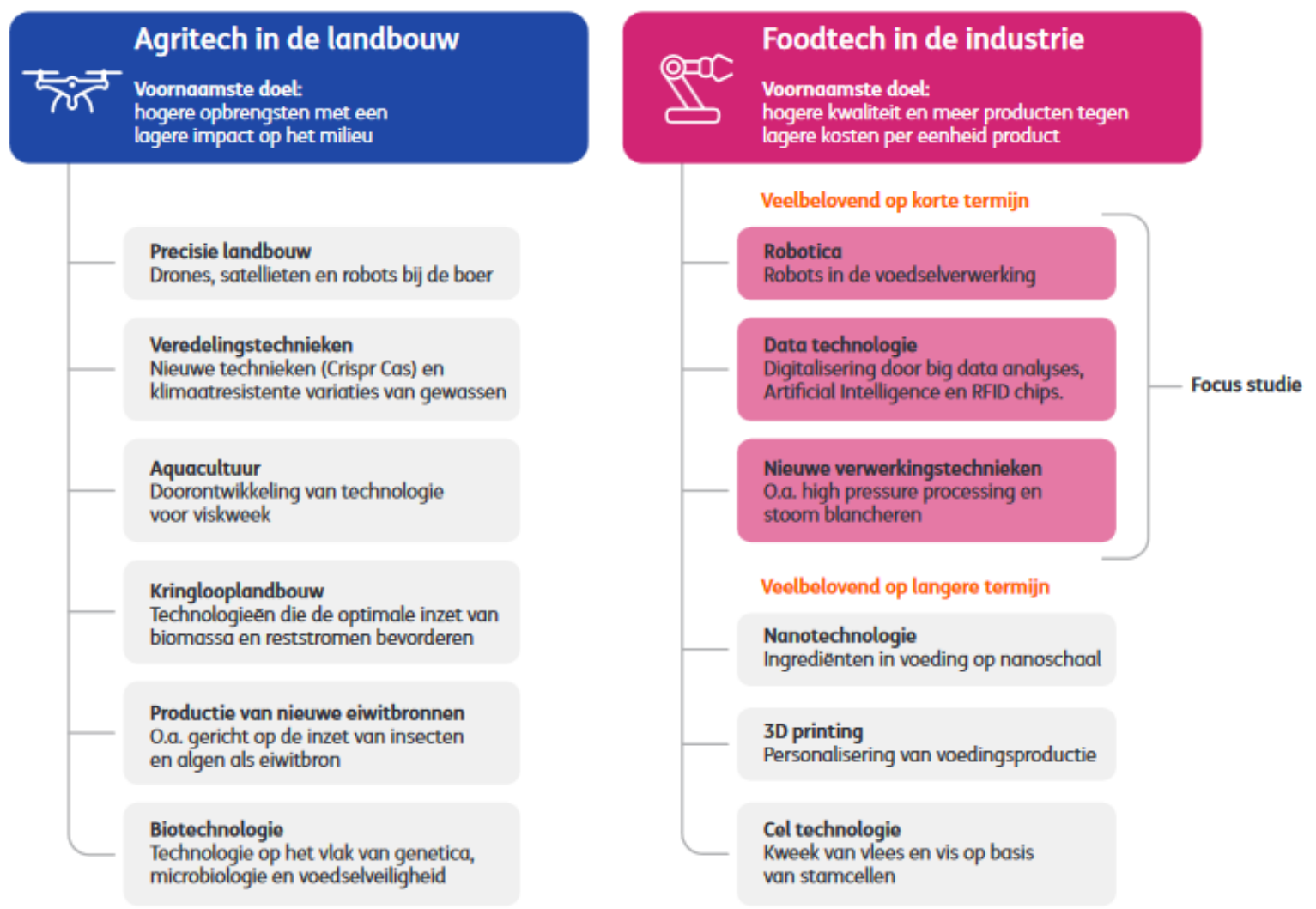

Figuur 12: Overzicht van foodtech volgens de publicatie van ING Economisch Bureau.

\subsubsection{Tech-trends volgens Accenture}

Accenture heeft in februari 2019 een technologie-visie gepubliceerd ${ }^{36}$, waarin zij vijf technologische trends voor de post-digitale wereld definiëren. Accenture gaat uit van het standpunt dat de meeste bedrijven al een digitaliseringsslag hebben doorgemaakt en bereikbaar zijn via website en social media. Zij verwachten dat de markt zich steeds meer als een individuele markt gaat ontwikkelen, waar consumenten on demand en gepersonaliseerde diensten en producten wensen af te nemen. Internet of things helpt daarbij, doordat digitale diensten op die manier niet meer aan een computer gebonden zijn,

\footnotetext{
35 https://www.ing.nl/media/pdf_ING-Foodtech-Robotarm-biedt-voedingsindustrie-de-helpende-hand-februari2019_tcm162-165693.pdf

36 https://www.accenture-insights.nl/nl-nl/artikelen/technology-vision-2019-5-trends-post-digitale-wereld
} 
maar via alle apparaten die online toegankelijk zijn geworden. Tegelijkertijd worden nieuwe technologische ontwikkelingen in een sneltreinvaart omarmd: "Na de introductie van de mobiele telefoon duurde het twaalf jaar om 50 miljoen gebruikers te bereiken. Het internet had maar zeven jaar nodig om hetzelfde punt te bereiken. En als we naar digitale technologieën kijken, is het tempo adembenemend. Facebook had binnen drie jaar 50 miljoen gebruikers en WeChat haalde dat al binnen een jaar. Augmented reality game Pokemon GO bereikte dat aantal in slechts 19 dagen". Privacy, veiligheid, ethiek en aansturing zijn elementen die aandacht behoeven.

De trends die Accenture ontwaart, zijn:

- 'DARQ': Distributed ledger-technologie, artificial intelligence, extended reality en quantum computing (DARQ) zijn technologieën die bedrijven in staat stellen om hun sector opnieuw uit te vinden.

- $\quad$ Kennis van je klant: gepersonaliseerde relaties tussen bedrijven en consumenten kunnen ontstaan doordat technologie het bedrijf in staat stelt de consument en zijn/haar behoeftes te begrijpen.

- 'Mens+' medewerkers: elke individu heeft zijn eigen vaardigheden en kennis, aangevuld met een set mogelijkheden die door technologie wordt aangejaagd. Het is aan bedrijven om hun technologiestrategieën, die aan de basis van de nieuwe generatie medewerkers staat, aan te passen.

- $\quad$ Beveiliging als standaard onderdeel van het ecosysteem dat bedrijven onderling en met hun klanten verbinden.

- Momentmarkten: technologie creëert een intense wereld van op maat gesneden en on-demand ervaringen, de markt verandert in een individu-gerichte just-in-time markt.

\subsubsection{Tech-trends volgens Deloitte}

Deloitte heeft voor 2019 hun $10^{\mathrm{e}}$ Tech Trends rapport uitgebracht, waarin ze de huidige trends in digitale technologie koppelen aan de ontwikkelingen uit het recente verleden ${ }^{37}$. Hieruit volgen zes ontwikkellijnen op het gebied van tech-trends (zie Figuur 13):

- $\quad$ AI-fuelled organisaties: AI zal zich ontwikkelen van de huidige assisted intelligence via augmented intelligence (ook wel hybride AI) naar vol-autonome AI. Als cognitieve tools en dataopslag steeds meer worden gestandaardiseerd tussen IT-systemen, wordt het gemakkelijk voor AI om samen te werken met mensen in werkomgevingen.

- $\quad$ NoOps in een serverloze wereld: software wordt functie-gedreven en is via de cloud op vraag af te nemen en op te schalen. Daardoor wordt het vernieuwen van de bedrijfssoftware eenvoudiger en goedkoper.

- Connectivity: internet of things, blockchains, 5G en edge computing maken het mogelijk om op grote schaal netwerken te benutten. Big data wordt gegenereerd. Via connectivity wordt het mogelijk om op een efficiënte manier de data te verwerken en te transporteren naar de plek waar de interpretatie van de data nodig is.

- $\quad$ Intelligente interfaces: de noodzaak om na te denken over hoe mensen, machines en data met elkaar interacteren. Technologieën om met systemen te communiceren verschuiven van keyboard naar touch screen, spraakinterfaces, AR en VR interfaces en zelfs camerasystemen voor emotiedetectie. Intelligente interfaces zorgen ervoor dat de manier waarop mensen en machines met elkaar communiceren radicaal gaan veranderen.

- $\quad$ Personalised en contextualised marketing: bedrijven zullen consumenten steeds meer als individu in plaats van als lid van een consumentensegment gaan benaderen. Hiermee verandert de supply chain van push naar pull.

\footnotetext{
${ }^{37}$ https://www2.deloitte.com/content/dam/insights/us/articles/Tech-Trends-2019/ DI_TechTrends 2019.pdf
} 


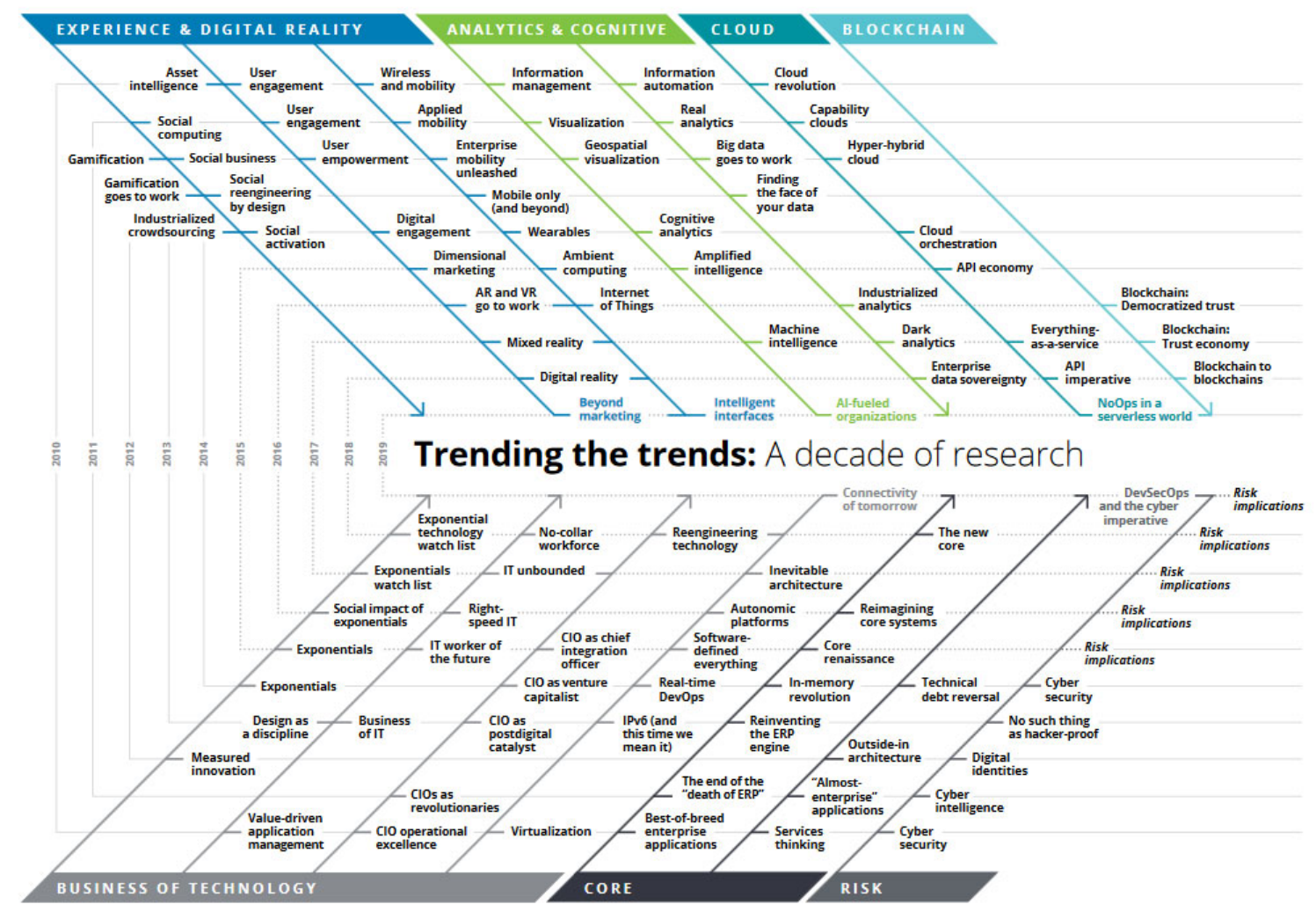

Figuur 13: Tech-trends volgens Deloitte. (Bron: zie voetnoot 37).

\subsubsection{Conclusie}

Wat uit de bovenstaande vier technologische trendanalyses duidelijk wordt is dat er veel staat te gebeuren op het gebied van smart technology.

\section{Witte vlekken}

Artificial intelligence is een trend die zich voortzet, waarbij human-computer interactie essentieel wordt: Gartner noemt het smart spaces, Deloitte beschrijft intelligente interfaces, bij Accenture zie je het terug in de extended reality (onderdeel van DARQ) en ING ligt dit aspect toe in het rapport bij het onderwerp Robotica. In het Agro-Horti-Water-Food domein ligt op het onderwerp hybride AI veel potentie. Tot nu toe komt het niet in het lopend onderzoek op grote schaal naar voren. Dit onderwerp is een witte vlek op het gebied van Smart Technology in Agro-Horti-Water-Food. Om deze witte vlek in te kunnen vullen zijn andere genoemde trends relevant, zoals de ontwikkeling van autonome robots, augmented analytics, data technologie en immersive experience.

\section{Onderwerpen die terugkomen in het huidige onderzoek}

Blockchains worden genoemd door Gartner en Accenture ('distributed ledger technology'). Deze technologie vindt in het LWV-domein ook haar weerslag in o.a. missie $D$, waar het om vertrouwen in de keten gaat. Gepersonaliseerde voeding is ook in missie $D$ te vinden.

\section{Trends die buiten de scope van de programmeringsstudie vallen}

Veranderingen in de manier waarop software wordt ontwikkeld wordt ook in meerdere trendanalyses genoemd (Gartner, Deloitte). Voor de scope van deze studie is deze trend niet van toepassing. We verwachten wel dat deze technologieontwikkeling op termijn de manier waarop softwaresystemen in het LWV-domein ontworpen worden zal veranderen. We zien echter geen ontwikkeling op dit gebied die specifiek zijn voor de cross-over met het Agro-Horti-Water-Food domein.

Ook voor de empowered edge trend geldt dat dit een technologieontwikkeling is, waar het LWV-domein van gaat profiteren zodra het beschikbaar komt, maar waar vanuit het domein geen specifieke onderzoeksvragen voor zijn. 
Gartner en Accenture noemen quantum computing als technologie die op lange termijn resultaten zal gaan opleveren. Voor het Agro-Horti-Water-Food domein is dit op een te laag TRL-niveau om op dit moment als witte vlek geïdentificeerd te worden.

Digitale ethiek, privacy, beveiliging zijn societal en economic concerns waar dit hoofdstuk mee opende. Waar het het Agro-Horti-Water-Food-domein raakt, wordt het onderwerp behandeld. Op puur technologisch vlak, valt het onderwerp buiten de scope van deze programmeringsstudie. 


\section{Interesse bedrijfsleven}

Om de interesse voor de verschillende deelonderwerpen binnen 'Smart Technology in Agro-Horti-Water-Food' te peilen bij het bedrijfsleven, is een enquête uitgezet bij 18 koepelorganisaties en 32 bedrijven. Deze partijen komen uit het gehele domein. Er zijn partijen die met name opereren in de Agro-food of dierhouderij-sector, partijen uit de retail of handel, service providers (financiën, veevoer,...), partijen uit de energiesector en partijen die smart technology leveren voor de agrohorti-water-food sector. In Bijlage $D$ is de lijst met benaderde partijen weergegeven.

In de enquête is voor verschillende technologieën gevraagd of de partijen de genoemde technologie al gebruikten en er in investeerden, en of ze er potentie in zagen voor toekomstig gebruik, en dat ze daarmee investering in de technologie van belang vonden:

A. Welke van de volgende technologieën gebruikt of ontwikkelt uw branche / organisatie / bedrijf?

B. In welke van de volgende technologieën of
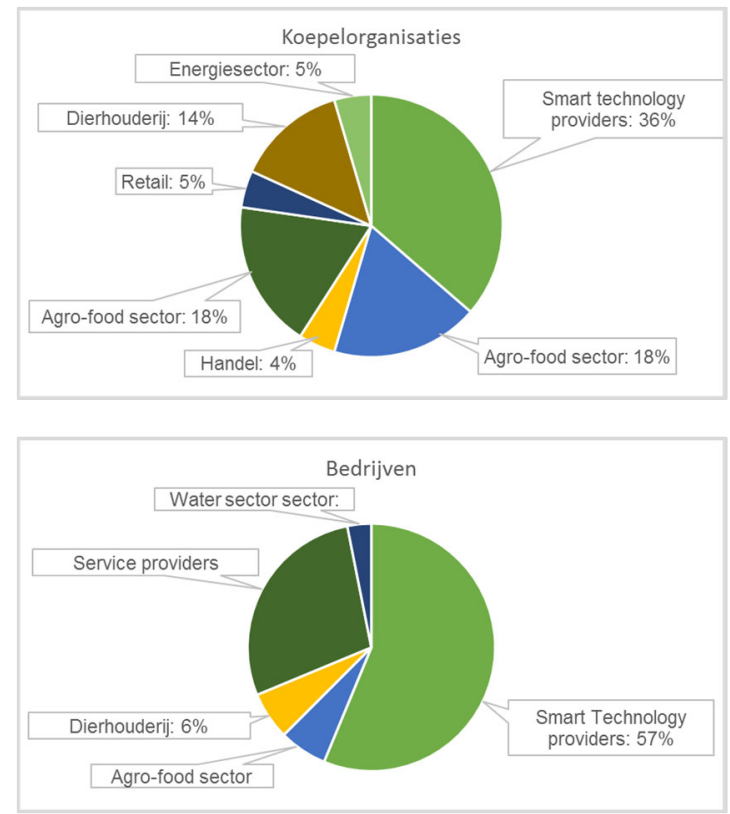

Figuur 14: Taartdiagram met partijen die uitgenodigd zijn deel te nemen aan de enquête. toepassingen bent $u$ geïnteresseerd en wilt $u$ dit realiseren in pre-competitief onderzoek met derden (Publiek-Private-Samenwerking)?

De respons op de enquête was $25 \%$, dat wil zeggen dat er 15 ingevulde enquêtes zijn geretourneerd (1x dierhouderij, 1x agro-food sector, 1x water sector, 1x service provider, 11x smart technology providers). Daarnaast waren er twee partijen die aangaven geen respons te kunnen geven voor de gestelde deadline (1x agro-food sector, 1x tech sector). Daarmee is de respons enigszins scheef verdeeld over de sectoren en dient de uitkomst als richtlijn te worden gezien.

De resultaten uit de enquête zijn weergegeven in Tabel 2 en Tabel 3. In deze tabellen is de respons op de technologie-toepassing weergegeven. Voor elk toepassingsgebied is gevraagd of de partijen nu al actief zijn met 'smart technology' op de genoemde technologie-toepassing en of men dat in de toekomst van plan is te doen.

De meeste partijen die gereageerd hebben op de enquête werken op dit moment al met precision farming en trusted food supply chains (zie Tabel 2). Ook internet of things in Agro-Horti-Water-Food scoort hoog. Het geschetste beeld is mogelijk niet representatief voor bedrijven die minder actief zijn op dit gebied.

Wat opvalt in Tabel 3 is dat vrijwel alle genoemde smart technologies bovengemiddeld scoren. Dat wil zeggen dat meer dan de helft van de respondenten de genoemde technologie nu gebruikt en mogelijkheden ziet voor meer ontwikkeling en onderzoek op het genoemde gebied en daar ook in zegt te willen investeren. Dit toont aan dat de partijen de meerwaarde van smart technology zien en verwachten dat deze nog hoger wordt. Dit past bij het agile karakter van smart technology: als een onderzoek resulteert in een innovatie, dan is de innovatie vaak het begin van grotere innovaties in het verlengde. Zo ontstaan een onderzoek - ontwikkeling - implementatie-cyclus, waarin partijen steeds verdere smart technology ontwikkelingen implementeren in hun dagelijkse bedrijfsvoering.

Op de onderwerpen Precision Farming en Decision Support / simulaties / scenario-studies / monitoring \& control zeggen alle respondenten dat ze daarin geïnteresseerd zijn en dit willen realiseren in precompetitief onderzoek met derden. 
Tabel 2: Overzicht van ranking van technologie-toepassingsgebieden vanuit de uitgezette enquête. N.B. Monitoring biodiversiteit en Food waste prevention \& reduction zijn niet aan de partijen voorgelegd, vandaar dat daar geen score voor bekend is.

\begin{tabular}{|c|c|c|}
\hline & \multirow{2}{*}{ Gebruik } & \multirow{2}{*}{ Onderzoek } \\
\hline & & \\
\hline Adaptive horticulture & * & ** \\
\hline Advanced agro-horti-water-food chains & ** & *** \\
\hline Biodiversiteit monitoring & NA & NA \\
\hline Fenotypering & ** & *** \\
\hline Food waste prevention \& reduction & NA & NA \\
\hline Internet of Things in Agro-Horti-Water-Food & *** & *** \\
\hline Last mile / e-commerce & ** & ** \\
\hline Personalised nutrition \& lifestyle & ** & ** \\
\hline Precision farming / smart farming & $* * * *$ & $\star * * * *$ \\
\hline Smart water systems / water-land-energy-food nexus & * & ** \\
\hline Trusted food supply chains & $* * * *$ & $* * * *$ \\
\hline
\end{tabular}

Tabel 3: Overzicht van ranking van smart technologies vanuit de uitgezette enquête.

\begin{tabular}{|c|c|c|}
\hline & Gebruik & Onderzoek \\
\hline Artificial intelligence / machine learning & *** & $* * * *$ \\
\hline (Autonome) robots & *** & *** \\
\hline Dataficatie / Big Data / Modelleren / Digital twins & $* * *$ & $* * * *$ \\
\hline Datamodellering en standaarden & $* * * *$ & $* * * *$ \\
\hline Decision support / simulaties / scenario-studies / monitoring \& control & $* * * *$ & $\star * * * *$ \\
\hline Mens-computer interactie & ** & ** \\
\hline Non-destructieve kwaliteitsmetingen & $* * * *$ & $* * * *$ \\
\hline Sensoren & *** & *** \\
\hline Societal concerns of Smart Technology & $* \star * *$ & $* * * *$ \\
\hline
\end{tabular}




\section{Programmeringsadvies}

In hoofdstuk 2 hebben we gezien dat de ambities geformuleerd in de LWV-missies en ook in de SDG's groot zijn. En dat de potentiële toepassingen, reikwijdte en impact van 'smart technologies' in het AgroHorti-Water-Food domein ten behoeve van deze ambities omvangrijk zijn.

Dat zorgt ervoor dat er op veel onderwerpen aanknopingspunten zitten om vanuit de 'smart technologies' bij te dragen aan de ambitieuze missies. De interesse vanuit het bedrijfsleven (hoofdstuk 5 ) is groot om nieuwe ontwikkelingen op het gebied van 'smart technology' in Agro-Horti-Water-Food te omarmen en te incorporeren in de bedrijfsvoering.

\subsection{Afbakening}

Smart technology in Agro-Horti-Water-Food is een onderwerp dat op drie niveaus speelt: enerzijds zijn er onderwerpen die één op één aan een of meer missie gekoppeld zijn (het blauwe blok in Figuur 15), anderzijds zijn er missie-doorsnijdende 'smart technology' onderwerpen die in alle missies een belangrijke rol kunnen spelen en waar ontwikkeling voornamelijk zit op TRL-niveaus $3 \mathrm{t} / \mathrm{m}$ 6, zoals bijv. robots, artificial intelligence en digital twins (het groene blok in Figuur 15). Tot slot zijn er ook op lager TRL niveau, voornamelijk $1 \mathrm{t} / \mathrm{m} 3$, op dezelfde 'smart technology' onderwerpen ontwikkelingen nodig. We adviseren deze laatste onderwerpen in de KIA Sleuteltechnologieën onder te brengen. Ze vallen buiten de scope van dit programmeringsadvies (gele blok in Figuur 15).

Dit advies behandelt ten eerste de missie-doorsnijdende 'smart technology' onderwerpen uit het groene blok (paragraaf 6.2) en sluit af met de missie-gedreven 'smart technology' onderwerpen uit het blauwe blok (paragraaf 6.3).

\subsection{Missie-doorsnijdende 'Smart Technology' in Agro-Horti- Water-Food}

Het is voor het voeden van de innovatiecyclus op het gebied van 'Smart Technology in AgroHorti-Water-Food' essentieel dat er op het vlak van smart technologie in de cross-over met het toepassingsdomein zélf vernieuwingen plaats vinden. Daarom is het eerste advies vanuit deze programmeringsstudie om missie-doorsnijdend onderzoek op de cross-over tussen 'Smart Technology' en de 'Agro-Horti-Water-Food-sector' te programmeren.

We zijn van mening dat door te investeren in de volgende twee technologische onderwerpen er op een tijdschaal van 1 tot 5 jaar forse sprongen voorwaarts kunnen worden geboekt met toepassingsmogelijkheden in alle missies. Het eerste missie-doorsnijdende onderwerp komt voor uit de constatering dat ontwikkelingen op het gebied van sensoren, computer vision technologie, machine learning en AI het mogelijk maken om steeds preciezer te kunnen meten en ingrijpen. Dit is gewenst vanuit het oogpunt van duurzaamheid: preciezer de benodigde inputs bepalen, minder voedselverspilling, minder energieverbruik, en vanuit het oogpunt van optimale benutting van de voedselproductie resp. individuele behandeling van dieren in de dierhouderij (dierenwelzijn). Het tweede missie-doorsnijdende onderwerp, geavanceerde robots en dedicated mens-machine-interactie voor optimale beslissingen, volgt uit de vertaling van de technologische trendanalyses uit paragraaf 4.3 naar het Agro-Horti-Water-Food domein.

\subsubsection{Smart Technology op meer gedetailleerde schaal}

Het eerste onderwerp waarover deze programmeringsstudie adviseert gaat over het benutten van de uitbreiding van de rekenkracht, dataverwerkingscapaciteit en veelheid aan meetmethoden om een schaalverkleiningstap te kunnen maken.

We adviseren te investeren in Smart Technology voor meten, beslissen en handelen op meer gedetailleerde schaal: van veld naar plot ("pixel farming"), van kas naar plant, van groep naar dier, van batch naar product, van watervoorziening naar leidingsegment, van 


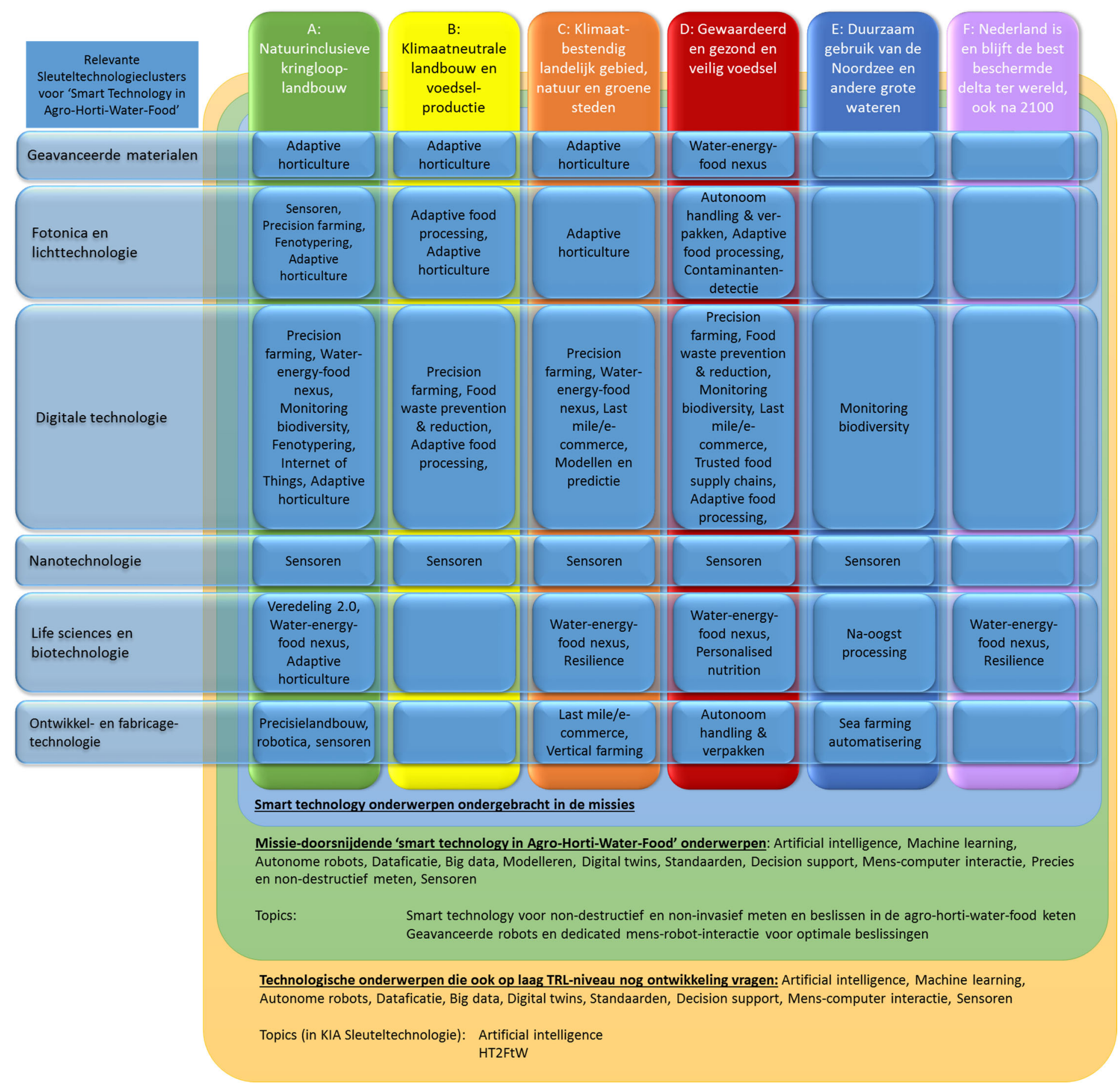

Figuur 15: de drie niveaus van Smart Technology in Agro-Horti-Water-Food: (i) onderwerpen ondergebracht in de missies, (ii) missie-doorsnijdende onderwerpen ondergebracht in dit MMIP, (iii) smart technology in Agro-Horti-Water-Food op laag TRL niveau, ondergebracht in de KIA Sleuteltechnologie. NB: van de 8 sleuteltechnologieclusters zijn chemie en quantumtechnologie weggelaten omdat zij geen raakvlak hebben met Smart Technology zoals in deze studie gedefinieerd. De indeling op TRL-niveau wordt schijnbaar gepresenteerd als zwart-wit-indeling. In de werkelijkheid is hier een glijdende schaal van toepassing en zullen onderwerpen op verschillende plekken geprogrammeerd kunnen worden. 
bevolkingsgroep naar individu. De essentie van dit deelprogramma is dat er nieuwe kennis nodig is om op het niveau van de individuele plant, dier, mens, product en/of het individuele onderdeel van een watersysteem te kunnen meten, beslissingen te kunnen nemen en deze beslissingen te kunnen uitvoeren. Het spreekt voor zich dat de beweging naar meer gedetailleerdere schaal tot op een zinnig niveau moet worden doorgevoerd, en per situatie kan verschillen.

Onderzoeksactiviteiten die nodig zijn voor de ontwikkeling op dit vlak zijn:

\begin{tabular}{|c|c|}
\hline Sensoren & $\begin{array}{l}\text { Ontwikkeling en toepassing van sensoren en sensorsystemen die on-site, high speed, } \\
\text { nauwkeurig en autonoom metingen kunnen doen, ook in praktijkomstandigheden die } \\
\text { technologisch uitdagend zijn (nat, koud/heet, vies, ...) en die het proces minimaal } \\
\text { verstoren. }\end{array}$ \\
\hline $\begin{array}{l}\text { Non-destructieve } \\
\text { metingen }\end{array}$ & $\begin{array}{l}\text { Onderzoeken welke (combinatie van) niet-destructieve en niet-invasieve } \\
\text { meettechnologieën (NIR/VIS, XRT, THz, MRI, 2D/3D, volatiles, ...) een specifieke } \\
\text { product/plant/dier/mens/systeemonderdeel-eigenschap real-time kan meten; } \\
\text { ontwikkelen van onderbouwde modellen om de gemeten data te koppelen aan } \\
\text { product/plant/dier/mens/systeemonderdeel-eigenschappen; ontwikkeling van } \\
\text { meetsystemen waarin de sensoren en algoritmes geïmplementeerd kunnen worden } \\
\text { voor proofs of principle. }\end{array}$ \\
\hline $\begin{array}{l}\text { Decision support } \\
\text { systemen }\end{array}$ & $\begin{array}{l}\text { Combineren van de beschikbare data in de keten van primaire sector tot retail om tot } \\
\text { optimale besluiten te komen van producenten en consumenten. Systemen } \\
\text { ontwikkelen voor data- en kennisgebaseerde beslissingsondersteuning met als } \\
\text { speerpunt: hoe kun je data vroeg in de keten (veredeling, teelt, houderij) en later in } \\
\text { de keten gebruiken voor voorspellingen en beslissingen? }\end{array}$ \\
\hline $\begin{array}{l}\text { Autonome robots } \\
\text { voor handelingen in } \\
\text { het primaire proces }\end{array}$ & $\begin{array}{l}\text { Ontwikkeling van autonoom opererende en lerende robots voor automatische } \\
\text { handelingen in open teelten, kassen, dierhouderijsystemen en in de verwerkende } \\
\text { industrie. Uitdaging ligt in het juist herkennen en interpreteren van situaties en } \\
\text { producten, het voldoende snel en nauwkeurig werken, het voeden van het } \\
\text { beslissingsondersteunende systeem met nieuwe data. }\end{array}$ \\
\hline $\begin{array}{l}\text { Autonome robots } \\
\text { voor diagnostiek }\end{array}$ & $\begin{array}{l}\text { Ontwikkeling van manieren om expertkennis met AI te integreren voor het monitoren } \\
\text { van plant, dier, mens, watersysteem, geoogst product of verwerkingsproces: wanneer } \\
\text { gaat het goed, wanneer moet er worden ingegrepen. Dit vraagt om context-specifieke } \\
\text { interpretatie van beschikbare data. }\end{array}$ \\
\hline Digital twins & $\begin{array}{l}\text { Ontwikkelen van model om plant, dier, watersysteem, geoogst product, of } \\
\text { verwerkingsproces digitaal te modelleren om effecten van handelingen (bijv. op het } \\
\text { gebied van smart farming of smart factory) te simuleren en zo snel en efficiënt het } \\
\text { effect van beslissingen te kunnen doorrekenen. }\end{array}$ \\
\hline
\end{tabular}

Door in te zetten op deze innovatieopgave, wordt het mogelijk om preciezer te meten, beslissen en handelen. Hierdoor wordt er impact gecreëerd voor alle missies. Voorbeelden van potentiële impact liggen op het reduceren van voedselverspilling door een betere inschatting van productkwaliteit (missie A), het verduurzamen van de veehouderij door betere metingen aan het individuele dier (missie B), het beter inrichten van de water-land-energie-food nexus door actuele metingen aan waterkwaliteit (missie C), het verstrekken van transparante informatie aan consumenten over het gekochte product (missie D), en het correct uitvoeren van vangstanalyse aan boord van vissersschepen (missie E).

\subsubsection{Geavanceerde robots en dedicated mens-machine-interactie voor optimale beslissingen}

Het tweede onderwerp waarover deze programmeringsstudie adviseert gaat over het integreren van menselijke en kunstmatige intelligentie om zo de sterke punten van mensen (creativiteit, flexibiliteit, context-awareness) en machines (logisch redeneren, 24/7 online, mogelijkheid om veel data te behappen) te combineren. Hierbij wordt optimaal gebruik gemaakt van de verwevenheid van het internet of things met het dagelijkse leven en de ontwikkelingen op AI en robotica gebied. 


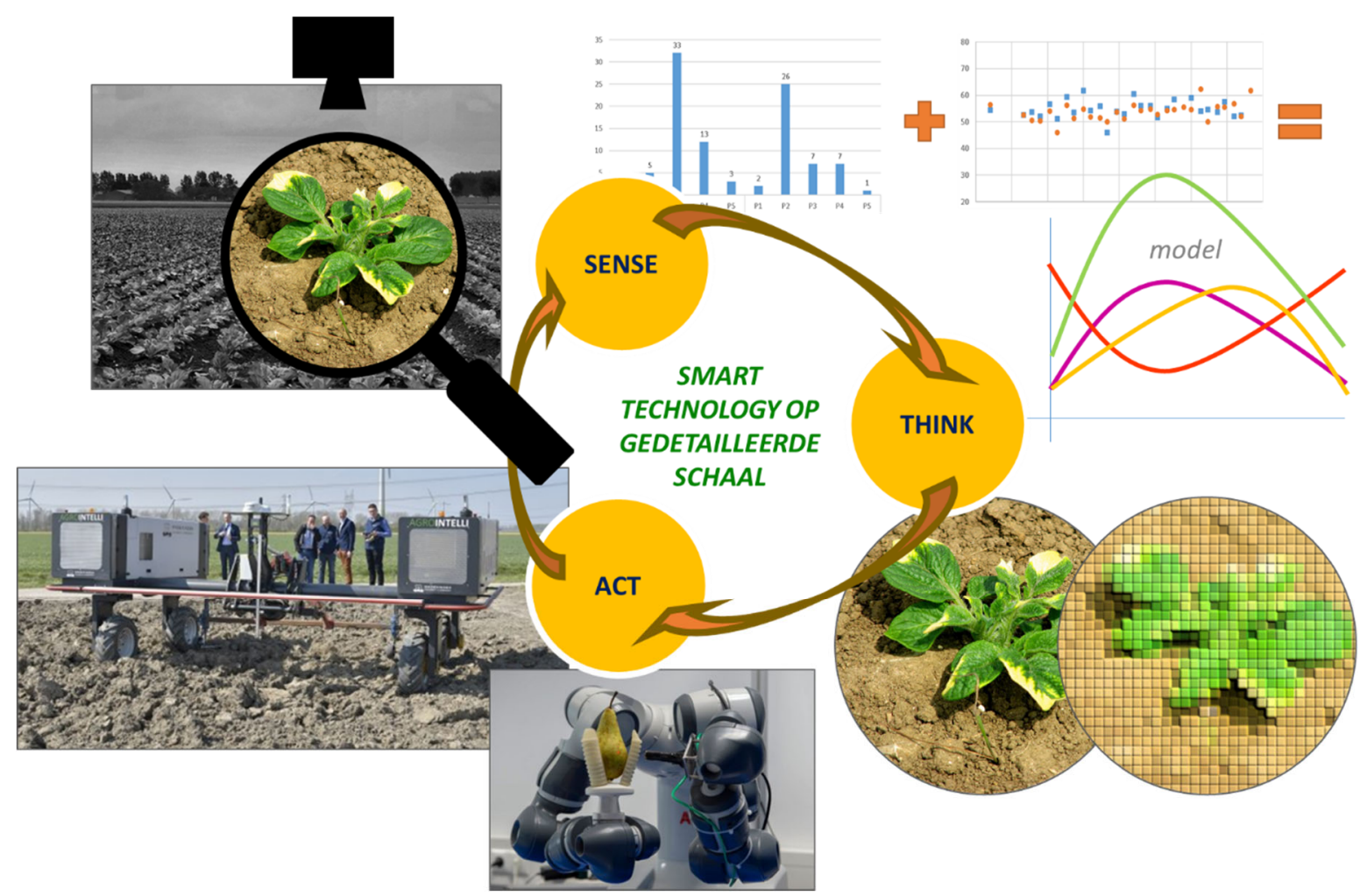

Figuur 16: Schetsmatige impressie van het onderwerp smart technology op gedetailleerde schaal. De sense-think-act cyclus wordt doorlopen voor individuele plots, planten, producten, mensen, dieren of systeemcomponenten. Sensoren nemen real-time en on-site waar, data worden geïnterpreteerd en autonome robots beslissen op basis van deze interpretaties. Digital twins spelen een rol in het creëren van de benodigde modellen.

We adviseren te investeren in geavanceerde robots en dedicated mens-machine-interactie voor optimale beslissingen in het agro-horti-water-food domein. De essentie van dit onderwerp is dat veel taken die voor mensen eenvoudig zijn voor AI-systemen complex zijn, omdat zij taakbegrip en context-awareness missen. Door mensen en machines op een goed doordachte manier samen te laten werken kunnen machines versneld leren en semiautonoom opereren, kunnen beide intelligenties hun sterktes benutten en worden daardoor betere beslissingen op basis van alle beschikbare data mogelijk. De komende vijf jaar zal de afstand tussen AI-systemen en de mens verkleind worden door middel van onderzoek op onderstaande onderwerpen. De hybride vormen van AI die zo ontstaan leveren al op korte en middelbare termijn voordeel op voor het LWV-domein.

Onderzoeksactiviteiten die nodig zijn voor de ontwikkeling op dit vlak zijn:

\begin{tabular}{|l|l|}
\hline Sensoren & $\begin{array}{l}\text { Ontwikkeling en toepassing van sensorsystemen die optimaal gebruik maken van } \\
\text { augmented en virtual reality; internet of things en wearables; auditieve en visuele } \\
\text { interfaces. }\end{array}$ \\
\hline $\begin{array}{l}\text { Decision support } \\
\text { systemen }\end{array}$ & $\begin{array}{l}\text { Ontwikkeling van modulaire beslissingsondersteunende systemen die op basis van } \\
\text { combinaties van veel data nieuwe inzichten genereren. Expert kennis, machine } \\
\text { learning, logische modellen en statistiek worden daar waar zinnig ingezet. } \\
\text { Zwaartepunt ligt op het verkrijgen van een integraal beeld van de situatie, real-time } \\
\text { monitoring, beslissingsondersteuning en early warning. }\end{array}$ \\
\hline $\begin{array}{l}\text { Dataficatie / Big } \\
\text { Data }\end{array}$ & $\begin{array}{l}\text { (Geautomatiseerd) meten, verzamelen en koppelen van meer en meer gedetailleerde } \\
\text { data over producten, grondstoffen, processen en context en die benutten om } \\
\text { geavanceerdere modellen te maken en te voeden die nauwkeurig en robuust zijn t.a.v. } \\
\text { onzekere inputdata. Aandacht voor datakwaliteit en standaardisatie. }\end{array}$ \\
\hline
\end{tabular}




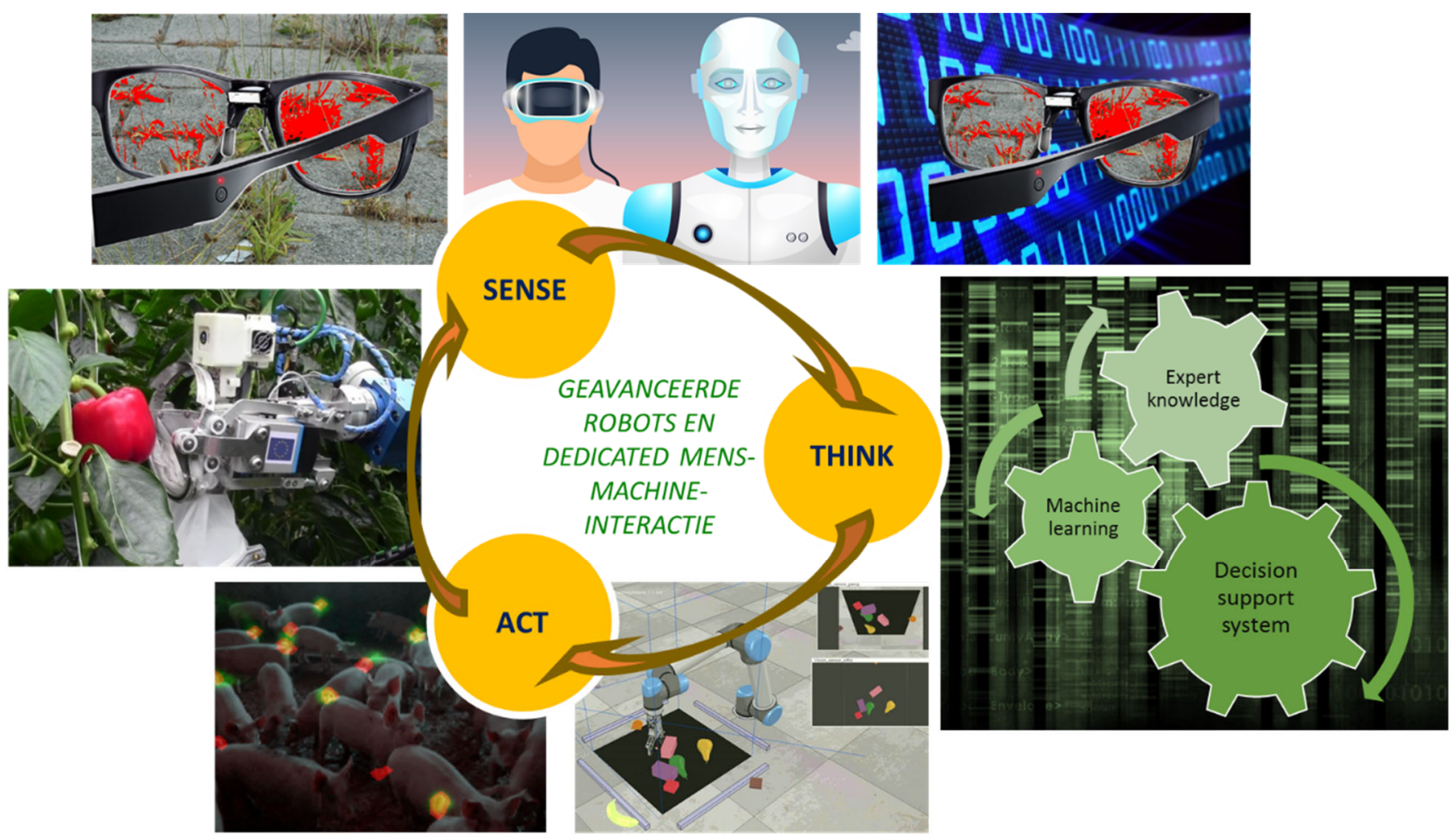

Figuur 17: Schetsmatige impressie van het onderwerp geavanceerde robots en dedicated mens-machine interactie. De sense-think-act cyclus wordt doorlopen door context-bewuste waarnemingen te doen, (big) data te processen, lerende systemen te bouwen en te werken aan hybride AI-systemen door mens-machine-omgeving interactie. Augmented reality, semantisch-verrijkte modellen, robots die leren van mensen en vervolgens autonoom kunnen opereren. In essentie gaat het over het maken van optimale beslissingen door intelligente actoren, zowel mens als AI-systeem. (Bron: foto's uit beeldbank WUR en ontwerp van macrovector / Freepik)

\begin{tabular}{|l|l|}
\hline $\begin{array}{l}\text { Artificial } \\
\text { intelligence }\end{array}$ & $\begin{array}{l}\text { Investeren in de volgende generatie AI voor betere beslissingen in de Agro-Horti- } \\
\text { Water-Food sector: semantisch-verrijkte AI (combinatie van expertkennis met } \\
\text { machine learning), explainable AI (waarom maakt het AI systeem de beslissing), } \\
\text { hybride AI (reinfocement learning, learning by imitation), en ethical AI (is de } \\
\text { toepassing van het AI systeem in deze context wenselijk, onder welke } \\
\text { omstandigheden kan het wel/niet (denk bijv. aan dierenwelzijn in animal-computer } \\
\text { interacties)). Robots opereren autonoom of semiautonoom in praktijksituaties en } \\
\text { maken gebruik van de optimale redeneer- en besliskracht die vanuit deze hybride } \\
\text { vormen van AI beschikbaar is. }\end{array}$ \\
\hline Mens-computer- \\
omgeving interactie \\
$\begin{array}{l}\text { Ontwikkeling van 'smart spaces': systemen waarin mens en machine gezamenlijk } \\
\text { observeren, beslissen en handelen met speciale aandacht voor samenwerking met } \\
\text { vele actoren, optimale taakverdeling, integrale afweging voor het bereiken van } \\
\text { optimale beslissingen in steeds wisselende contexten. Hieronder valt zowel } \\
\text { systeemontwerp als ontwikkeling van de bouwstenen voor de 'smart spaces'. } \\
\text { Aandacht voor vraagstukken rond implementatie in de beroepspraktijk (bijv. user } \\
\text { interactie, robot-dier interactie, sociale aspecten, werkklimaat, arbeidsomstandig- } \\
\text { heden, organisatie, wetgeving en economische aspecten). }\end{array}$
\end{tabular}


Door in te zetten op deze innovatieopgave, wordt het mogelijk om vanuit meer gegevens intelligentere en meer betrouwbare conclusies te trekken, waardoor er impact zal zijn voor alle missies. Voorbeelden van potentiële impact liggen op het beter begrijpen van biodiversiteitsveranderingen (missie A), het autonoom aansturen van de kas (missie B), het doorrekenen en begrijpen van effecten van klimaatverandering op de primaire productie en de versketen (missie $C$ ), het maken van gepersonaliseerde gezonde en duurzame beslissingen m.b.t. voedsel (missie D), en het omgaan van energie- en watervraagstukken in geval van schaarste of overvloed (missie E).

\subsection{Missie-gedreven 'Smart Technology' in Agro-Horti-Water- Food}

De belangrijkste missie-gedreven 'Smart Technology' onderwerpen die rechtstreeks uit de maatschappelijke opgave komen zijn weergegeven in Tabel 1 (pagina 19). Op elk van deze onderwerpen vindt al onderzoek plaats, en op elk van deze onderwerpen zijn grote stappen voorwaarts mogelijk. In hoofdstuk 4.2 zijn de kennis- en innovatieopgaven op deze onderwerpen weergegeven.

Het advies vanuit deze programmeringsstudie is om het onderzoek op 'smart technology'-gebied op deze onderwerpen verder te brengen door de kennis- en innovatieopgaven te programmeren vanuit de MMIPs die rechtstreeks aan de missies gerelateerd zijn. Daarnaast is het ook noodzakelijk om te investeren in implementatie van innovaties in de praktijk. Dit zal deels vanuit de topsectoren kunnen, maar ook deels via andere instrumenten zoals regionale investeringen of de milieu-investeringsaftrek (MIA).

\subsection{Conclusie}

De impact van Smart Technology in Agro-Horti-Water-Food context is enorm. Ontwikkelingen gaan razendsnel en systeemveranderingen als gevolg van 'smart technologies' zijn groot. Wereldwijd vindt er veel onderzoek plaats, zowel op het gebied van Smart Technology als op het gebied van Agro-HortiWater-Food. Behalve Wageningen UR vindt er bijvoorbeeld bij INRA, RISE en Agro ParisTech in Europa onderzoek plaats op de cross-over van Smart Technology en Agro-Horti-Water-Food. Ook buiten Europa, in bijv. Japan, Verenigde Staten, India en Singapore gaan de ontwikkelingen snel. Het is interessant om vanuit de programmering van de topsectoren samenwerkings- en kennisuitwisselingsmogelijkheden te inventariseren.

We zijn van mening dat de twee genoemde onderwerpen in paragraaf 6.2, nl. kleinschalig meten en geavanceerde robots met hybride AI, belangrijke stappen voorwaarts mogelijk maken voor de ambitieuze doelen die het ministerie zich gesteld heeft, nu en in de toekomst. We adviseren dan ook om missie-doorsnijdend onderzoek op 'smart technology'-gebied voor de Agro-Horti-Water-Food sector te programmeren op de twee genoemde onderwerpen vanuit een aparte MMIP binnen de KIA LWV.

Daarnaast is het essentieel om ook het direct toepasbare onderzoek op de verschillende missiegerelateerde onderwerpen te (blijven) financieren, zodat ook op deze onderwerpen technologische voortgang plaatsvindt. De innovatie-opgaven hiervoor zijn in paragraaf 4.2 uitgewerkt. Dat helpt om de concurrentiepositie van Nederland te behouden en te werken aan de maatschappelijke opgaven.

Vervolgens is het onze overtuiging dat 'Smart Technology in Agro-Horti-Water-Food' vraagt om continue aandacht op het gebied van data-infrastructuur: data-acquisitie, datamanagement, standaardisering, linked data, ontologie-ontwikkeling, big data analyse en kennismodellering zijn essentieel voor een effectieve toepassing van Smart Technology. Als het beheer van data niet op orde is, wordt het realiseren van de potentie van Smart Technology een stuk moeilijker en inefficiënter. Dit kan de sector zich niet veroorloven. Daarom adviseren we ook om in onderzoek, ontwikkeling en uitrol te investeren om de data-infrastructuur in het domein in goede banen te leiden. 
Tot slot zijn 'societal en economic concerns' belangrijke randvoorwaardelijke zaken voor de cross-over van 'Smart Technology' in Agro-Horti-Water-Food. De impact van robotisering en digitalisering op het welbevinden van mens en dier is een factor die belangrijk is. Juist door naar de totale implicaties te kijken van de introductie van nieuwe technologie, wordt maatschappelijke acceptatie ingebed in de ontwikkeling. Wij adviseren om bij elk projectvoorstel de societal concerns te adresseren: de invloed van robotisering op de arbeidsomstandigheden en/of het dierenwelzijn, het effect van digitalisering op veiligheid en privacy etc. dienen bij elk voorstel op dit gebied benoemd te worden en maatregelen om negatieve effecten te mitigeren horen onderdeel te zijn van de voorstellen.

Met deze randvoorwaardelijke zaken afgedekt en met voldoende aandacht voor de data-infrastructuur in de sector, bieden de twee genoemde missie-doorsnijdende onderwerpen en de missie-gerelateerde toepassingsgebieden voldoende uitdaging én potentie voor het realiseren van concrete bijdragen aan de ambitieuze doelen gesteld in de LWV-missies voor de komende vijf jaar. 


\section{Bijlage A: Overzicht sleuteltechnologieën}

In juni 2018 is een rapport verschenen getiteld "Kwantitatieve analyse van onderzoek en innovatie in sleuteltechnologieën in Nederland", opgesteld in opdracht van het Nederlandse Ministerie van Economische Zaken en Klimaat (EZK) door Elsevier Research Intelligence. In dit rapport wordt een overzicht gegeven van clusters van sleuteltechnologieën. Dit overzicht herhalen we hier omdat het een context geeft aan deze programmeringsstudie. 'Smart Technology in Agro-Horti-Water-Food' heeft betrekking op het raakvlak tussen de digitale wereld en de fysieke wereld. Daarmee omvat het de sleuteltechnologieclusters Digitale Technologie, en delen van de sleuteltechnologieclusters Fotonica \& Lichttechnologie, Ontwikkel- \& Fabricagetechnologie, Nanotechnologie, Life sciences en biotechnologie en Ontwikkel- en fabricagetechnologie.

\begin{tabular}{|c|c|}
\hline Category & Technology name \\
\hline \multirow[t]{9}{*}{ Advanced Materials } & Bio (related) materials and soft material \\
\hline & Composite and ceramics \\
\hline & Designer and meta materials \\
\hline & Energy conversion \\
\hline & Energy storage materials \\
\hline & Optical/electronic/magnetic materials (incl 2D and graphene) \\
\hline & Smart/self healing/self-organising materials \\
\hline & Structural materials \\
\hline & Thin films and coatings \\
\hline \multirow[t]{6}{*}{ Chemical technologies } & (Bio)Process technology including process intensification \\
\hline & Analytic technologies \\
\hline & Catalysis \\
\hline & Electrification / Hydrogen technology / power to gas \\
\hline & Microreactors \\
\hline & Separation technology \\
\hline \multirow{6}{*}{ Digital technologies } & Artificial intelligence (incl. machine and deep learning) \\
\hline & Big data and data analytics \\
\hline & Block chain \\
\hline & Encryption technologies/ digital security \\
\hline & High Performance Computing Grid Computing and Cloud \\
\hline & Technologies/Computing \\
\hline \multirow{7}{*}{$\begin{array}{l}\text { Engineering and } \\
\text { fabrication technologies }\end{array}$} & (Opto)mechatronics \\
\hline & Additive manufacturing/3D printing \\
\hline & Cyberphysical systems \\
\hline & High frequency and mixed signal technologies \\
\hline & Imaging technologies \\
\hline & Robotics \\
\hline & Sensors and actuators \\
\hline \multirow[t]{9}{*}{ Life sciences technologies } & Biocatalysis \\
\hline & Biochips and biosensors \\
\hline & Biofabrication \\
\hline & Gene editing/precise genetic engineering \\
\hline & $\begin{array}{l}\text { Genomics/proteomics/metabolomics/glycomics/X-omics } \\
\text { Industrial biotechnology (white) }\end{array}$ \\
\hline & Nanomedicine \\
\hline & Organ on a chip \\
\hline & Stem cell technology \\
\hline & Synthetic cell technology \\
\hline \multirow[t]{6}{*}{ Nanotechnologies } & Bionanotechnology \\
\hline & Micro and nanofluidics \\
\hline & Nanomanufacturing \\
\hline & Nanomaterials \\
\hline & Nanoscale devices \\
\hline & Semiconductor devices \\
\hline \multirow[t]{4}{*}{$\begin{array}{l}\text { Photonics and light } \\
\text { technologies }\end{array}$} & Integrated photonics \\
\hline & Photon generation technologies \\
\hline & Photonic detection \\
\hline & Photovoltaics \\
\hline \multirow[t]{3}{*}{ Quantum technologies } & Quantum communication \\
\hline & Quantum computing \\
\hline & Quantum sensors and metrology \\
\hline
\end{tabular}

Figuur 18: categorisering van sleuteltechnologieën zoals in de Elsevier-publicatie "Kwantitatieve analyse van onderzoek en innovatie in sleuteltechnologieën in Nederland" uit juni 2018. 


\section{Bijlage B: Lopende projecten gefinancierd door de topsectoren}

\begin{tabular}{|c|c|c|c|c|c|c|c|c|c|c|c|c|c|c|c|c|c|c|c|c|}
\hline & \multicolumn{11}{|c|}{ Technologie toepassingsgebieden } & \multicolumn{9}{|c|}{ Technologieën } \\
\hline & 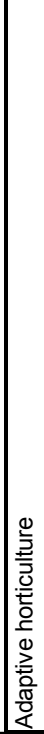 & 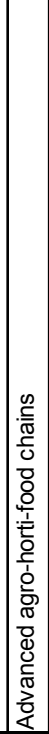 & 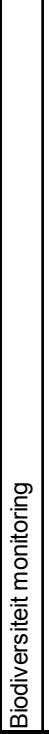 & 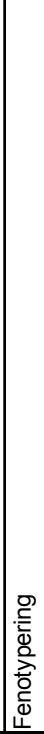 & 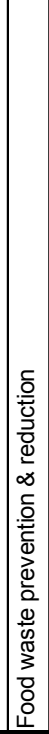 & 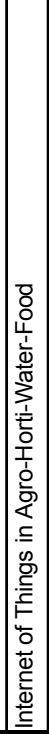 & 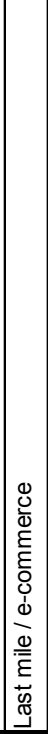 & 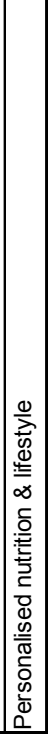 & 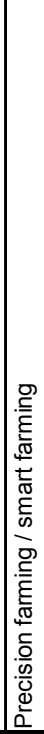 & 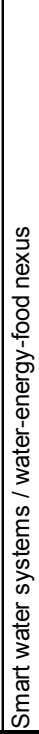 & 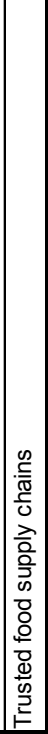 & 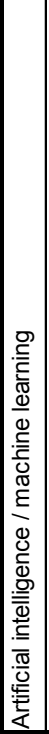 & \begin{tabular}{|l|} 
\\
\\
\\
\\
\\
0
\end{tabular} & 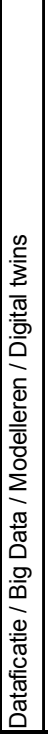 & 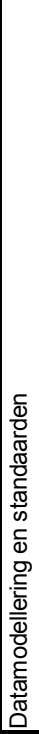 & 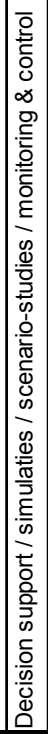 & 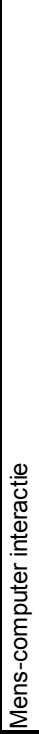 & 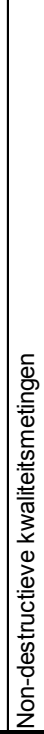 & 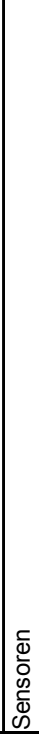 & 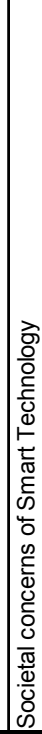 \\
\hline AF-14252 Farm Digital & & & & & & & & & & & $x$ & & & $x$ & & & & & & \\
\hline AF-14275 Op naar precisielandbouw 2.0 & & & & & & & & & $x$ & & & & & & & $x$ & & & $x$ & \\
\hline AF-15240 Interactieve bewaarsystemen voor aardappelen & & & & & & & & & & & & & & & & $x$ & & & $x$ & \\
\hline AF-15262 Personalized Nutrition and Health & & & & & & & & $x$ & & & & $x$ & & $x$ & & $x$ & & & $x$ & \\
\hline AF-16003 The Quantified Consumer & & & & & & & & $x$ & & & & & & $x$ & & & & & $\mathrm{x}$ & \\
\hline AF-16059 Big Data voor optimalisatie vleeskuikenketen & & & & & & & & & & & & & & $x$ & & $x$ & & & & \\
\hline AF-16067 Smart Tools voor Vitale Varkens & & & & & & $x$ & & & & & & & & $x$ & & $x$ & & & $x$ & \\
\hline AF-16082 Cool Data & & & & & & & & & & & $x$ & $x$ & & $x$ & & $x$ & & & & \\
\hline AF-16096 Smart Food Intake & & & & & & & & $x$ & & & & & & $x$ & & & & & & \\
\hline AF-16101 DATA-FAIR & & & & & & $x$ & & & & & $x$ & & & $x$ & $x$ & & & & & \\
\hline AF-16160 Safer Food with Big Data & & & & & & & & & & & & & & $x$ & & $x$ & & & & \\
\hline $\begin{array}{l}\text { AF-16190 Slimme Mechanisatie - Automatisering - } \\
\text { Robotisering voor Akkerbouw }\end{array}$ & & & & $x$ & & & & & & & & & $x$ & & & & & & $x$ & \\
\hline AF-16191 Data Intensive Smart Agrifood Chains & & $x$ & & & & $\mathrm{x}$ & & & & & & & $x$ & $x$ & & $x$ & & & $x$ & \\
\hline AF-16201 Trusted source & & & & & & & & & & & $x$ & & & $x$ & $x$ & & & & & $x$ \\
\hline AF-17038 Snelle on-site methoden & & & & & & & & & & & $x$ & & & & & & & & $x$ & $x$ \\
\hline AF-17215 Innovative Smart Materials and Sensors & & $x$ & & & $x$ & & & & & & & & & & & & & & $x$ & \\
\hline $\begin{array}{l}\text { AF-17221 Sensors and ICT applications for effective use of } \\
\text { fungicides }\end{array}$ & & & & & & & & & $x$ & & & & & & & & & & $x$ & \\
\hline AF-18020 GrazeGuide & & & & & & & & & & & & & & $x$ & & & & & $x$ & \\
\hline AF-18060 Transparant gezond \& duurzaam & & & & & & $x$ & $x$ & $x$ & & & & & & & & $x$ & & & & \\
\hline $\begin{array}{l}\text { AF-18083 Monitoren diepteregeling en nauwkeurigheid } \\
\text { mesttoediening }\end{array}$ & & & & & & & & & $x$ & & & & & & & & & & $x$ & \\
\hline AF-18084 Internet of Food & & & & & & $x$ & & & & & & & & $x$ & & & & & $x$ & \\
\hline AF-18086 Toekomstbestendig diertransport & & & & & & & & & & & & & & $x$ & & $x$ & & & $x$ & $x$ \\
\hline AF-18101 Precisielandbouw 4.0 & & & & & & & & & $\mathrm{x}$ & & $x$ & $x$ & & $x$ & & $x$ & & & $x$ & \\
\hline AF-18115 CuRly Pig TAIL & & & & & & & & & & & & $x$ & & $x$ & & $x$ & & & $\mathrm{x}$ & \\
\hline MIT-15003 Cloudwerker & & & & & & $x$ & & & $x$ & & & & & $x$ & & & & & $x$ & \\
\hline MIT-16001 AgTech planner voor (drone)loonwerkers & & & & & & & & & & & & & $x$ & $x$ & & & & & $x$ & \\
\hline MIT-16002 CO2-use reducing packaging robot & & $\mathrm{x}$ & & & & & & & & & & & $x$ & & & & & & & \\
\hline $\begin{array}{l}\text { MIT-16006 'TOOM' - BigData loggingsysteem voor de vrije } \\
\text { kraamzeug }\end{array}$ & & & & & & & & & & & & & & & & & & & $x$ & \\
\hline $\begin{array}{l}\text { MIT-16011 Geautomatiseerd oogsten en transporteren van } \\
\text { chrysanten }\end{array}$ & & $\mathrm{x}$ & & & & & & & & & & & & & & & & $x$ & & $x$ \\
\hline MIT-16012 ACRO & & & & $\mathrm{x}$ & & & & & $\mathrm{x}$ & & & $x$ & & & & & & & & \\
\hline PPS use cases for 3D printing & & $\mathrm{x}$ & & & & & & & & & & & & $x$ & & & & & & \\
\hline HT17222 Exploitation of high-tech plant phenotyping tools & & & & $\mathrm{x}$ & & & & & & & & & & & & & & $x$ & & \\
\hline HT17228 Data Driven Integrated Growing Systems & $x$ & & & & & & & & & & & & & $x$ & & $\mathrm{x}$ & & & & \\
\hline KV 1406-031 GreenCHAINge Groente \& Fruit & & & & & $x$ & & & & & & & & & $x$ & & $x$ & & $x$ & $x$ & \\
\hline
\end{tabular}




\begin{tabular}{|c|c|c|c|c|c|c|c|c|c|c|c|c|c|c|c|c|c|c|c|c|}
\hline & \multicolumn{11}{|c|}{ Technologie toepassingsgebieden } & \multicolumn{9}{|c|}{ Technologieën } \\
\hline & $\mid$ & 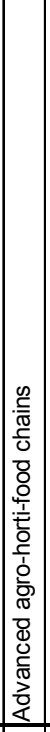 & 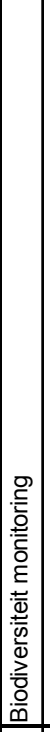 & 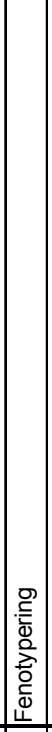 & 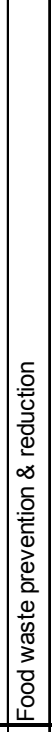 & 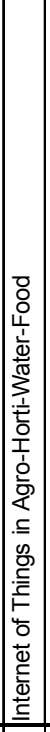 & 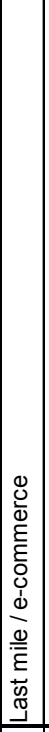 & 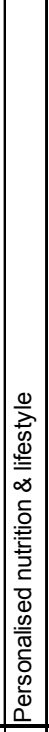 & 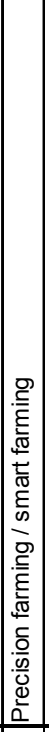 & 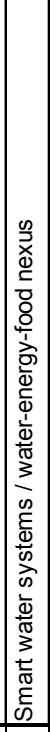 & 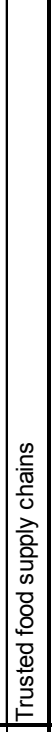 & 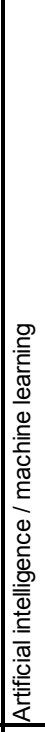 & 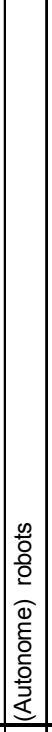 & 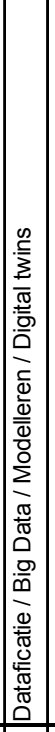 & 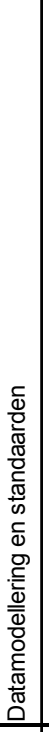 & 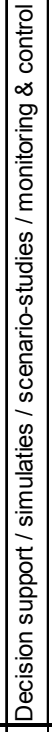 & 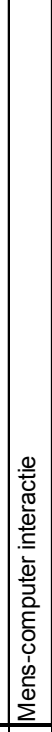 & 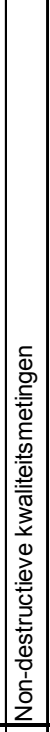 & 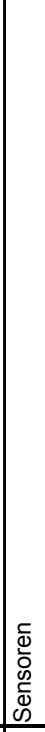 & 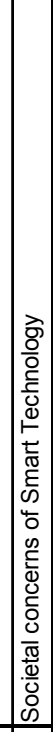 \\
\hline KV 1406-077 iFlow & $x$ & & & & & & $\mathrm{x}$ & & & & & & & $\mathrm{x}$ & & $x$ & & & & \\
\hline KV 1406-101: BIGt\&u & & & & & & $\mathrm{x}$ & & & & & $x$ & & & $x$ & & & & & $x$ & \\
\hline $\begin{array}{l}\text { KV 1406-111 Beslissingsondersteuning voor toeleveranciers } \\
\text { van kassen }\end{array}$ & & & & & & & & & & & & & & & & $x$ & & & & \\
\hline KV 1406-129 Compliance made easy & & & & & & $\mathrm{x}$ & & & & & & & & $\mathrm{x}$ & & & & & & \\
\hline KV1406-060 Mechanische aspergeoogst & & & & & & & & & & & & & $x$ & & & $x$ & & $x$ & & \\
\hline KV1605 068 Market Intelligence Voedingstuinbouw 2.0 & & & & & & & & $x$ & & & & & & & & $x$ & & & & \\
\hline KV1605 069 Global Design Basics for Greenhouse Structures & & & & & & & & & & & & & & $x$ & & & & & & \\
\hline $\begin{array}{l}\text { TU 1509-028 Vaststellen norm voor het meten van optische } \\
\text { eigenschappen van (diffuse) kasdek- en schermmaterialen }\end{array}$ & $x$ & & & & & & & & & & & & & & & $x$ & & & & \\
\hline TU 1605-043 Humistatus & & & & & $x$ & & & & & & & & & & & $x$ & & & $x$ & \\
\hline TU 18092 SIOM 2 & $x$ & & & & & & & & & & $x$ & & & $\mathrm{x}$ & & & & & & \\
\hline TU1509-087 Patterns for Profit & & & & & & & & & & & & $x$ & & & & & $x$ & $x$ & & \\
\hline TU1604-025 Precisie tuinbouw & & & & & $x$ & $x$ & & & $x$ & & & & & & & & & & $x$ & \\
\hline $\begin{array}{l}\text { TU-1605-029 Optimale Diagnostiek door gebruik innovatieve } \\
\text { detectiemethoden }\end{array}$ & & & & & & & & & & & & & & $x$ & & & & & & \\
\hline $\begin{array}{l}\text { TU1605-090 Ketenbenadering voor verlaging milieu-impact } \\
\text { sierteelt }\end{array}$ & & & & & & & & & $x$ & & $x$ & & & $x$ & & & & & & \\
\hline TU18009 Prediction of seed vigour & & & & $\mathrm{x}$ & & & & & & & & $x$ & & & & & & $x$ & $x$ & \\
\hline TU18034 Visual Analytics for Plant Pangenomes & & & & & & & & & & & & & & $x$ & & $x$ & & & & \\
\hline $\begin{array}{l}\text { TU18036 Optimalisatie bemesting met ion specifieke } \\
\text { sensoren }\end{array}$ & & & & & & & & & $x$ & & & & & & & & & & $x$ & \\
\hline TU18066 Bollenrevolutie 4.0 & $x$ & & & & & & & & & & & & & $x$ & & $x$ & & & & \\
\hline TU18084 Waterkwaliteit snel in beeld & & & & & & & & & & $x$ & & & & & & $x$ & & $x$ & $x$ & \\
\hline TU18098 Fresh on Demand & & & & & $x$ & & & $x$ & & & $x$ & $x$ & & $x$ & & $x$ & & $x$ & & \\
\hline TU18125 Blockchain & & & & & & & & & & & $x$ & & & $x$ & $x$ & & & & & \\
\hline TU18145 Augmented Reality & & & & & & $\mathrm{x}$ & & & & & & & & $x$ & & & & & $x$ & \\
\hline $\begin{array}{l}\text { Big Data Epidemiologie - statistische relatie drinkwater } \\
\text { kwaliteit tot gezondheid }\end{array}$ & & & & & & & & & & $x$ & & & & $x$ & & & & & & \\
\hline $\begin{array}{l}\text { De stedelijke watertransport infrastructuur als enabler voor } \\
\text { resource recovery }\end{array}$ & & & & & & & & & & $x$ & & & & & & $x$ & & & & \\
\hline DiAMANT-Water: Datamanagement van de Toekomst & & & & & & & & & & & & $x$ & & $x$ & $x$ & & & & & \\
\hline Freshkeeper & & & & & & & & & & & & & & & & $x$ & & & $x$ & \\
\hline $\begin{array}{l}\text { INTEREST - Investeringen in en rendementen van } \\
\text { sensornetwerken }\end{array}$ & & & & & & $x$ & & & & & & & & & & & & & $x$ & \\
\hline MIIP 002 Smart Sensor Fusion & & & & & & & & & & & & & & $x$ & & $x$ & & & & \\
\hline MIIP 004 Toepassing van zwerm algoritmen & & & & & & & & & & & & $x$ & & & & & $x$ & & & $x$ \\
\hline MIIP 005 Aquatic Drones & & & & & & & & & & & & & $x$ & & & $x$ & & & $x$ & \\
\hline $\begin{array}{l}\text { MIIP } 006 \text { Het meten van baggerpluimen met een aquatische } \\
\text { drone }\end{array}$ & & & $x$ & & & & & & & & & & $x$ & & & $x$ & & & $x$ & \\
\hline MIIP 018 Veiligheid van data & & & & & & $\mathrm{x}$ & & & & & & & & & & & & & & $\mathrm{x}$ \\
\hline MIIP 023 Haptic control for small ships & & & & & & & & & & & & $x$ & & & & & $x$ & & $x$ & \\
\hline On-site sensoring \& monitoring & & & & & & & & & & $\mathrm{x}$ & & $x$ & & & & & & & $x$ & \\
\hline
\end{tabular}




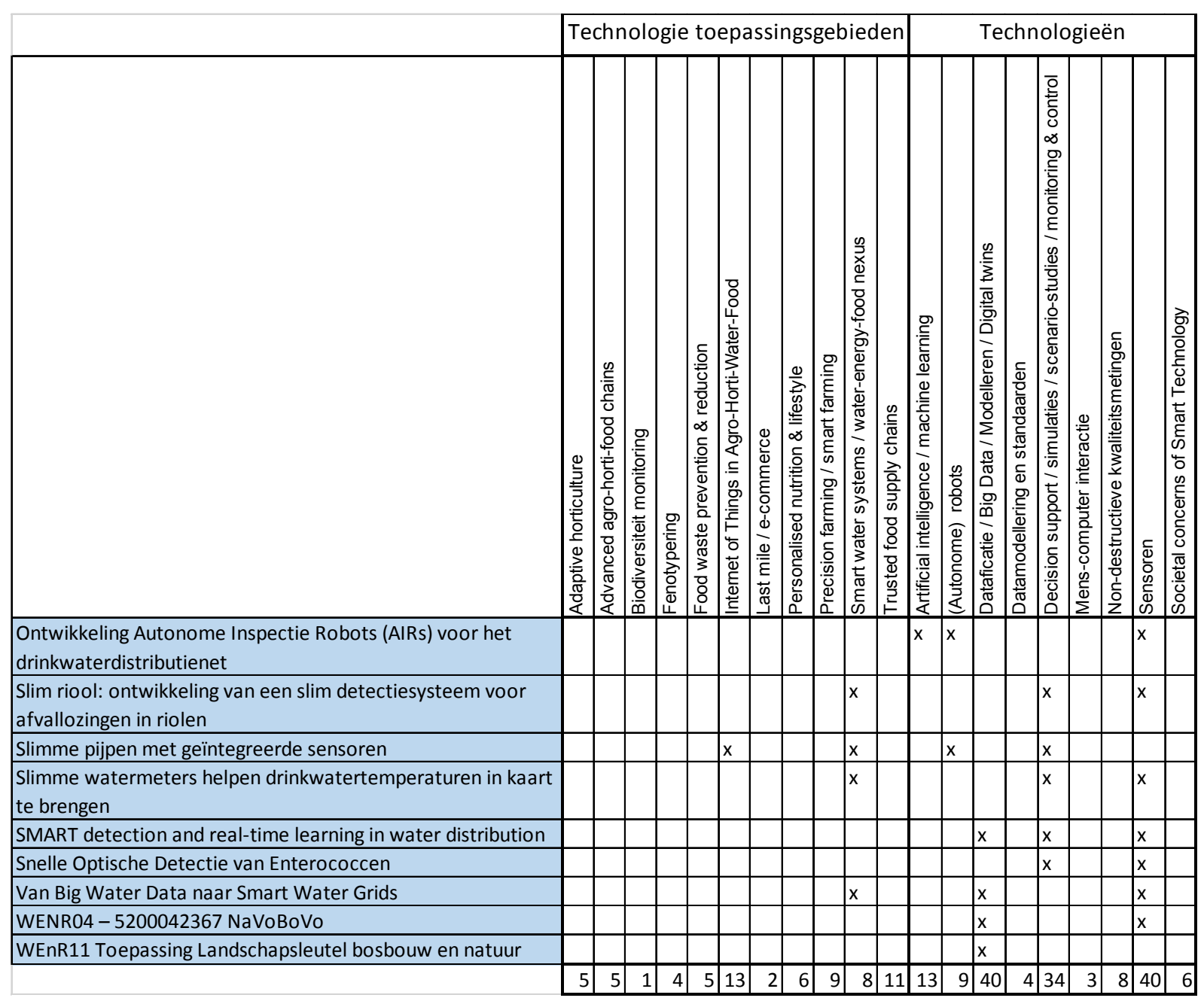




\section{Bijlage C: Lopende projecten gefinancierd door de EU}

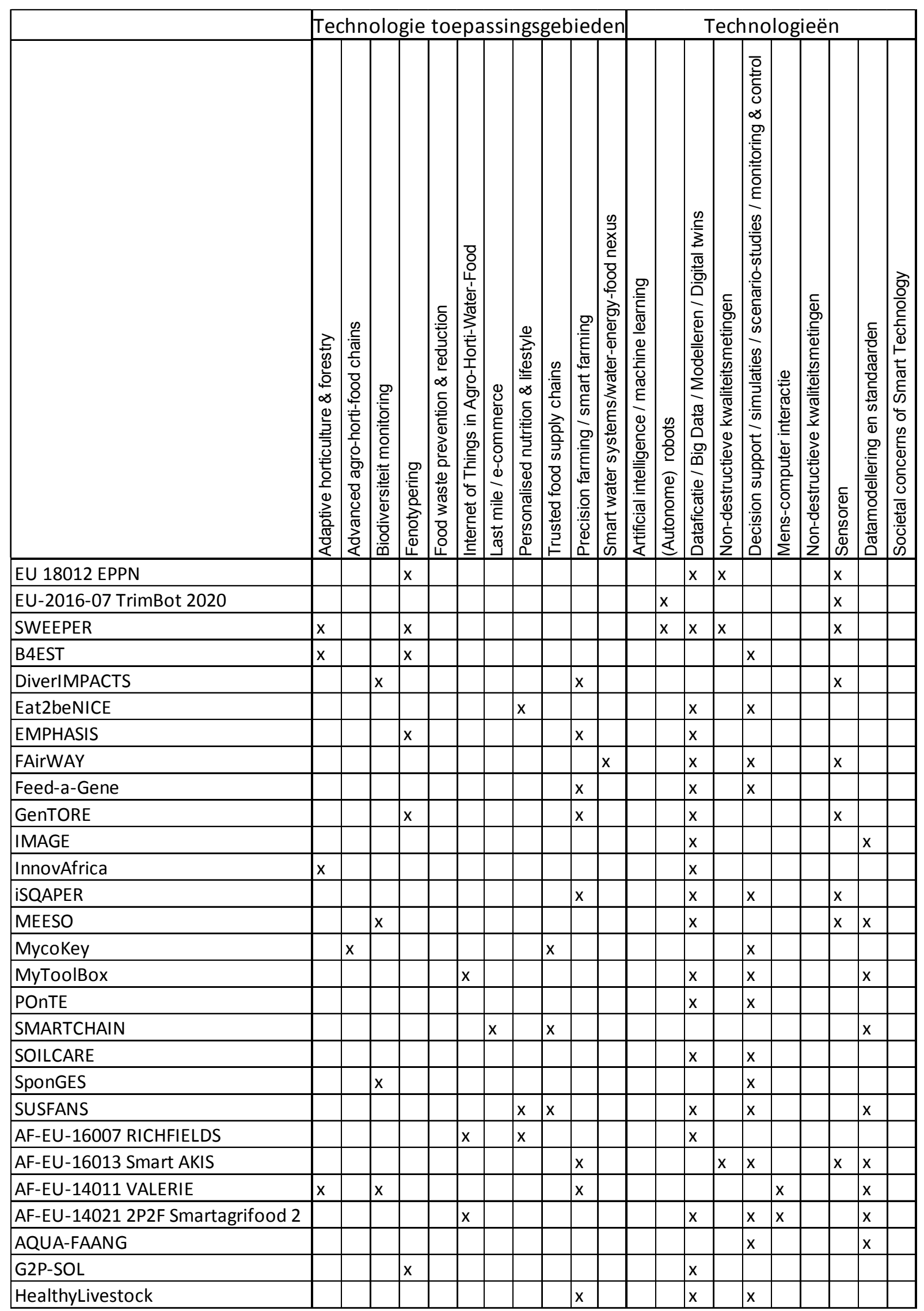




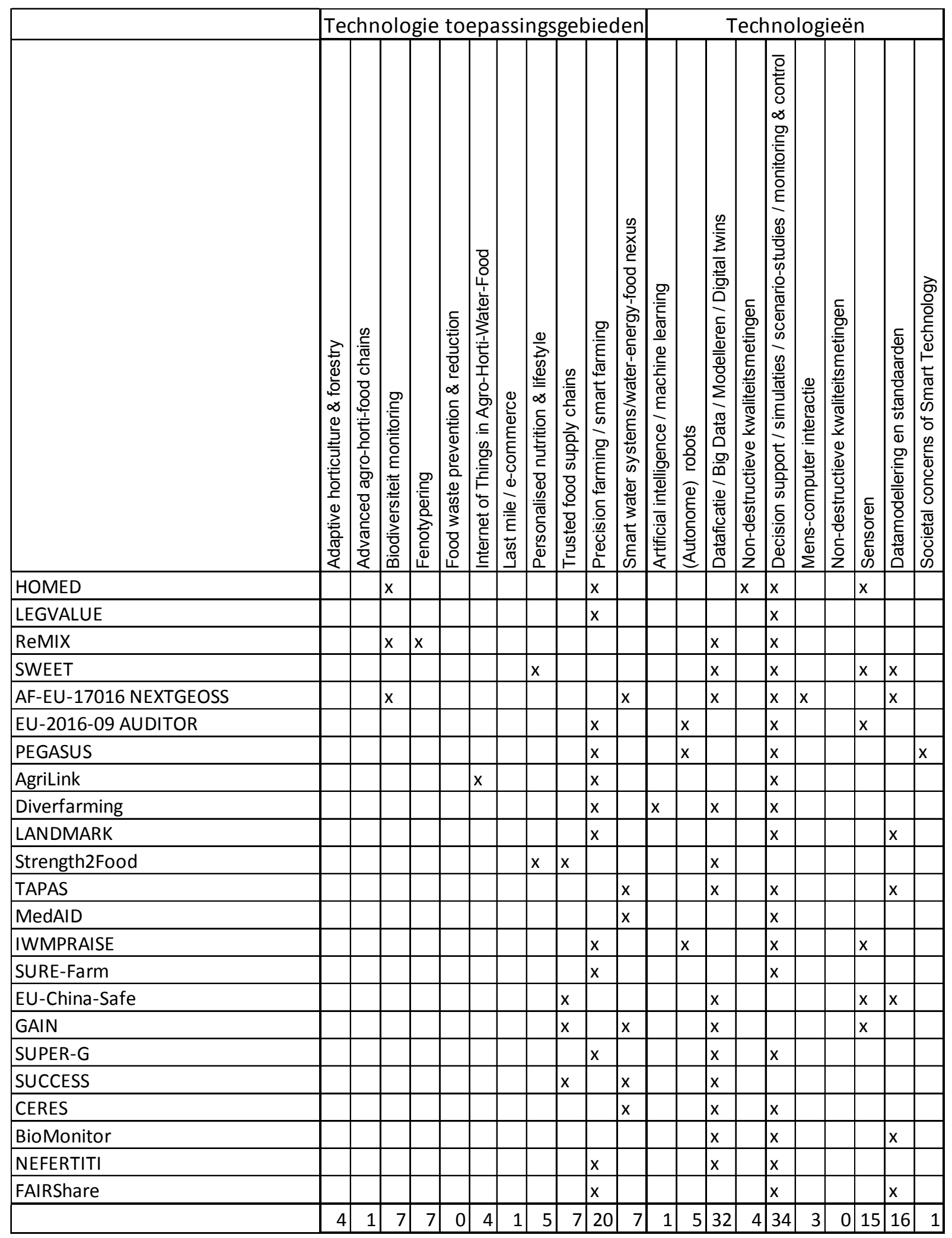




\section{Bijlage D: Deelnemerslijst enquête}

De 15 onderstaande bedrijven en koepelorganisaties hebben een ingevulde enquête geretourneerd.

- AgroConnect

- Axians

- BO-Akkerbouw

- CoNet

- FarmResult

- FoodInsights

- FME

- $\mathrm{GS1}$

- i3B

- Lely

- NEO

- Siemens Digital Factory

- VAA

- Vitens

- VKON 




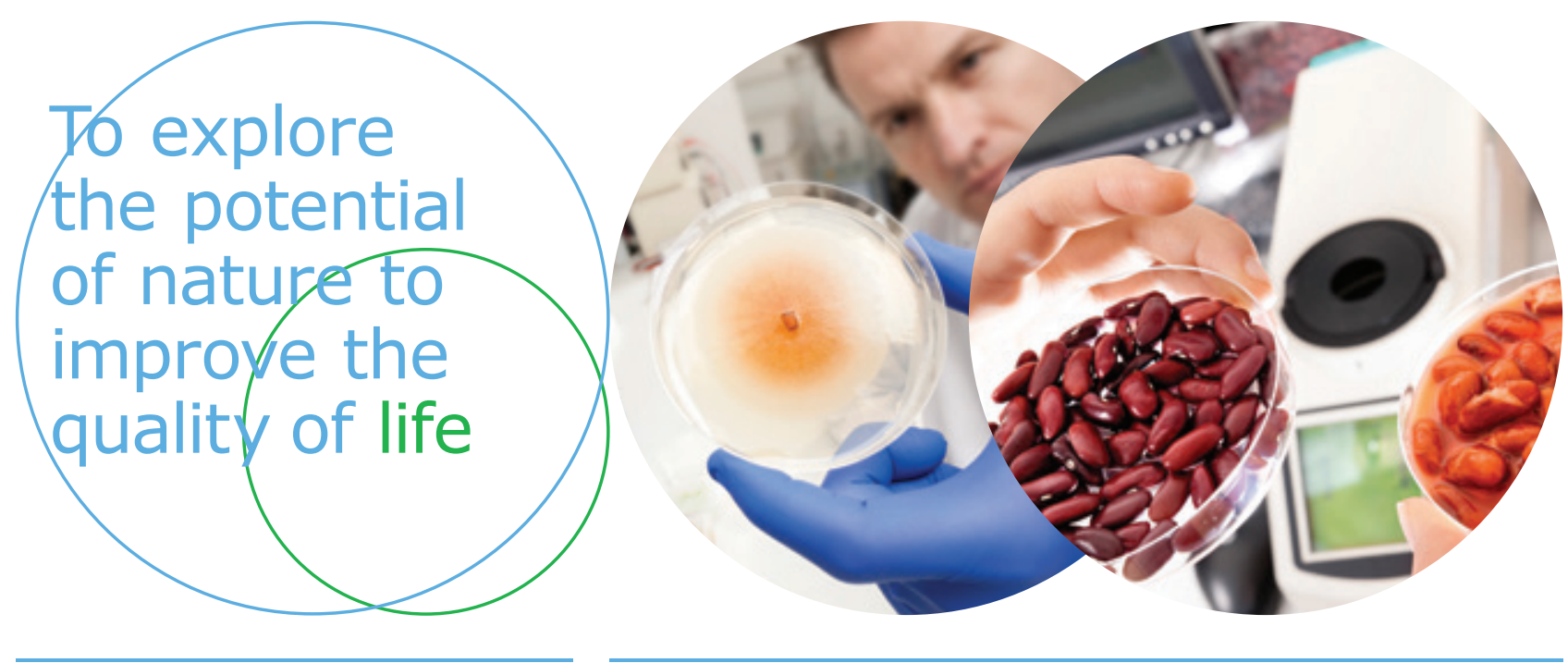

Wageningen Food \& Biobased Research Bornse Weilanden 9

6708 WG Wageningen

www.wur.nl/wfbr

info.wfbr@wur.nl

Rapport 1955

ISBN 978-94-6343-945-9
De missie van Wageningen University \& Research is 'To explore the potential of nature to improve the quality of life'. Binnen Wageningen University \& Research bundelen Wageningen University en gespecialiseerde onderzoeksinstituten van Stichting Wageningen Research hun krachten om bij te dragen aan de oplossing van belangrijke vragen in het domein van gezonde voeding en leefomgeving. Met ongeveer 30 vestigingen, 5.000 medewerkers en 10.000 studenten behoort Wageningen University \& Research wereldwijd tot de aansprekende kennisinstellingen binnen haar domein. De integrale benadering van de vraagstukken en de samenwerking tussen verschillende disciplines vormen het hart van de unieke Wageningen aanpak. 